Prepared in cooperation with the Centers for Disease Control and Prevention

\title{
Summary of Selected U.S. Geological Survey Data on Domestic Well Water Quality for the Centers for Disease Control's National Environmental Public Health Tracking Program
}

Scientific Investigations Report 2007-5213 
This page intentionally left blank. 


\section{Summary of Selected U.S. Geological Survey Data on Domestic Well Water Quality for the Centers for Disease Control's National Environmental Public Health Tracking Program}

By Roy C. Bartholomay, Janet M. Carter, Sharon L. Qi, Paul J. Squillace, and Gary L. Rowe

Prepared in cooperation with the Centers for Disease Control and Prevention

Scientific Investigations Report 2007-5213 


\section{U.S. Department of the Interior DIRK KEMPTHORNE, Secretary}

\section{U.S. Geological Survey \\ Mark D. Myers, Director}

\section{U.S. Geological Survey, Reston, Virginia: 2007}

For product and ordering information:

World Wide Web: http://www.usgs.gov/pubprod

Telephone: 1-888-ASK-USGS

For more information on the USGS--the Federal source for science about the Earth, its natural and living resources, natural hazards, and the environment:

World Wide Web: http://www.usgs.gov

Telephone: 1-888-ASK-USGS

Any use of trade, product, or firm names is for descriptive purposes only and does not imply endorsement by the U.S. Government.

Although this report is in the public domain, permission must be secured from the individual copyright owners to reproduce any copyrighted materials contained within this report.

Suggested citation:

Bartholomay, R.C., Carter, J.M., Qi, S.L., Squillace, P.J., and Rowe, G.L., 2007, Summary of selected U.S Geological Survey data on domestic well water quality for the Centers for Disease Control's National Environmental Public Health Tracking Program: U.S. Geological Survey Scientific Investigations Report 2007-5213, 57 p. 


\section{Contents}

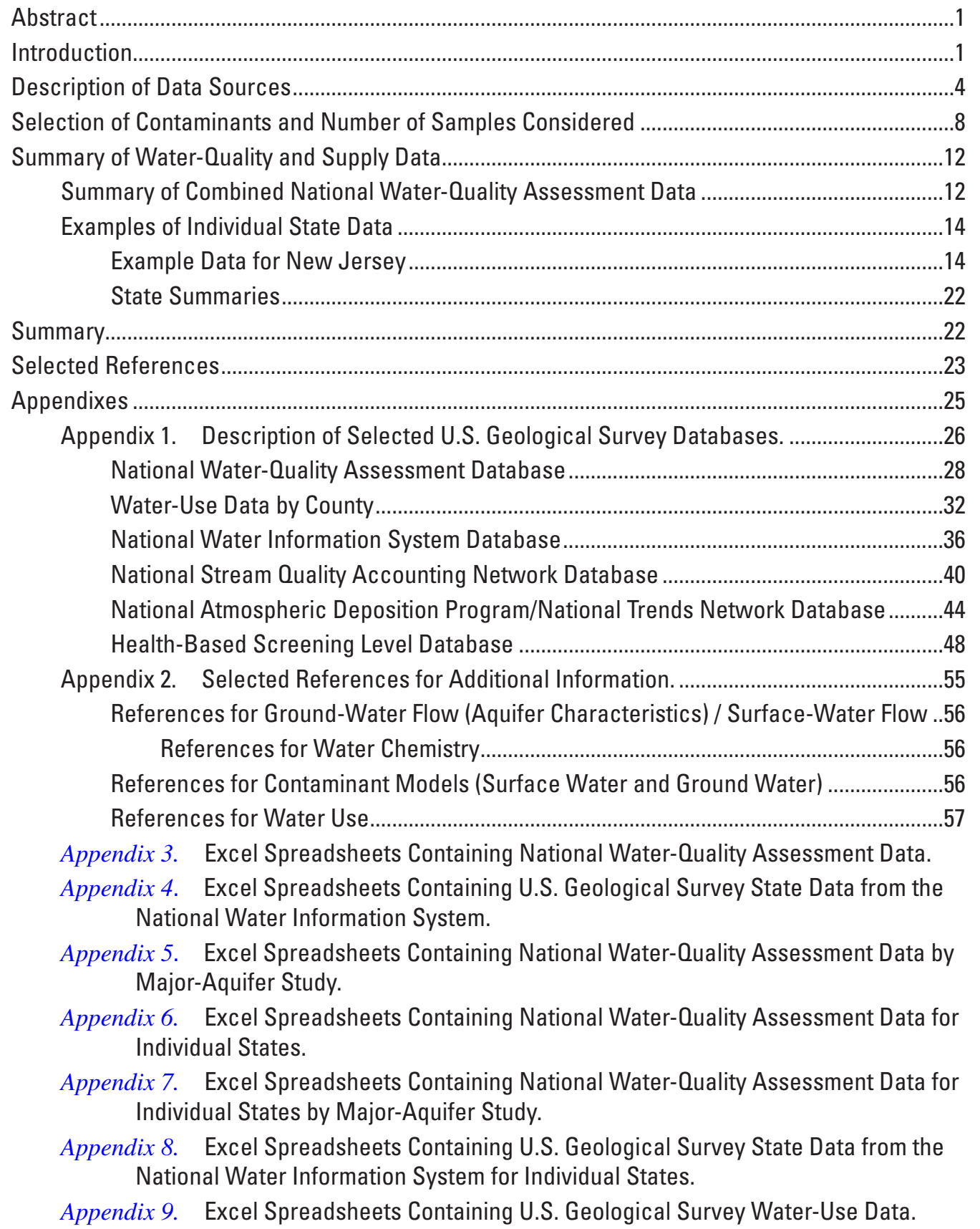




\section{Figures}

1-4. Maps showing:

1. Location of 16 Environmental Public Health Tracking grantee States. .2

2. Maps showing domestic self-supplied population, and domestic self-supplied population as a percentage of total population, in 2000

3. Location of domestic-water supplies sampled by the National Water-Quality Assessment (NAWQA) Program associated with the 16 grantee States with location of principal aquifers.

4. Location of domestic-water supplies in National Water Information System within the 16 grantee States with location of principal aquifers

5. Bar chart showing statistical summary of contaminant concentrations relative to human-health benchmarks in domestic-water supply samples collected by the National Water-Quality Assessment (NAWQA) Program in major-aquifer studies associated with 16 grantee States.

6-11. Maps showing:

6. Population density for New Jersey and nearby States.

7. Population using domestic-water supply for New Jersey.

8. Land use/land cover for New Jersey and nearby States.

9. Location of domestic wells sampled by the National Water-Quality Assessment (NAWQA) Program for major-aquifer studies with principal aquifers that included New Jersey.

10. Statistical summary of nitrate concentrations by major-aquifer study using domestic-well data from National Water-Quality Assessment (NAWOA) studies for New Jersey.

11. Concentration of nitrate in samples from domestic-water supply wells in New Jersey and nearby States.

\section{Tables}

1. Strengths and limitations of National Water-Quality Assessment (NAWQA) data and U.S. Geological Survey (USGS) State data .

2. Contaminants considered and selected for investigation based on their occurrence and concentration relative to U.S. Environmental Protection Agency human-health benchmarks.

3. Contaminants considered and selected for investigation based on their occurrence and concentration relative to U.S. Environmental Protection Agency human-health benchmarks in water from wells sampled for National Water-Quality Assessment (NAWQA) studies.

4. Counts of analyses available from domestic-water supply samples for U.S. Geological Survey State data from the National Water Information System database for the 11 selected contaminants within the 16 grantee States.

5. Statistical summary of the National Water-Quality Assessment data available to define the occurrence and concentrations of contaminants in 16 grantee States using human-health benchmarks defined by U.S. Environmental Protection Agency. 
6. List of spreadsheets created for each grantee State . .14

7. Definition of fields used to describe selected U.S. Geological Survey databases .........27

8. Selected information for the National Water-Quality Assessment database..................29

9. Selected information for the water-use database...........................................................

10. Selected information for the National Water Information System database....................37

11. Selected information for the National Stream Quality Accounting Network database

12. Selected information for the National Atmospheric Deposition Program/National

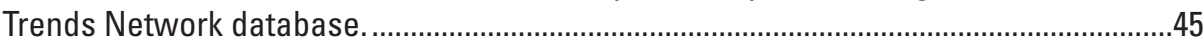

13. Selected information for the Health-Based Screening Level Database.........................49

\section{Conversion Factors and Acronyms}

\begin{tabular}{|c|c|c|}
\hline Multiply & By & To obtain \\
\hline \multicolumn{3}{|c|}{ Length } \\
\hline meter $(\mathrm{m})$ & 3.281 & foot $(\mathrm{ft})$ \\
\hline kilometer $(\mathrm{km})$ & 0.6214 & mile (mi) \\
\hline \multicolumn{3}{|c|}{ Area } \\
\hline square kilometer $\left(\mathrm{km}^{2}\right)$ & 0.3861 & square mile $\left(\mathrm{mi}^{2}\right)$ \\
\hline \multicolumn{3}{|c|}{ Volume } \\
\hline liter (L) & 1.057 & quart $(\mathrm{qt})$ \\
\hline liter $(\mathrm{L})$ & 0.2642 & gallon (gal) \\
\hline cubic meter $\left(\mathrm{m}^{3}\right)$ & 264.2 & gallon (gal) \\
\hline cubic meter $\left(\mathrm{m}^{3}\right)$ & 35.31 & cubic foot $\left(\mathrm{ft}^{3}\right)$ \\
\hline \multicolumn{3}{|c|}{ Flow rate } \\
\hline cubic meter per second $\left(\mathrm{m}^{3} / \mathrm{s}\right)$ & 35.31 & cubic foot per second $\left(\mathrm{ft}^{3} / \mathrm{s}\right)$ \\
\hline cubic meter per second $\left(\mathrm{m}^{3} / \mathrm{s}\right)$ & 22.83 & million gallons per day (Mgal/d) \\
\hline \multicolumn{3}{|r|}{ 等 } \\
\hline $\operatorname{gram}(\mathrm{g})$ & 0.03527 & ounce, avoirdupois (oz) \\
\hline kilogram (kg) & 2.205 & pound avoirdupois (lb) \\
\hline \multicolumn{3}{|c|}{ Radioactivity } \\
\hline becquerel per liter $(\mathrm{Bq} / \mathrm{L})$ & 27.027 & picocurie per liter $(\mathrm{pCi} / \mathrm{L})$ \\
\hline
\end{tabular}

Temperature in degrees Celsius $\left({ }^{\circ} \mathrm{C}\right)$ may be converted to degrees Fahrenheit $\left({ }^{\circ} \mathrm{F}\right)$ as follows:

$$
{ }^{\circ} \mathrm{F}=\left(1.8 \times{ }^{\circ} \mathrm{C}\right)+32
$$

Temperature in degrees Fahrenheit $\left({ }^{\circ} \mathrm{F}\right)$ may be converted to degrees Celsius $\left({ }^{\circ} \mathrm{C}\right)$ as follows:

$$
{ }^{\circ} \mathrm{C}=\left({ }^{\circ} \mathrm{F}-32\right) / 1.8
$$

Horizontal coordinate information is referenced to the North American Datum of 1983 (NAD 83).

Specific conductance is given in microsiemens per centimeter at 25 degrees Celsius $(\mu \mathrm{S} / \mathrm{cm}$ at $\left.25^{\circ} \mathrm{C}\right)$.

Concentrations of chemical constituents in water are given in milligrams per liter $(\mathrm{mg} / \mathrm{L})$, micrograms per liter $(\mu \mathrm{g} / \mathrm{L})$, or picocuries per liter $(\mathrm{pCi} / \mathrm{L})$. 


\section{Acronyms}

$\begin{array}{ll}\mathrm{mg} / \mathrm{L} & \text { milligrams per liter } \\ \mathrm{pCi} / \mathrm{L} & \text { picocuries per liter } \\ \mu \mathrm{g} / \mathrm{L} & \text { micrograms per liter } \\ \mathrm{CDC} & \text { Centers for Disease Control and Prevention } \\ \mathrm{EPHT} & \text { Environmental Public Health Tracking } \\ \mathrm{GIRAS} & \text { geographic information retrieval and analysis system } \\ \mathrm{GIS} & \text { geographic information system } \\ \mathrm{HA} & \text { Health Advisory } \\ \mathrm{MCL} & \text { Maximum Contaminant Level } \\ \text { MCLG } & \text { Maximum Contaminant Level Goal } \\ \text { NAWQA } & \text { National Water-Quality Assessment } \\ \text { NLCD } & \text { National Land Cover Data } \\ \text { NLCDE } & \text { enhanced National Land Cover Data } \\ \text { NWIS } & \text { National Water Information System } \\ \text { USEPA } & \text { U.S. Environmental Protection Agency } \\ \text { USGS } & \text { U.S. Geological Survey } \\ \text { VOC } & \text { volatile organic compound }\end{array}$




\title{
Summary of Selected U.S. Geological Survey Data on Domestic Well Water Quality for the Centers for Disease Control's National Environmental Public Health Tracking Program
}

\author{
By Roy C. Bartholomay, Janet M. Carter, Sharon L. Qi, Paul J. Squillace, and Gary L. Rowe
}

\section{Abstract}

About 10 to 30 percent of the population in most States uses domestic (private) water supply. In many States, the total number of people served by domestic supplies can be in the millions. The water quality of domestic supplies is inconsistently regulated and generally not well characterized. The U.S. Geological Survey (USGS) has two water-quality data sets in the National Water Information System (NWIS) database that can be used to help define the water quality of domestic-water supplies: (1) data from the National WaterQuality Assessment (NAWQA) Program, and (2) USGS State data. Data from domestic wells from the NAWQA Program were collected to meet one of the Program's objectives, which was to define the water quality of major aquifers in the United States. These domestic wells were located primarily in rural areas. Water-quality conditions in these major aquifers as defined by the NAWQA data can be compared because of the consistency of the NAWQA sampling design, sampling protocols, and water-quality analyses. The NWIS database is a repository of USGS water data collected for a variety of projects; consequently, project objectives and analytical methods vary. This variability can bias statistical summaries of contaminant occurrence and concentrations; nevertheless, these data can be used to define the geographic distribution of contaminants. Maps created using NAWQA and USGS State data in NWIS can show geographic areas where contaminant concentrations may be of potential human-health concern by showing concentrations relative to human-health water-quality benchmarks.

On the basis of national summaries of detection frequencies and concentrations relative to U.S. Environmental Protection Agency (USEPA) human-health benchmarks for trace elements, pesticides, and volatile organic compounds, 28 water-quality constituents were identified as contaminants of potential human-health concern. From this list, 11 contaminants were selected for summarization of waterquality data in 16 States (grantee States) that were funded by the Environmental Public Health Tracking (EPHT) Program of the Centers for Disease Control and Prevention (CDC). Only data from domestic-water supplies were used in this summary because samples from these wells are most relevant to human exposure for the targeted population. Using NAWQA data, the concentrations of the 11 contaminants were compared to USEPA human-health benchmarks. Using NAWQA and USGS State data in NWIS, the geographic distribution of the contaminants were mapped for the 16 grantee States. Radon, arsenic, manganese, nitrate, strontium, and uranium had the largest percentages of samples with concentrations greater than their human-health benchmarks. In contrast, organic compounds (pesticides and volatile organic compounds) had the lowest percentages of samples with concentrations greater than human-health benchmarks.

Results of data retrievals and spatial analysis were compiled for each of the 16 States and are presented in State summaries for each State. Example summary tables, graphs, and maps based on USGS data for New Jersey are presented to illustrate how USGS water-quality and associated ancillary geospatial data can be used by the CDC to address goals and objectives of the EPHT Program.

\section{Introduction}

The environment plays an important role in human development and health. Researchers have related exposures to some environmental contaminants with specific diseases; for example, exposure to asbestos has been related to lung cancer (Agency for Toxic Substances and Disease Registry, 2001). Other associations between environmental exposures and health effects are suspected and need additional research; for example, the association between exposure to disinfectant by-products and bladder cancer (Morris, 1995). Few systems currently (2007) exist at the State or national level to track many of the exposures and health effects that may be related to the environment.

The Centers for Disease Control and Prevention's (CDC) National Environmental Public Health Tracking 
(EPHT) Program is providing grants to State and local health departments to develop State EPHT networks to monitor human health, environmental exposures, and contaminants in the environment. The Program's goals are to (1) build a sustainable national environmental public-health tracking network; (2) enhance environmental public-health tracking workforce and infrastructure; (3) disseminate information to guide policy, practice, and other actions to improve the Nation's health; (4) advance environmental public-health science and research; and (5) foster collaboration among health and environmental programs. Currently, most of the 16 States that have received EPHT grants (hereafter referred to as the grantee States) (fig. 1) have begun to include a water-quality component in their tracking work. Among the 16 grantee States, many have reported not having waterquality data for the entire State.

To increase the number of grantee States that include water-quality data in their EPHT networks, CDC is collaborating with the U.S. Geological Survey (USGS) to obtain water data in a format that can be easily used by public-health practitioners. The National Water-Quality Assessment (NAWQA) Program of the USGS has collected and continues to collect surface-water and ground-water data for much of the United States (Gilliom and others, 1995). Other USGS data also are available that can augment NAWQA data; for example, USGS State data from the National Water Information System (NWIS) database, which contains many types of data including site information, time-series (flow, stage, precipitation, and chemical), peak-flow, ground-water, water-quality, and water-use data (U.S. Geological Survey, 1998). The NWIS database is a repository of all USGS water data. USGS water-use data provide information such as the number of people served by public- or domestic-water supplies in a particular county. Thus far, the utility of these USGS data for EPHT has not been assessed. Descriptions of selected USGS databases are provided in Appendix 1.

The U.S. Environmental Protection Agency (USEPA) defines public-water supplies as those that provide water to at least 25 people or have a minimum of 15 service connections (U.S. Environmental Protection Agency, 2005). Domesticwater supplies are defined as those that provide water to less than 25 people or 15 service connections, but typically one well serves only one household. USEPA requires publicwater systems to monitor for and control contaminants in water; however, domestic-water supplies are inconsistently regulated and not regulated at the Federal level. Potential exposure to contaminants in domestic-water supplies is not well characterized. In most States, a greater percentage of the population is dependent on public wells than domestic wells as a drinking-water supply (Zogoroski and others, 2006); nevertheless, 10 to 30 percent of the population in most States uses domestic-water supplies, and the total population supplied by domestic wells can be in the millions in some States (fig. 2; Hutson and others, 2004). USGS water-quality

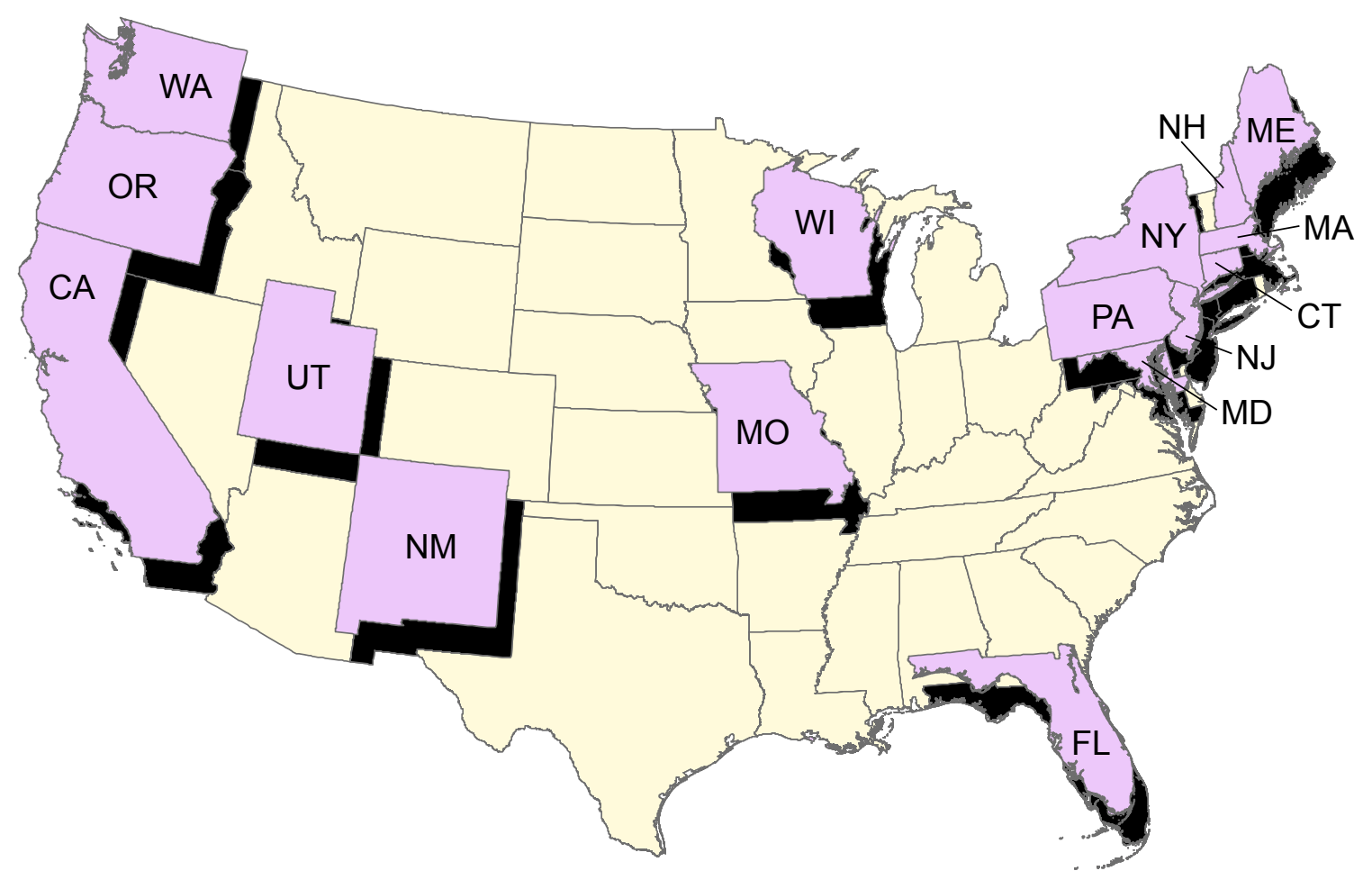

Figure 1. Location of 16 Environmental Public Health Tracking grantee States. 

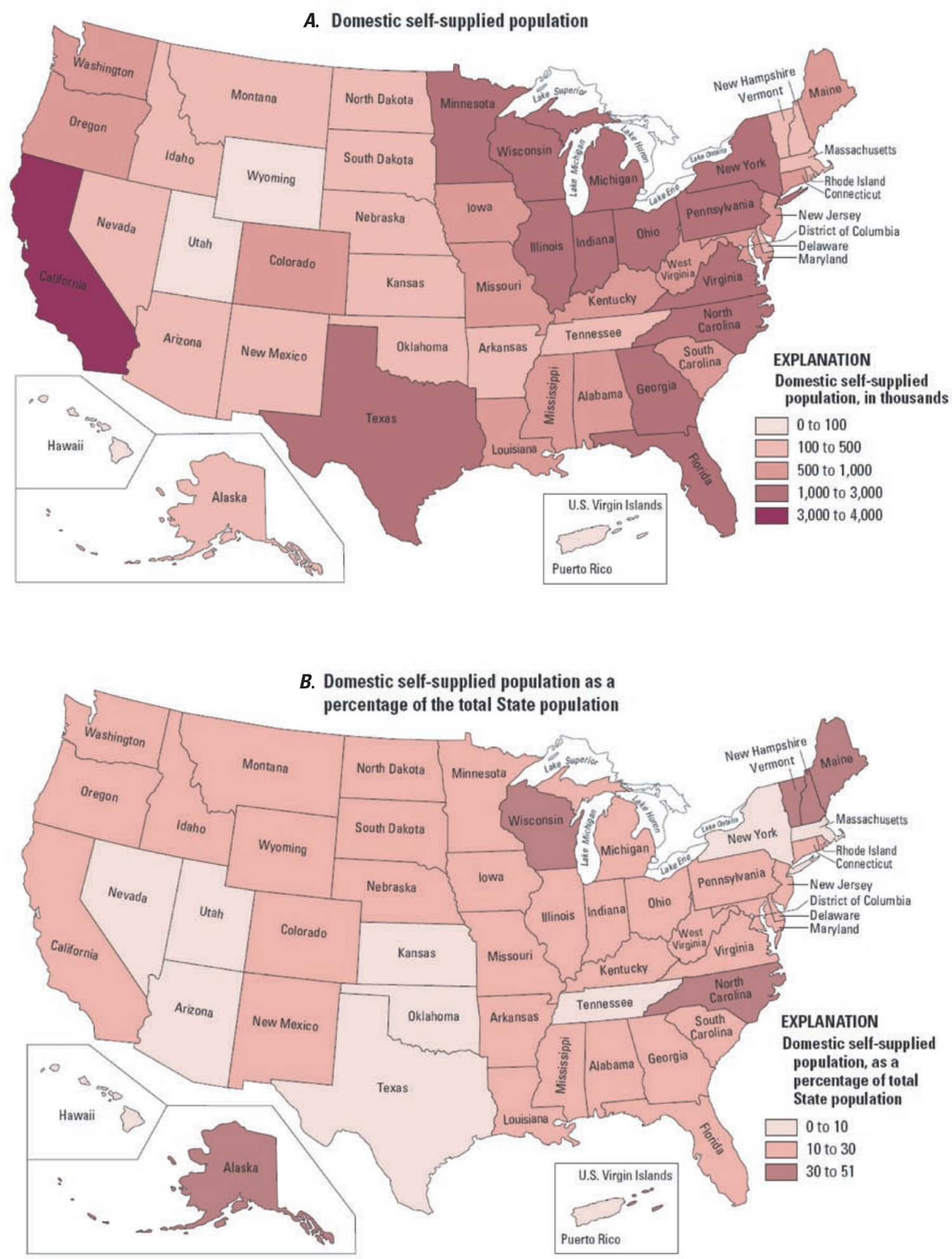

Figure 2. Maps showing (A) domestic self-supplied population, and (B) domestic self-supplied population as a percentage of total population, in 2000 (Hutson and others, 2004). 
data can be used to assess the occurrence and distribution of selected contaminants in individual grantee States and in selected principal aquifers that are used as a source of water to domestic-water supply wells.

This report has four purposes. The first purpose is to provide a description of USGS water-quality and water-use databases that could be helpful to EPHT. The second purpose is to identify water-quality contaminants in water from domestic wells that can be of potential human-health concern for the 16 grantee States. These contaminants were identified by comparing concentrations in USGS databases to humanhealth benchmarks set by USEPA. The third purpose is to provide analyses of water-quality data from domestic-water (private) supplies using data from multiple USGS sources. These data were downloaded from USGS databases in June 2006, and spreadsheets that contain the static data pulled at that time for each of the 16 grantee States are provided in appendixes. The fourth purpose is to summarize and interpret USGS data in a consistent manner so that comparisons among the 16 grantee States are possible. Towards that end, examples of the tables, graphs, and maps produced for New Jersey are included in this report. These examples are accompanied by descriptions of the data that were used to compile these products, and their uses and limitations. State summaries for each of the 16 grantee States are provided and describe results of the water-quality data compilation and analyses relative to EPHT goals and objectives.

Appendix 2 contains a list of references that can be used as a starting point for additional information about groundwater flow (aquifer characteristics)/surface-water flow, water chemistry for States and the Nation, contaminant models, and water use. Additional selected references that provide information specific to water quality in each of the 16 grantee States are included in the State summaries. Locations of Study Units referred to in the report are shown in the State summaries.

\section{Description of Data Sources}

Two USGS water-quality data sources were used for this study: (1) NAWQA data, and (2) USGS State data obtained from the NWIS database. NAWQA data are stored in the NWIS database, but for this study, data referred to as "USGS State data" did not include any of the NAWQA data. USGS State data is defined as water-quality samples collected by the USGS from domestic-water supplies as part of Federal, State, and local studies. The strengths and limitations of each data source are described in table 1, and also are described in detail in Appendix 1. NAWQA and USGS State data do not directly measure exposure or potential effects on human health, but the NAWQA Program provides a foundation or framework for comparing and defining ground-water quality across the Nation. The consistent sampling design, sampling protocols, and water-quality analyses of the NAWQA data allow national-scale comparisons of data (table 1). In contrast, USGS State data were collected for a variety of purposes with variable designs, protocols, and analyses, and may have been collected in areas of known contamination; thus, USGS State data are not necessarily representative of the occurrence of contaminants.

Table 1. Strengths and limitations of National Water-Quality Assessment (NAWQA) data and U.S. Geological Survey (USGS) State data.

\begin{tabular}{|c|c|c|}
\hline Category & NAWOA $^{1}$ & USGS State data \\
\hline Sampling design & $\begin{array}{l}\text { Random stratified sampling of about } 30 \\
\text { wells in a single aquifer study }\end{array}$ & $\begin{array}{l}\text { Variable depending on objectives of study. } \\
\text { Samples for some studies may have been } \\
\text { collected in areas of known contamination. } \\
\text { Data pulled for the summary described } \\
\text { in this report are restricted to domestic } \\
\text { supply wells. }\end{array}$ \\
\hline Sampling protocols & Consistent & Various depending on study type. \\
\hline
\end{tabular}

\footnotetext{
${ }^{1}$ See Gilliom and others (1995) for more information on sampling protocols, analytical methods, and quality control/quality assurance.
} 
Sixty-two principal aquifers have been identified in the United States (U.S. Geological Survey, 2003, http://www. nationalatlas.gov/mld/aquifrp.html), of which 33 were sampled by NAWQA during its first decade of assessments (Zogorski and others, 2006). Principal aquifers define regions where water quality generally is expected to be somewhat similar, so the identification of water quality relative to human-health benchmarks is useful to the CDC. NAWQA major-aquifer studies (also called Study-Unit Surveys) were designed to define the quality of domestic ground-water resources in many of these principal aquifer systems (fig. 3). As such, these studies probably are most relevant to human health for rural areas of the Nation where untreated ground water is used as a source of drinking water.

Major-aquifer studies have three important characteristics. First, samples were collected before any treatment to define the quality of water in the aquifer. Second, sampled wells were spatially distributed and randomly selected among existing wells within the aquifer so these should be representative of overall water quality. Third, most of the samples were collected from domestic wells (one well that provides water to one home) in rural areas of the Nation. As such, these studies probably are most relevant to human health for rural areas of the Nation where untreated ground water is used as a source of drinking water.

For this study, only samples from domestic-water supplies were compiled. Almost all water samples collected by NAWQA were analyzed for dissolved constituents of nutrients, trace elements, pesticides, and volatile organic compounds (VOCs). Drinking-water standards established by the USEPA are based on total constituent concentrations, which refer to the combined concentrations of both dissolved and suspended phases of the water sample. Results reported by the USGS as dissolved constituent concentrations may be less than those obtained from similar samples analyzed for total constituent concentrations; thus, concentrations greater than human-health benchmarks could be underestimated. Statistical summaries of NAWQA major-aquifer studies provide a description of the overall water quality of the study area, and comparisons can be made between aquifer studies based on these summaries. The locations of water-quality samples collected by USGS from domestic-water supplies as part of NAWQA studies within the 16 grantee States are shown on figure 3. Analytical results of 1,452 samples from 1,098 domestic wells were available.

The locations of water-quality samples collected by USGS from domestic-water supplies as part of Federal, State, and local studies (USGS State data) within the 16 grantee States are shown in figure 4 . Analytical results of $(18,407)$ samples from 12,708 domestic wells were available for the 16 grantee States. The NWIS database stores a complex set of data that has been collected for a variety of projects ranging from national programs to studies in small watersheds using a variety of sampling protocols and analytical methods; consequently, variability in these factors can strongly influence statistical summaries of collected data. Because of this variability and potential bias due to collection of some samples in areas of known contamination, statistical summaries of USGS State data are not provided. USGS State data were used to provide additional information in areas where NAWQA samples were sparse. Most USGS State data are available on the Web at http://waterdata.usgs.gov/nwis/qw.

Three geographic information system (GIS) data sets were prepared for this study to help define the environmental settings where data were collected. First, a data set of population density was prepared because these data can be associated with certain types of anthropogenic contamination if use and release to the environment increases with population; for example, some solvents and gasoline. Population density by census block group was obtained for the United States using the 2000 Census of Population and Housing (Hitt, 2003).

Second, a data set of land use/land cover was prepared because these data also can be associated with certain types of anthropogenic contamination. Some pesticides can, for example, be associated with agricultural land use; in contrast, aquifers underlying forest and barren land can have some of the cleanest ground water. Land use/land cover was from the "enhanced" National Land Cover Data (NLCDE) developed for a national-scale analysis of NAWQA data using ancillary information from USGS historical land-use and land-cover (geographic information retrieval and analysis system, or "GIRAS") data (Price and others, 2003; 2006) to modify the 1992 National Land Cover Data (NLCD) (U.S. Geological Survey, 1992). The 1990 and 2000 population densities (by census block group) also were used to identify recent (2000) urban development for NLCDE. Within each 1-kilometer grid, the land-cover class with the highest percentage was selected for use in the final land-cover grid.

Third, a data set of population using domestic-water supplies, at the 1990 census block group level, was prepared because these data help link a contaminant in the aquifer to human exposure. The USGS also has compiled and published national water-use estimates, at the State level, every 5 years since 1950, and this series of water-use reports serves as one of the few sources of information about regional or national trends in water withdrawals. These water-use data do not estimate consumption from domestic-water supplies or document the presence or absence of a home water purification system; nevertheless, these data can provide some information about potential human exposure. Data files for the most recent compilation (2000) by county for all States in the Nation are located at http://water.usgs.gov/watuse/data/2000/ index.html. Additional information about USGS water-use data is presented in Appendix 1. 


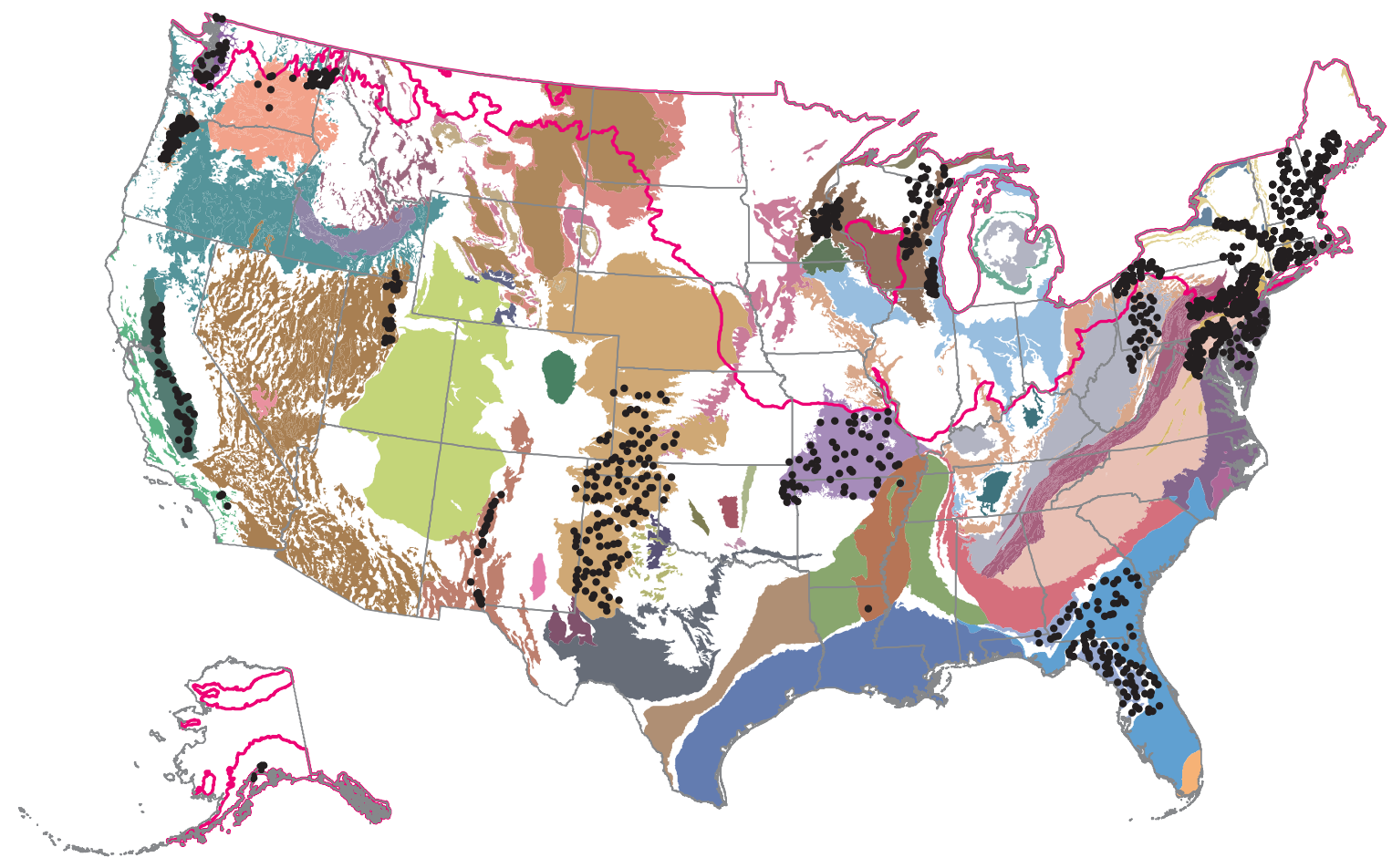

EXPLANATION

- Domestic wells sampled by NAWQA

Extent of Glacial aquifers

\section{Principal aquifers}

- Basin and Range basin-fill aquifers

Basin and Range carbonate-rock aquifers

Biscayne aquifer

California Coastal Basin aquifers

- Cambrian-Ordovician aquifer system

- Central Valley aquifer system

Coastal lowlands aquifer system

Colorado Plateaus aquifers

Columbia Plateau basaltic-rock aquifers

Columbia Plateau basin-fill aquifers

Denver Basin aquifer system

Early Mesozoic basin aquifers
Edwards-Trinity aquifer system

- Floridan aquifer system

- High Plains aquifer

Lower Cretaceous aquifers

Lower Tertiary aquifers

Marshall aquifer

Mississippi River Valley alluvial aquifer

Mississippi embayment aquifer system

Mississippian aquifers

New York and New England carbonate-rock aquifers

- Northern Atlantic Coastal Plain aquifer system

- Northern Rocky Mountains Intermontane Basins aquifer system

Ozark Plateaus aquifer system

Pacific Northwest basaltic-rock aquifers

- Pacific Northwest basin-fill aquifers

Paleozoic aquifers
Pennsylvanian aquifers

- Piedmont and Blue Ridge carbonate-rock aquifers

- Piedmont and Blue Ridge crystalline-rock aquifers

- Puget Sound aquifer system

Rio Grande aquifer system

Silurian-Devonian aquifers

- Snake River Plain basaltic-rock aquifers

- Snake River Plain basin-fill aquifers

Southeastern Coastal Plain aquifer system

- Surficial aquifer system

- Texas coastal uplands aquifer system

Upper Cretaceous aquifers

Valley and Ridge aquifers

- Valley and Ridge carbonate-rock aquifers

Willamette Lowland basin-fill aquifers

Figure 3. Location of domestic-water supplies sampled $(n=1,098)$ by the National Water-Quality Assessment (NAWQA) Program associated with the 16 grantee States (figure 1) with location of principal aquifers. 


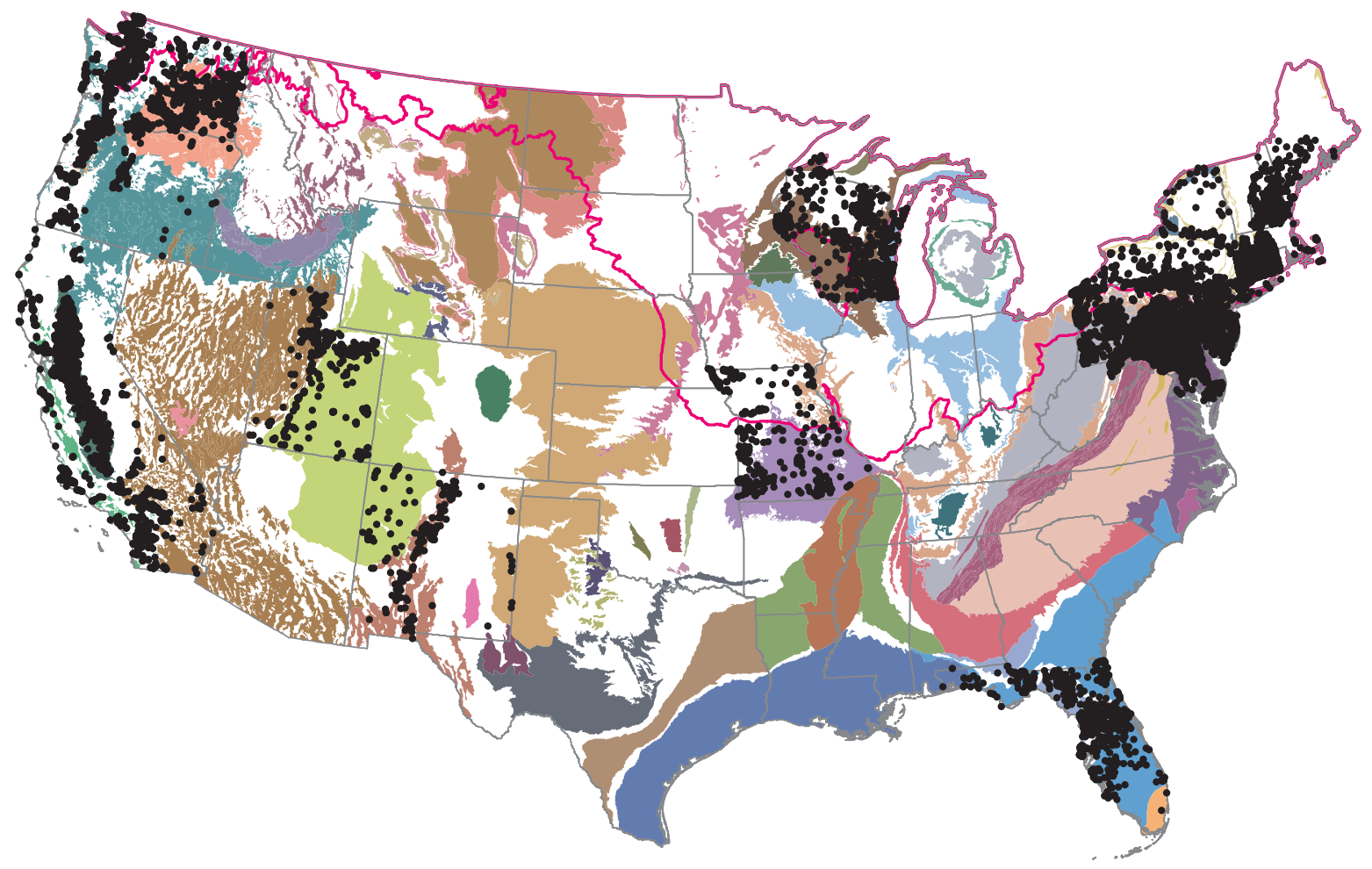

EXPLANATION

- Domestic wells in NWIS data base

Extent of Glacial aquifers

\section{Principal aquifers}

Basin and Range basin-fill aquifers

Basin and Range carbonate-rock aquifers

- Biscayne aquifer

California Coastal Basin aquifers

- Cambrian-Ordovician aquifer system

Central Valley aquifer system

- Coastal lowlands aquifer system

Colorado Plateaus aquifers

Columbia Plateau basaltic-rock aquifers

Columbia Plateau basin-fill aquifers

Denver Basin aquifer system

Early Mesozoic basin aquifers

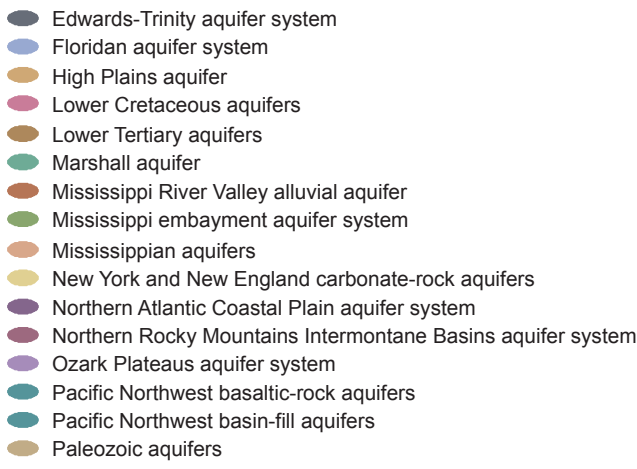

Pennsylvanian aquifers

Piedmont and Blue Ridge carbonate-rock aquifers

- Piedmont and Blue Ridge crystalline-rock aquifers

- Puget Sound aquifer system

Rio Grande aquifer system

Silurian-Devonian aquifers

- Snake River Plain basaltic-rock aquifers

- Snake River Plain basin-fill aquifers

- Southeastern Coastal Plain aquifer system

- Surficial aquifer system

- Texas coastal uplands aquifer system

Upper Cretaceous aquifers

- Valley and Ridge aquifers

- Valley and Ridge carbonate-rock aquifers

Willamette Lowland basin-fill aquifers

Figure 4. Location of domestic-water supplies in National Water Information System $(n=12,708)$ within the 16 grantee States (figure 1) with location of principal aquifers. 


\section{Selection of Contaminants and Number of Samples Considered}

On the basis of national summaries of detection frequencies and concentrations relative to USEPA humanhealth benchmarks for trace elements, pesticides, and VOCs, 28 water-quality constituents were identified as contaminants of potential human-health concern. These 28 contaminants included nutrients, trace elements, pesticides, and VOCs (table 2). Of these 28 contaminants, 11 were selected for additional consideration (table 2). These 11 contaminants were selected because they (1) represent a mix of nutrients, trace elements, pesticides, and VOCs, (2) were among the contaminants with the largest detection frequencies or concentrations, and (3) were identified (by USGS in consultation with $\mathrm{CDC}$ ) as potentially important contaminants to human health according to recent research.

Summary statistics of the occurrence and concentrations of these 11 contaminants were calculated for the 16 grantee States. Contaminant concentrations were compared to human-health benchmarks set by the USEPA to provide an initial national-scale perspective on the potential relevance to human health. The human-health benchmarks used in this screening-level assessment include USEPA Maximum Contaminant Level Goals (MCLGs), Maximum Contaminant Levels (MCLs), and Lifetime Health Advisories (HAs) (table 2; U.S. Environmental Protection Agency, 2006). Concentrations of regulated contaminants were compared to MCLs, and concentrations of unregulated contaminants were compared to HAs, when available. A human-health benchmark has not been established for deethylatrazine, which is a degradate of atrazine. In risk assessments of atrazine, the toxicity of atrazine and its chlorinated metabolites, such as deethylatrazine, are considered equivalent (U.S. Environmental Protection Agency, 2003); therefore, the risks associated with exposure to deethylatrazine are considered equivalent to exposure to atrazine. For purposes in this report, concentrations of deethylatrazine were compared to the human-health benchmark for atrazine. Generally, USGS data for nitrate consists of analyses for nitrite plus nitrate by the laboratory. In almost all environmental samples, nitrite is a very small (less than the reporting level) fraction of the reported concentration, so concentrations of nitrate make up most of the total concentration; consequently, nitrite plus nitrate concentrations will be referred to as nitrate for comparison to the MCL for nitrate in this report.

For the 16 grantee States, the number of analytical results available for the 11 selected contaminants in domestic-water supply samples are presented in table 3 for NAWQA data (based on the most recent analysis per well) and in table 4 for USGS State data (based on all available analyses including multiple samples per well). The areal extent of some NAWQA major-aquifer studies can go beyond the State boundary for a particular grantee State. In these situations, all data associated with a major-aquifer study are provided even if the sampled well was located outside the State boundary. For USGS State data, the analytical results are provided for samples from all wells identified as domestic wells located within the State boundary for each State grantee. Some water-quality data could be missing if the wells were not properly identified as domestic wells in the database. The numbers of samples for each of the 11 contaminants generally were larger for USGS State data than NAWQA data. 
Table 2. Contaminants considered and selected for investigation based on their occurrence and concentration relative to U.S. Environmental Protection Agency human-health benchmarks.

[HA, Lifetime Health Advisory; MCLG, Maximum Contaminant Level Goal; MCL, Maximum Contaminant Level; VOC, volatile organic compound; $\mu \mathrm{g} / \mathrm{L}$, micrograms per liter; mg/L, milligrams per liter; $\mathrm{pCi} / \mathrm{L}$, picocuries per liter; --, not applicable]

\begin{tabular}{|c|c|c|c|c|c|}
\hline \multirow{2}{*}{$\begin{array}{l}\text { Initial } 28 \text { contaminants } \\
\text { based on national-scale } \\
\text { statistical summaries } \\
\text { of occurrence and } \\
\text { concentrations }\end{array}$} & \multirow{2}{*}{$\begin{array}{l}\text { Contaminant } \\
\text { group }\end{array}$} & \multirow{2}{*}{$\begin{array}{l}11 \text { Contaminants } \\
\text { selected for } \\
\text { consideration in } \\
16 \text { grantee States }\end{array}$} & \multicolumn{3}{|c|}{ U.S. Environmental Protection Agency human-health benchmark ${ }^{1}$} \\
\hline & & & HA & MCLG & MCL \\
\hline Arsenic & Trace element & Yes & -- & 0 & $10 \mu \mathrm{g} / \mathrm{L}$ \\
\hline Atrazine & Pesticide & Yes & -- & $3 \mu \mathrm{g} / \mathrm{L}$ & $3 \mu \mathrm{g} / \mathrm{L}$ \\
\hline Benzene & VOC & Yes & -- & 0 & $5 \mu \mathrm{g} / \mathrm{L}$ \\
\hline Bromodichloromethane & VOC & -- & -- & 0 & $80 \mu \mathrm{g} / \mathrm{L}^{2}$ \\
\hline Bromoform & VOC & -- & -- & 0 & $80 \mu \mathrm{g} / \mathrm{L}^{2}$ \\
\hline Chlorodibromomethane & VOC & -- & -- & $60 \mu \mathrm{g} / \mathrm{L}$ & $80 \mu \mathrm{g} / \mathrm{L}^{2}$ \\
\hline Chloroform & VOC & -- & -- & 0 & $80 \mu \mathrm{g} / \mathrm{L}^{2}$ \\
\hline Chloromethane & VOC & -- & $30 \mu \mathrm{g} / \mathrm{L}$ & -- & -- \\
\hline Chromium & Trace element & -- & -- & $100 \mu \mathrm{g} / \mathrm{L}$ & $100 \mu \mathrm{g} / \mathrm{L}$ \\
\hline Copper & Trace element & -- & -- & $1,300 \mu \mathrm{g} / \mathrm{L}$ & $1,300 \mu \mathrm{g} / \mathrm{L}$ \\
\hline Deethylatrazine (CIAT) ${ }^{3}$ & Pesticide & Yes & -- & $3 \mu \mathrm{g} / \mathrm{L}^{3}$ & $3 \mu \mathrm{g} / \mathrm{L}^{3}$ \\
\hline Dibromochloropropane & VOC & -- & -- & 0 & $0.2 \mu \mathrm{g} / \mathrm{L}$ \\
\hline Ethylenedibromide & VOC & -- & -- & 0 & $0.05 \mu \mathrm{g} / \mathrm{L}$ \\
\hline Lead & Trace element & -- & -- & 0 & $\begin{array}{c}0 \\
\text { action level }=15 \mu \mathrm{g} / \mathrm{L}\end{array}$ \\
\hline Manganese & Trace element & Yes & $300 \mu \mathrm{g} / \mathrm{L}$ & -- & -- \\
\hline Methylene chloride & VOC & -- & -- & 0 & $5 \mu \mathrm{g} / \mathrm{L}$ \\
\hline Metolachlor & Pesticide & -- & $100 \mu \mathrm{g} / \mathrm{L}$ & -- & -- \\
\hline Nitrite plus nitrate-nitrogen & Nutrient & Yes & -- & $10 \mathrm{mg} / \mathrm{L}$ as $\mathrm{N}$ & $10 \mathrm{mg} / \mathrm{L}$ as $\mathrm{N}$ \\
\hline Radon & Radionuclide & Yes & & 0 (proposed) & $\begin{array}{c}300 \mathrm{pCi} / \mathrm{L} \text { or } \\
\text { alternatively } 4,000 \\
\mathrm{pCi} / \mathrm{L} \text { (proposed) }\end{array}$ \\
\hline Strontium & Radionuclide & Yes & $4,000 \mu \mathrm{g} / \mathrm{L}$ & -- & -- \\
\hline $\begin{array}{l}\text { Perchloroethene (tetrachlo- } \\
\text { roethene, PCE) }\end{array}$ & VOC & Yes & -- & 0 & $5 \mu \mathrm{g} / \mathrm{L}$ \\
\hline Prometon & Pesticide & -- & -- & -- & -- \\
\hline Simazine & Pesticide & -- & -- & $4 \mu \mathrm{g} / \mathrm{L}$ & $4 \mu \mathrm{g} / \mathrm{L}$ \\
\hline Toluene & VOC & -- & -- & $1,000 \mu \mathrm{g} / \mathrm{L}$ & $1,000 \mu \mathrm{g} / \mathrm{L}$ \\
\hline 1,1,1-Trichloroethane & VOC & -- & -- & $200 \mu \mathrm{g} / \mathrm{L}$ & $200 \mu \mathrm{g} / \mathrm{L}$ \\
\hline Trichloroethene (TCE) & VOC & Yes & -- & 0 & $5 \mu \mathrm{g} / \mathrm{L}$ \\
\hline 1,2,4-Trimethylbenzene & VOC & -- & -- & -- & -- \\
\hline Uranium & Radionuclide & Yes & -- & 0 & $30 \mu \mathrm{g} / \mathrm{L}$ \\
\hline
\end{tabular}

${ }^{1}$ From U.S. Environmental Protection Agency (2006).

${ }^{2}$ The MCL for bromodichloromethane, bromoform, chlorodibromomethane, and chloroform is the sum of the constituents for all four compounds.

${ }^{3} \mathrm{~A}$ human-health benchmark has not been established for deethylatrazine, which is a degradate of atrazine. For purposes in this report, concentrations of deethylatrazine were compared to the human-health benchmark of 3 micrograms per liter for atrazine. 
Table 3. Contaminants considered and selected for investigation based on their occurrence and concentration relative to U.S. Environmental Protection Agency human-health benchmarks in water from wells sampled for National Water-Quality Assessment (NAWQA) studies.

[Counts include only the most recent analysis per well. First number includes counts of all wells sampled for NAWQA major-aquifer studies that are entirely or partially within each State; number in parenthesis is number of wells within each State's border]

\begin{tabular}{|c|c|c|c|c|c|c|c|c|c|c|c|}
\hline Grantee State & Arsenic & Atrazine & Benzene & $\begin{array}{l}\text { Deethyl- } \\
\text { atrazine } \\
\text { (CIAT) }\end{array}$ & $\begin{array}{l}\text { Mang- } \\
\text { anese }\end{array}$ & Nitrate & $\begin{array}{l}\text { Perchloro- } \\
\text { ethene } \\
\text { (PCE) }\end{array}$ & Radon & Strontium & $\begin{array}{c}\text { Trichloro- } \\
\text { ethene } \\
\text { (TCE) }\end{array}$ & Uranium \\
\hline California & $59(59)$ & $59(59)$ & $59(59)$ & $59(59)$ & $59(59)$ & $58(58)$ & $59(59)$ & $58(58)$ & $30(30)$ & $59(59)$ & $32(32)$ \\
\hline Connecticut & $54(24)$ & $55(24)$ & $55(24)$ & $55(24)$ & $55(24)$ & $55(24)$ & $55(24)$ & $54(23)$ & $28(11)$ & $55(24)$ & $55(24)$ \\
\hline Florida & $89(63)$ & $98(59)$ & $98(59)$ & $98(59)$ & $102(63)$ & $102(63)$ & $98(59)$ & $90(52)$ & $89(63)$ & $98(59)$ & $89(63)$ \\
\hline Maine & $58(36)$ & $56(34)$ & $58(36)$ & $56(34)$ & $58(36)$ & $58(36)$ & $58(36)$ & $54(32)$ & $58(36)$ & $58(36)$ & $58(36)$ \\
\hline Maryland & $29(18)$ & $120(38)$ & $58(19)$ & $123(38)$ & 121(37) & $126(38)$ & $61(20)$ & 113(34) & $51(23)$ & $63(20)$ & $124(38)$ \\
\hline Massachusetts & $84(15)$ & $85(16)$ & $85(16)$ & $85(16)$ & $85(16)$ & $85(16)$ & $85(16)$ & $82(16)$ & $58(10)$ & $85(16)$ & $85(16)$ \\
\hline Missouri & $55(37)$ & $61(37)$ & 51(30) & 61(37) & 61(37) & $61(37)$ & $51(30)$ & $45(29)$ & $0(0)$ & $51(30)$ & $55(37)$ \\
\hline New Hampshire & $112(26)$ & 111(26) & $113(26)$ & 111(26) & $113(26)$ & $113(26)$ & $113(26)$ & $108(26)$ & $86(23)$ & $113(26)$ & $113(26)$ \\
\hline New Jersey & 161(93) & 159(92) & 161(93) & 159(92) & 161(93) & 161(93) & 161(93) & 107(40) & $63(14)$ & 161(93) & $113(45)$ \\
\hline New Mexico & $144(32)$ & $144(31)$ & $143(31)$ & $144(31)$ & $144(32)$ & $145(32)$ & $143(31)$ & $142(31)$ & $45(6)$ & $143(31)$ & $144(32)$ \\
\hline New York & 67(9) & $98(23)$ & $98(23)$ & $98(23)$ & $98(23)$ & $98(23)$ & $98(23)$ & $96(22)$ & $12(6)$ & $98(23)$ & $68(9)$ \\
\hline Oregon & $66(66)$ & $65(65)$ & 61(61) & $65(65)$ & $66(66)$ & $66(66)$ & $61(61)$ & 49(49) & $25(25)$ & $61(61)$ & $36(36)$ \\
\hline Pennsylvania & $110(72)$ & 205(132) & $169(116)$ & $208(135)$ & 209(136) & 214(139) & 172(118) & 203(131) & $82(49)$ & $174(120)$ & $182(121)$ \\
\hline Utah & $32(29)$ & $33(30)$ & $32(29)$ & $33(30)$ & $33(30)$ & $33(30)$ & $32(29)$ & $32(29)$ & 3(3) & $32(29)$ & 32(29) \\
\hline Washington & 29(12) & $58(41)$ & $58(41)$ & $58(41)$ & $58(41)$ & $58(41)$ & $58(41)$ & $58(41)$ & $0(0)$ & $58(41)$ & $29(12)$ \\
\hline Wisconsin & $120(66)$ & 123(69) & 123(69) & 123(69) & 123(69) & 122(69) & 123(69) & 120(69) & $70(51)$ & 123(69) & $120(66)$ \\
\hline Total & $1,269(657)$ & $1,530(776)$ & $1,422(732)$ & $1,536(779)$ & $1,546(788)$ & $1,555(791)$ & $1,428(735)$ & $1,411(682)$ & $700(350)$ & $1,432(737)$ & $1,335(622)$ \\
\hline
\end{tabular}


Table 4. Counts of analyses available from domestic-water supply samples for U.S. Geological Survey State data from the National Water Information System database for the 11 selected contaminants within the 16 grantee States.

[First number includes counts of all samples including multiple samples from wells; number in parenthesis is number of wells with available analyses]

\begin{tabular}{|c|c|c|c|c|c|c|c|c|c|c|c|}
\hline Grantee State & Arsenic & Atrazine & Benzene & $\begin{array}{l}\text { Deethyl- } \\
\text { atrazine } \\
\text { (CIAT) }\end{array}$ & Manganese & Nitrate & $\begin{array}{l}\text { Perchloro- } \\
\text { ethene (PCE) }\end{array}$ & Radon & Strontium & $\begin{array}{c}\text { Trichloro- } \\
\text { ethene (TCE) }\end{array}$ & Uranium \\
\hline California & $1,555(1,075)$ & $59(58)$ & $227(168)$ & $59(58)$ & $2,544(1,386)$ & $3,056(1,216)$ & $227(168)$ & $34(30)$ & $392(322)$ & $225(167)$ & $25(17)$ \\
\hline Connecticut & $11(10)$ & $1(1)$ & 1(1) & $1(1)$ & $762(723)$ & $4(3)$ & $1(1)$ & $29(15)$ & $30(28)$ & $1(1)$ & $121(121)$ \\
\hline Florida & $45(34)$ & $2(2)$ & 11(9) & $2(2)$ & 117(89) & $287(251)$ & $11(9)$ & 27(9) & $592(381)$ & $11(9)$ & 2(2) \\
\hline Maine & $9(6)$ & $0(0)$ & $0(0)$ & $0(0)$ & 4(3) & $29(25)$ & $0(0)$ & $0(0)$ & $0(0)$ & $0(0)$ & $1(1)$ \\
\hline Maryland & $210(203)$ & $242(175)$ & $210(160)$ & $242(175)$ & $744(588)$ & $794(467)$ & $124(124)$ & $358(294)$ & 131(121) & $124(124)$ & $59(58)$ \\
\hline Massachusetts & 88(85) & 1(1) & 1(1) & $1(1)$ & 77(76) & 78(77) & 1(1) & $0(0)$ & 1(1) & 1(1) & 2(2) \\
\hline Missouri & $58(40)$ & 203(93) & $36(28)$ & 203(93) & $132(102)$ & $416(187)$ & $37(29)$ & $0(0)$ & 103(79) & $37(29)$ & $3(3)$ \\
\hline New Hampshire & 16(16) & $0(0)$ & $33(27)$ & $0(0)$ & 17(17) & 3(3) & $33(27)$ & $246(227)$ & $16(16)$ & $33(27)$ & $2(2)$ \\
\hline New Jersey & $366(320)$ & $57(32)$ & $185(165)$ & $20(20)$ & $708(591)$ & $702(551)$ & 131(112) & $166(145)$ & 451(396) & 128(109) & 116(109) \\
\hline New Mexico & $178(135)$ & 3(3) & $6(6)$ & 3(3) & $337(259)$ & $466(279)$ & $6(6)$ & $0(0)$ & $26(23)$ & $6(6)$ & $22(21)$ \\
\hline New York & $60(31)$ & $105(57)$ & $63(59)$ & $105(57)$ & 264(197) & 201(160) & $63(59)$ & $62(60)$ & $16(16)$ & $68(60)$ & $4(4)$ \\
\hline Oregon & $175(163)$ & $0(0)$ & $0(0)$ & $0(0)$ & $263(254)$ & $270(262)$ & $0(0)$ & $0(0)$ & $18(18)$ & $0(0)$ & $3(3)$ \\
\hline Pennsylvania & $1,080(1,030)$ & $335(289)$ & $475(432)$ & $279(257)$ & $2,930(2,646)$ & $1,769(1,434)$ & $421(378)$ & $1,027(875)$ & $360(347)$ & $421(378)$ & $351(332)$ \\
\hline Utah & $127(117)$ & $5(5)$ & $10(10)$ & $5(5)$ & $601(377)$ & $627(399)$ & $10(10)$ & $0(0)$ & $83(66)$ & $10(10)$ & 12(10) \\
\hline Washington & $641(605)$ & $12(12)$ & 117(107) & $12(12)$ & $2,153(1,995)$ & $2,486(1,995)$ & $154(115)$ & $92(88)$ & $390(373)$ & $147(115)$ & 2(2) \\
\hline Wisconsin & 149(147) & $8(8)$ & $10(7)$ & $8(8)$ & 797(720) & $826(765)$ & $10(7)$ & 26(19) & $217(216)$ & $10(7)$ & $8(7)$ \\
\hline Total & $4,768(4,017)$ & $1,033(736)$ & $1,385(1,180)$ & $940(692)$ & $12,450(9,751)$ & $12,014(8,074)$ & $1,229(1,046)$ & $2,067(1,762)$ & $2,826(2,403)$ & $1,222(1,043)$ & 733(694) \\
\hline
\end{tabular}




\section{Summary of Water-Quality and Supply Data}

NAWQA data and USGS State data retrieved from USGS databases for domestic-water supply samples were aggregated in three different ways. First, NAWQA and USGS State waterquality data for the 11 selected contaminants were compiled into two spreadsheets for all 16 grantee States (Appendixes 3 and 4, respectively). Second, NAWQA data from 38 majoraquifer studies were summarized so that occurrence of the 11 contaminants in a specific aquifer could be compared to other aquifers (Appendix 5).

Third, available water-quality data were aggregated on a State by State basis for the 16 grantee States for NAWQA data (Appendix 6), NAWQA data by major-aquifer study (Appendix 7), and USGS State data in the NWIS database (Appendix 8). A consistent set of summary data tables, graphs, and maps were developed to examine the occurrence and concentrations of the 11 selected contaminants in a particular grantee State as a function of principal aquifer, major-aquifer study, domestic water use, population density, and land-use/land-cover. Example data tables, graphs, and maps are described in the "Examples of Individual State Data" section. The available data, results of the statistical and spatial analyses, and associations between contaminants and key environmental factors are described in a State summary for each of the 16 grantee States.

The NAWQA data were summarized to provide an overall perspective on the occurrence and concentrations of the 11 contaminants for the 16 grantee States. As previously stated, statistical summaries of USGS State data, which may include multiple analyses per well, are not provided because of the variability in sampling and analytical protocols and potential bias due to collection of some samples in areas of known contamination.

\section{Summary of Combined National Water-Quality Assessment Data}

A statistical summary of the NAWQA data based on the most recent analysis per well for each of the 11 selected contaminants is presented in table 5. This table includes the number of wells sampled, detection frequencies, and concentrations relative to human-health benchmarks set by the USEPA. These data were compiled from 38 major-aquifer studies associated with the 16 grantee States. The number of NAWQA samples for a particular contaminant is larger in table 3 than in table 5 because some samples in table 3

Table 5. Statistical summary of the National Water-Quality Assessment data available to define the occurrence and concentrations of contaminants in 16 grantee States using human-health benchmarks defined by U.S. Environmental Protection Agency.

[MCL, Maximum Contaminant Level; HA, Lifetime Health Advisory; $\mu \mathrm{g} / \mathrm{L}$, micrograms per liter; mg/L, milligrams per liter; pCi/L, picocuries per liter]

\begin{tabular}{|c|c|c|c|c|c|c|c|}
\hline Contaminant & $\begin{array}{l}\text { Number } \\
\text { of wells } \\
\text { sampled }\end{array}$ & $\begin{array}{l}\text { Common } \\
\text { assessment } \\
\text { level used } \\
\text { for detection } \\
\text { frequency }\end{array}$ & $\begin{array}{c}\text { Detection } \\
\text { frequency } \\
\text { (percent) }\end{array}$ & $\begin{array}{c}\text { Bench- } \\
\text { mark } \\
\text { type }\end{array}$ & $\begin{array}{c}\text { Benchmark } \\
\text { concentration' }\end{array}$ & $\begin{array}{l}\text { Percentage of } \\
\text { samples with } \\
\text { concentrations } \\
\text { less than but } \\
\text { within } 1 \text { order } \\
\text { of magnitude of } \\
\text { benchmark }\end{array}$ & $\begin{array}{l}\text { Percentage of } \\
\text { samples with } \\
\text { concentrations } \\
\text { greater than } \\
\text { benchmark }\end{array}$ \\
\hline Benzene & 1,036 & $0.2 \mu \mathrm{g} / \mathrm{L}$ & .1 & MCL & $5 \mu \mathrm{g} / \mathrm{L}$ & .1 & .0 \\
\hline Deethylatrazine & 1,123 & $0.1 \mu \mathrm{g} / \mathrm{L}$ & 3.4 & $\mathrm{MCL}^{2}$ & $3 \mu \mathrm{g} / \mathrm{L}^{2}$ & ${ }^{2} 1.3$ & ${ }^{2} .0$ \\
\hline Manganese & 1,132 & $1 \mu \mathrm{g} / \mathrm{L}$ & 56.6 & HA & $300 \mu \mathrm{g} / \mathrm{L}$ & 19.0 & 5.0 \\
\hline Nitrate plus nitrite, as $\mathrm{N}$ & 1,136 & $0.05 \mathrm{mg} / \mathrm{L}$ & 73.8 & MCL & $10 \mathrm{mg} / \mathrm{L}$ as $\mathrm{N}$ & 41.6 & 4.3 \\
\hline Strontium & 446 & none & 100.0 & $\mathrm{HA}$ & $4,000 \mu \mathrm{g} / \mathrm{L}$ & 21.3 & 2.2 \\
\hline Trichloroethene (TCE) & 1,041 & $0.2 \mu \mathrm{g} / \mathrm{L}$ & .8 & MCL & $5 \mu \mathrm{g} / \mathrm{L}$ & .4 & .1 \\
\hline Uranium & 901 & $1 \mu \mathrm{g} / \mathrm{L}$ & 38.8 & MCL & $30 \mu \mathrm{g} / \mathrm{L}$ & 22.6 & 1.3 \\
\hline
\end{tabular}

${ }^{1}$ From U.S. Environmental Protection Agency (2006).

${ }^{2} \mathrm{No}$ benchmark is available for deethylatrazine; for purposes in this report, concentrations of deethylatrazine are compared to the human-health benchmark for atrazine of $3 \mu \mathrm{g} / \mathrm{L}$.

${ }^{3}$ Proposed MCL/alternate proposed MCL. 
were counted more than once where major aquifer studies crossed State lines. Detection frequencies are dependent on analytical methods; a low reporting level results in increased detection frequencies. Detection frequencies calculated for this summary (table 5) were censored to a common assessment level because reporting levels for some of the constituents changed through time. The common assessment level also is given in table 5. The highest reporting level through time was used for the common assessment level; strontium did not have a common assessment level because all concentrations were detections.

Radon, arsenic, manganese, nitrate, strontium, and uranium had concentrations that exceeded their human-health benchmarks most frequently (fig. 5). In contrast, organic compounds (pesticides and VOCs) had the lowest percentages of samples with concentrations greater than human-health benchmarks. Consequently, radon, trace elements, and nitrate likely present the greatest potential human-health concern to people using domestic-water supplies in primarily rural parts of the United States. This analysis assumes that current USEPA human-health benchmarks are the most relevant and accurate measure of human-health concern; however, other important considerations may exist for contaminants that were not considered in this analysis. For example, some contaminants that currently do not have human-health benchmarks may cause endocrine disruption (Sumpter and Johnson, 2005). This analysis also does not consider mixtures of contaminants that also may be a human-health concern; the effect of mixtures on human health currently is not well understood.

For each NAWQA major-aquifer study with at least 10 samples, the percentages of samples with concentrations greater than USEPA human-health benchmarks were calculated and are presented in Appendix 5. Radon had the largest number of major-aquifer studies with the largest percentage of samples that had concentrations greater than the USEPA human-health benchmarks. Radon was followed by arsenic, manganese, and nitrate in relative importance of concentrations that were greater than human-health benchmarks. These four contaminants were important for many major-aquifer studies. Some major-aquifer studies had other contaminants of potential human-health concern, such as uranium where more than 15 percent of the samples in one major-aquifer study (sanjsus1) were larger than the USEPA human-health benchmark.

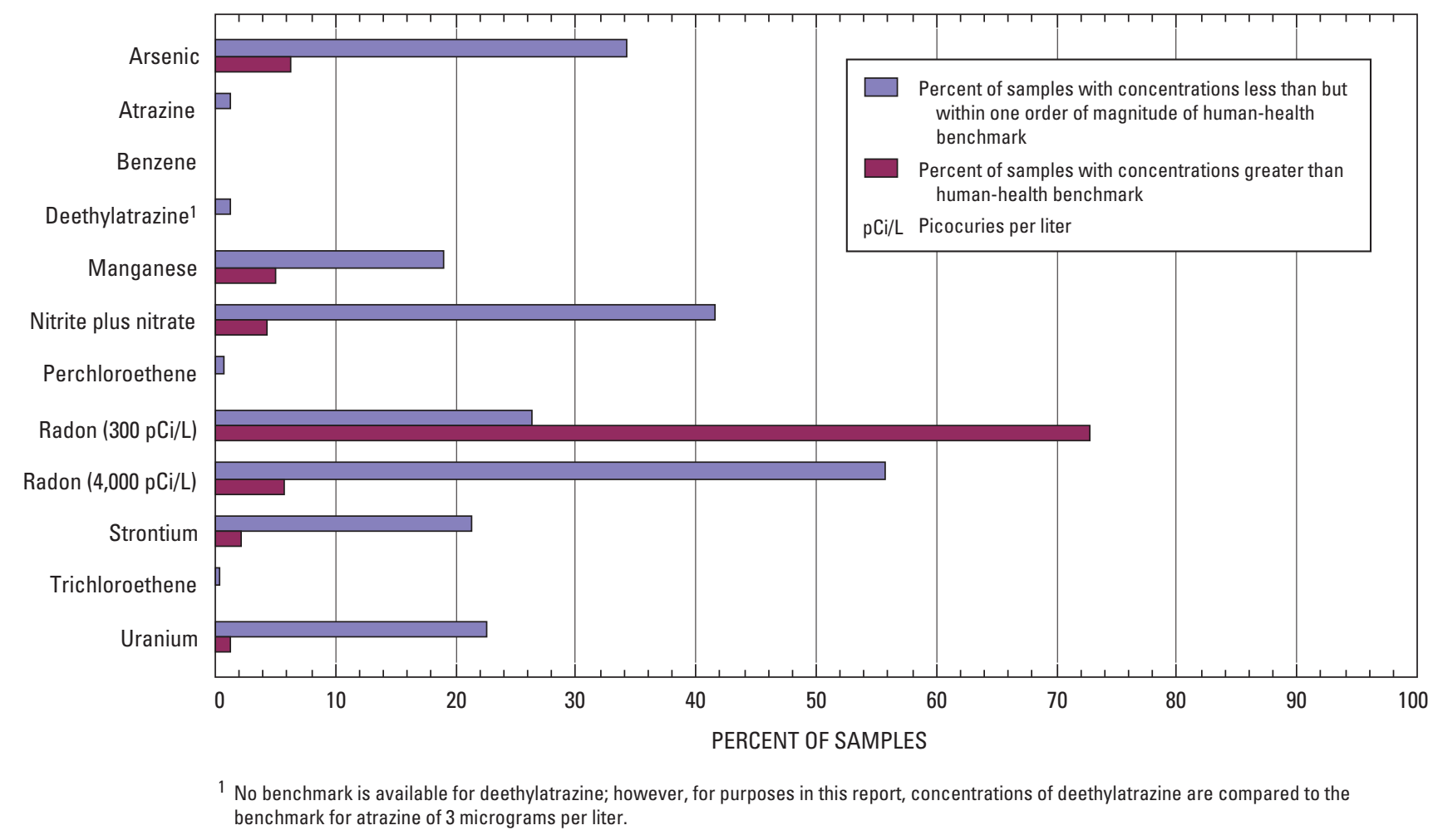

Figure 5. Statistical summary of contaminant concentrations relative to human-health benchmarks in domestic-water supply samples collected by the National Water-Quality Assessment Program in major-aquifer studies associated with 16 grantee States (figure 1). 


\section{Examples of Individual State Data}

A consistent set of water-quality and water-use data for individual States were compiled in Excel spreadsheets for the 16 grantee States. The water-quality spreadsheets are presented in Appendixes 6-8 and the water-use spreadsheets are presented in Appendix 9. The spreadsheets include the files listed in table 6. In addition to basic State-level spreadsheets, a consistent set of summary data tables, graphs, and maps was developed for each State to depict the occurrence and concentrations of the 11 selected contaminants. Maps of key environmental factors such as population density, domesticwater use, and land use and land cover also were developed so comparisons can be made with the occurrence and concentrations of contaminants in ground water. Statistical summaries of the concentrations of the selected contaminants also are provided by major-aquifer study so that the overall water quality of these aquifers can be assessed.

\section{Example Data for New Jersey}

Example tables, graphs, and maps for New Jersey are described in this section of the report to illustrate the usefulness of the New Jersey data. A full set of figures for New Jersey is available in the State summary for New Jersey, which is presented in the following section. Similar tables, graphs, and maps for the other 15 grantee States also are presented in the following section. For each product, descriptions are provided of the data sources, their strengths and limitations, and how the information in each product can be used to meet EPHT project goals and objectives. The products show the environmental setting (population density, population using a domestic water source, and land use/land cover), location of sampled wells, locations of major-aquifer studies and principal aquifers, contaminant concentrations for major-aquifer studies, and the geographic distribution of contaminants using both NAWQA and USGS State data.

Population density (fig. 6) is an important indicator because it can be associated with the certain types of anthropogenic contamination if use and release to the environment increases with population; for example, some solvents and gasoline. For these contaminants, population density can be used in statistical models to help interpolate and extrapolate ground-water-quality data. Population density by census block group is shown for New Jersey using the 2000 Census of Population and Housing (fig. 6). This data set contains demographic data from GeoLytics, East Brunswick, N.J.

Table 6. List of spreadsheets created for each grantee State.

[NAWQA, National Water-Quality Assessment; NWIS, National Water Information System]

\begin{tabular}{|c|c|c|c|}
\hline Appendix/spreadsheet name & File description & $\begin{array}{c}\text { Multiple } \\
\text { worksheets? }\end{array}$ & Worksheets included \\
\hline $\begin{array}{l}\text { Appendix 6/stateinitial.nawqa.data.xls } \\
\text { (for example, NJ.nawqa.data.xls) }\end{array}$ & $\begin{array}{l}\text { Contains well and water-quality } \\
\text { data for all sites sampled by } \\
\text { NAWQA (most recent sample } \\
\text { only) }\end{array}$ & Yes & $\begin{array}{l}\text { (1) Readme1. } \\
\text { (2) Summary statistics. } \\
\text { (3) Data.crosstab (water-quality } \\
\text { data by sample). } \\
\text { (4) Readme } 2 \text {. } \\
\text { (5) Data.unformatted (water- } \\
\text { quality data by contaminant). }\end{array}$ \\
\hline $\begin{array}{l}\text { Appendix } 7 / \text { stateinitial.conc.analysis.by.aquifer.xls } \\
\text { (for example, NJ.nawqa.conc.analysis.by.aquifer.xls) }\end{array}$ & $\begin{array}{l}\text { Contains NAWQA water-quality } \\
\text { data statistics sorted by major- } \\
\text { aquifer study (most recent } \\
\text { sample only) }\end{array}$ & Yes & $\begin{array}{l}\text { (1) Readme1. } \\
\text { (2) Benchmarks. } \\
\text { (3) Aquifer descriptions. } \\
\text { (4) Readme2. } \\
\text { (5) Summary statistics. }\end{array}$ \\
\hline $\begin{array}{l}\text { Appendix 9/stateinitial.wateruse.xls } \\
\text { (for example, NJ.wateruse.xls) }\end{array}$ & $\begin{array}{l}\text { Contains county-level water-use } \\
\text { data for entire State }\end{array}$ & Yes & $\begin{array}{l}\text { (1) Readme. } \\
\text { (2) WU county code. } \\
\text { (3) Water-use data } 2000 \text { (by } \\
\text { county). }\end{array}$ \\
\hline
\end{tabular}




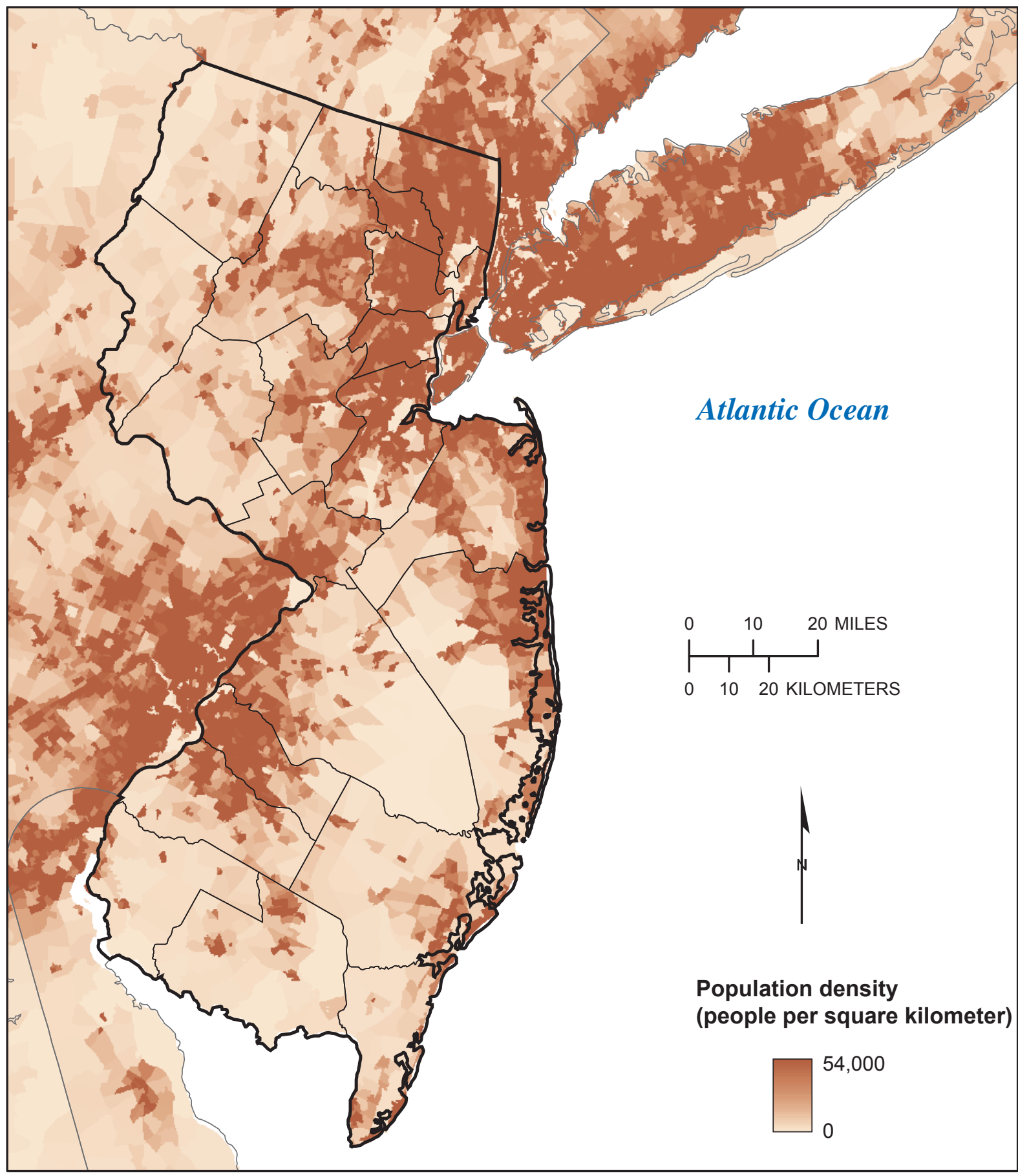

Base information from U.S. Geological Survey digital data, 1:2,000,000 Albers Equal-Area projection

Standard Parallels $29^{\circ} 30^{\prime}$ and 45 $30^{\prime}$, central meridian $-96^{\circ}$

Figure 6. Population density for New Jersey and nearby States. (Data from Hitt, 2003.) 


\section{Summary of Selected U.S. Geological Survey Data on Domestic Well Water Quality}

Figure 7 is an example map showing the estimated number of people using domestic-water supplies by census block group in New Jersey. The data used are from the 1990 population census questionnaire about source of water for the household (U.S. Bureau of Census, 1992). The population using domestic ground water was calculated first by using the number of wells reported in a block group divided by the number of housing units to get the percentage of housing units with wells. This number was then multiplied by the total population in the block group to get the number of people that are using domestic sources of ground water. This map shows that the heavily populated metropolitan centers shown in figure 6 have fewer people using domestic-water supplies. Areas surrounding these centers, however, can have many people using domestic-water supplies. The USGS also has compiled and published national water-use estimates, at the State level, every 5 years since 1950 . This series of water-use reports serves as one of the few sources of information about regional or national trends in water withdrawals. These wateruse data do not estimate consumption from domestic-water supplies nor do they document the presence or absence of a home water purification system; nevertheless, these data can provide some information about potential human exposure. Data files for the most recent compilation (2000) by county for the United States are available at http://water.usgs.gov/watuse/ data/2000/index.html. More information about USGS wateruse data is provided in Appendix 1.

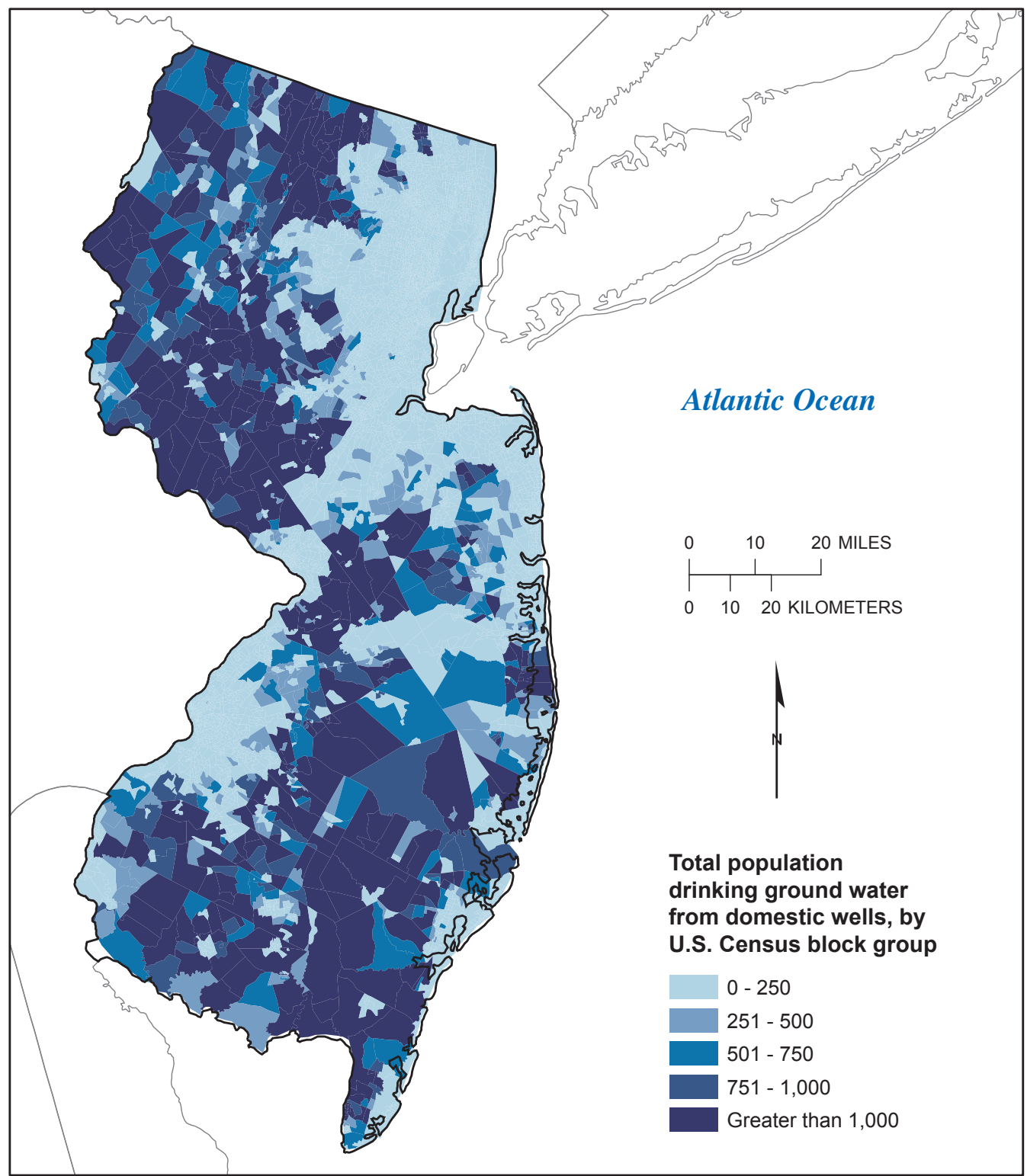

Base information from U.S. Geological Survey digital data, 1:2,000,000 Albers Equal-Area projection

Standard Parallels $29^{\circ} 30^{\prime}$ and $45^{\circ} 30^{\prime}$, central meridian $-96^{\circ}$

Figure 7. Population using domestic-water supply (from ground water) for New Jersey. (Data from 1990 U.S. Census block group, Kerie Hitt, U.S. Geological Survey, written commun., 1997.) 
Figure 8 is an example map showing land use/land cover for New Jersey. Land use and land cover can be associated with certain types of contaminants; for example, some pesticides can be associated with agricultural land use. Forest and barren land, in contrast, can have some of the cleanest ground water. Land use/land cover at a resolution of $1 \mathrm{~km}$ was developed by NAWQA National Synthesis teams using ancillary information for selected land-use/land-cover classes that are better represented in the GIRAS data to enhance the 1992 NLCD (U.S. Geological Survey, 1992). The NLCD also was enhanced using 1990 and 2000 population density by block group to indicate recent (2000) urban development. The NLCD has a resolution of $30 \mathrm{~m}$ and can be too large to work with for regional areas; therefore, a 1-km resolution data set was developed. Within each 1-km grid cell, the land-cover class from the 30-m resolution NLCD representing the highest percentage within the $1-\mathrm{km}$ grid cell was assigned as the value for each cell.

NAWQA conducted seven major-aquifer studies in five principal aquifers (Early Mesozoic basin aquifers, New York/ New England crystalline-rock aquifers, Northern Atlantic Coastal Plain aquifer system, Valley and Ridge aquifers,

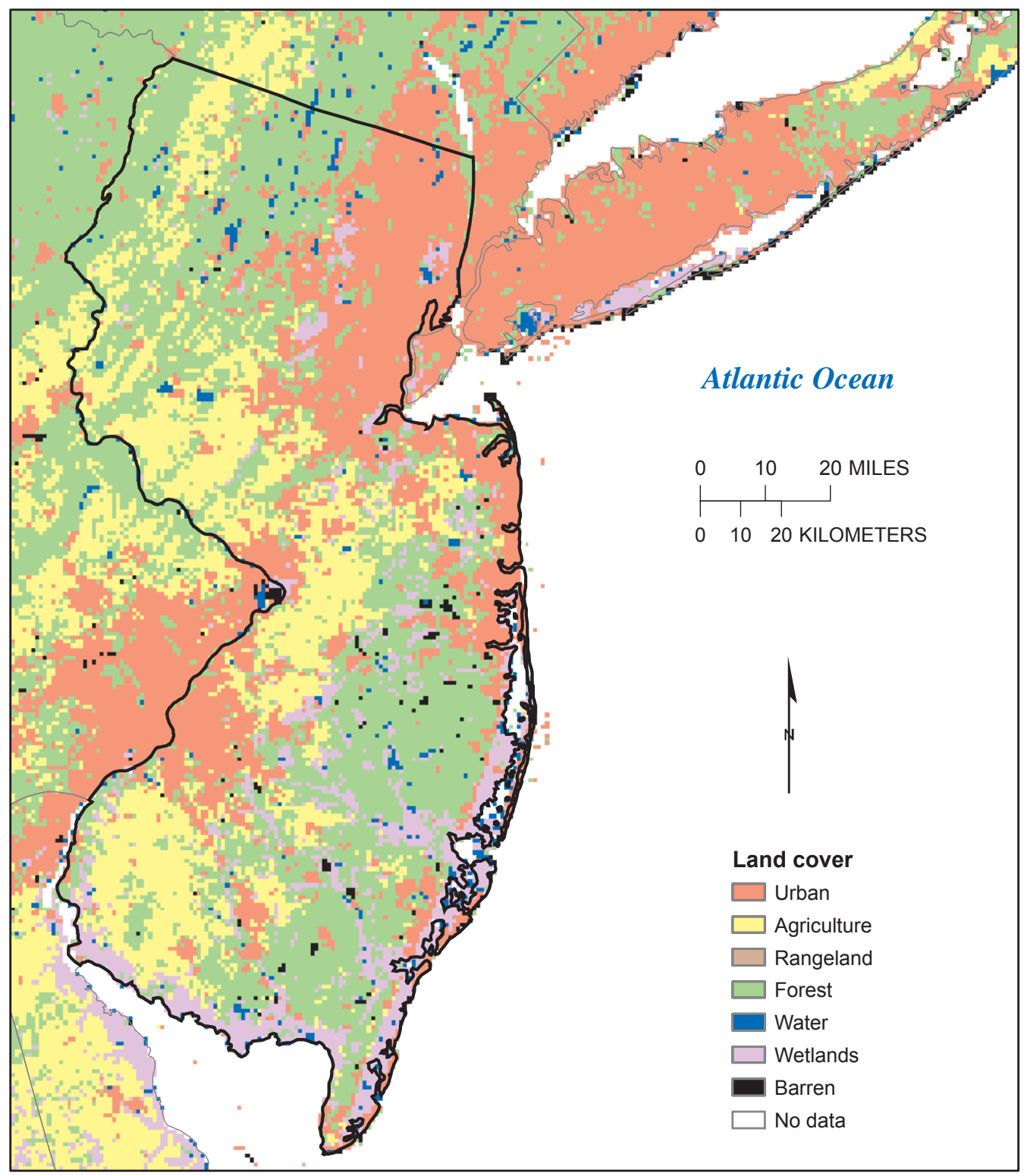

Base information from U.S. Geological Survey digital data, 1:2,000,000

Albers Equal-Area projection

Standard Parallels $29^{\circ} 30^{\prime}$ and $45^{\circ} 30^{\prime}$, central meridian $-96^{\circ}$

Figure 8. Land use/land cover for New Jersey and nearby States. (Data from Naomi Nakagaki, U.S. Geological Survey, written commun., 2005.) 
and glacial aquifers) that are entirely or partially within New Jersey and that are sources of water to domestic-water supplies (fig. 9). Major-aquifer studies were conducted in a single principal aquifer, but the studies also were conducted in areas where the hydrogeologic characteristics were similar. One major-aquifer study, for example, could investigate the water quality in the unconfined part of a principal aquifer and a second major-aquifer study could investigate the confined part of the same principal aquifer. Thus, some principal aquifers have more than one major-aquifer study; for example, two major-aquifer studies were conducted in both the Early Mesozoic basin aquifers and Northern Atlantic Coastal Plain aquifer system for New Jersey. The areal extents of some
NAWQA major-aquifers studies go beyond the State boundary (fig. 9). All data associated with a major-aquifer study are used in contaminant summaries even if the well was located outside the State boundary. About 30 samples generally were collected from existing wells for the NAWQA major-aquifer studies. Subdividing water-quality data from a single majoraquifer study into smaller homogeneous areas generally is not possible unless additional data or information are available. For example, if the detection of a particular pesticide in ground water is associated with a certain type of crop, then land-use activity could be used to identify ground water that is more likely to have this particular pesticide.

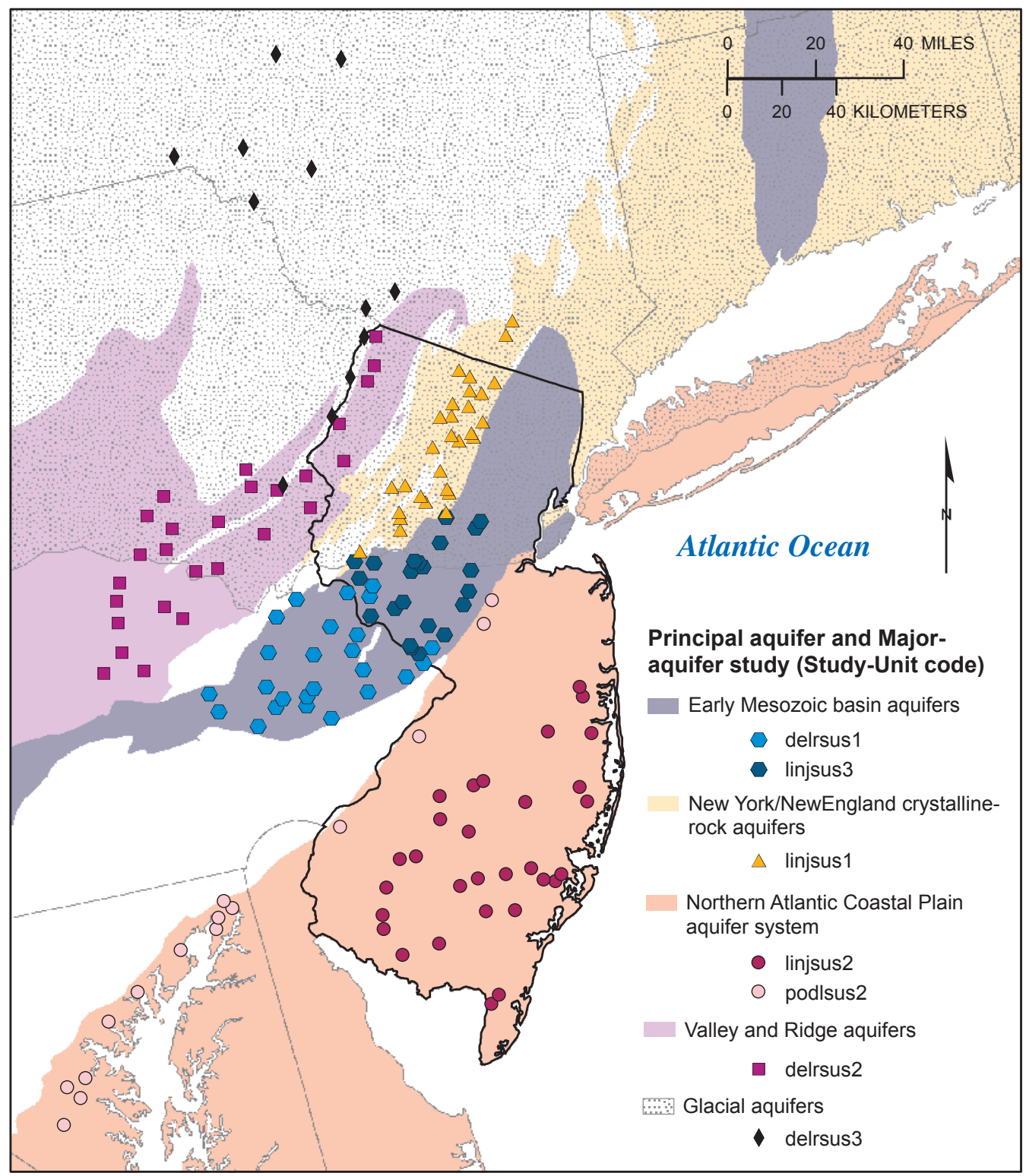

Base information from U.S. Geological Survey digital data, 1:2,000,000 Albers Equal-Area projection

Standard Parallels $29^{\circ} 30^{\prime}$ and $45^{\circ} 30^{\prime}$, central meridian $-96^{\circ}$

Principal aquifer data from U.S. Geological Survey, 2003

Figure 9. Location of domestic wells sampled by the National Water-Quality Assessment (NAWOA) Program for major-aquifer studies with principal aquifers that included New Jersey. 
A statistical summary of chemical concentrations for nitrate is provided in figure 10 for each major-aquifer study that included New Jersey and for which at least 10 samples were collected. Each State summary has a figure similar to this for all 11 constituents. Plots provide median concentrations, range of concentrations for the major-aquifer study (+ signs on the figure), range of concentrations for the entire principal aquifer including samples collected outside the grantee State (shaded area), and the detection frequency based on a common assessment level. The plots also show comparisons of the concentrations to human-health benchmarks. For nitrate in New Jersey, figure 10 shows that glacial aquifers had the smallest median concentration of nitrate and that the Northern Atlantic Coastal Plain and Early Mesozoic basin aquifers had the largest median concentrations of nitrate. This figure also shows that concentrations of nitrate can vary among major-aquifer studies even if they are located within the same principal aquifer. These differences in water quality can be the result of differences in land use/land cover or perhaps geologic differences in the aquifer. The population and land use maps provided may help elucidate some of the reasons for the differences.

Figure 11 is an example map for New Jersey showing nitrate concentrations in domestic-water supply samples from NAWQA major-aquifer studies with principal aquifers and from USGS State data. The concentrations of nitrate in ground-water samples are grouped into three categories relative to the MCL set by the USEPA: (1) less than an order of magnitude of the MCL, (2) less than but within one order of magnitude of the MCL, and (3) greater than the MCL. Spatial trends in nitrate concentrations are apparent within some principal aquifers; for example, nitrate concentrations are greater than or within an order of magnitude of the humanhealth benchmark in the Northern Atlantic Coastal Plain aquifer system in southwestern New Jersey. The spatial trends are more readily apparent in the USGS State data, which are more geographically extensive. Clustering of samples in areas where contaminant concentrations are a concern is not unusual in USGS State data from NWIS because investigative projects can develop as a result of known waterquality problems. These nitrate concentrations greater than or within an order of magnitude of a human-health benchmark appear coincident with agricultural land use (fig. 8). Smaller nitrate concentrations in the eastern coastal plain appear to be associated with less developed land (fig. 8). Water-use data shows that many people could be using domestic-water supplies in both areas (fig. 7).

In summary, NAWQA data can be used to make statistical comparisons among aquifers and provide some information on the geographic distribution of concentrations. NAWQA data can be used to make comparisons among aquifers because of the nationally consistent design, sampling protocols, and analytical methods. USGS State data in NWIS can be helpful to identify the geographic distribution of contaminants. Ancillary information on land use/land cover and population density can be used to help explain the concentrations and distributions of contaminants in aquifers. These kinds of ancillary information can be used in statistical models to interpolate and extrapolate water-quality data. USGS wateruse information can be used to help link the contaminant concentration at a particular location with human exposure. 


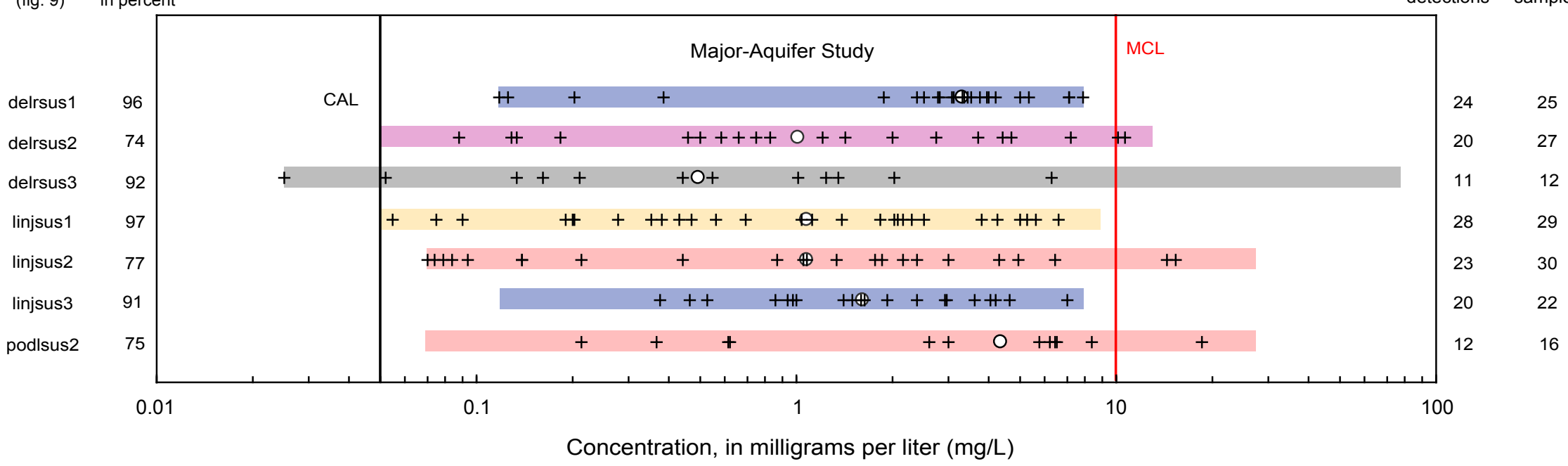

\section{EXPLANATION}

Principal Aquifer - Length of shaded bar represents the range of concentrations detected within the entire aquifer including samples collected outside the grantee State

Early Mezosoic basin aquifers

Valley and Ridge aquifers

Glacial aquifers

New York/New England crystalline-rock aquifers

North Atlantic Coastal Plain aquifer system
+ Detected Concentration - Concentrations are shown for all samples collected in the major-aquifer study without the application of a common assessment level

| Maximum Contaminant Level (MCL), Lifetime Health Advisory (HA), or proposed MCL

Common assessment level (CAL)

O Median of all detections - no application of a common assessment level

96 Detection frequency, in percent, at the common assessment level

24 Number of detections at or above the common assessment level

Figure 10. Statistical summary of nitrate concentrations by major-aquifer study using domestic-well data from National Water-Quality Assessment (NAWQA) studies for New Jersey (includes studies for which at least 10 analyses were available). 


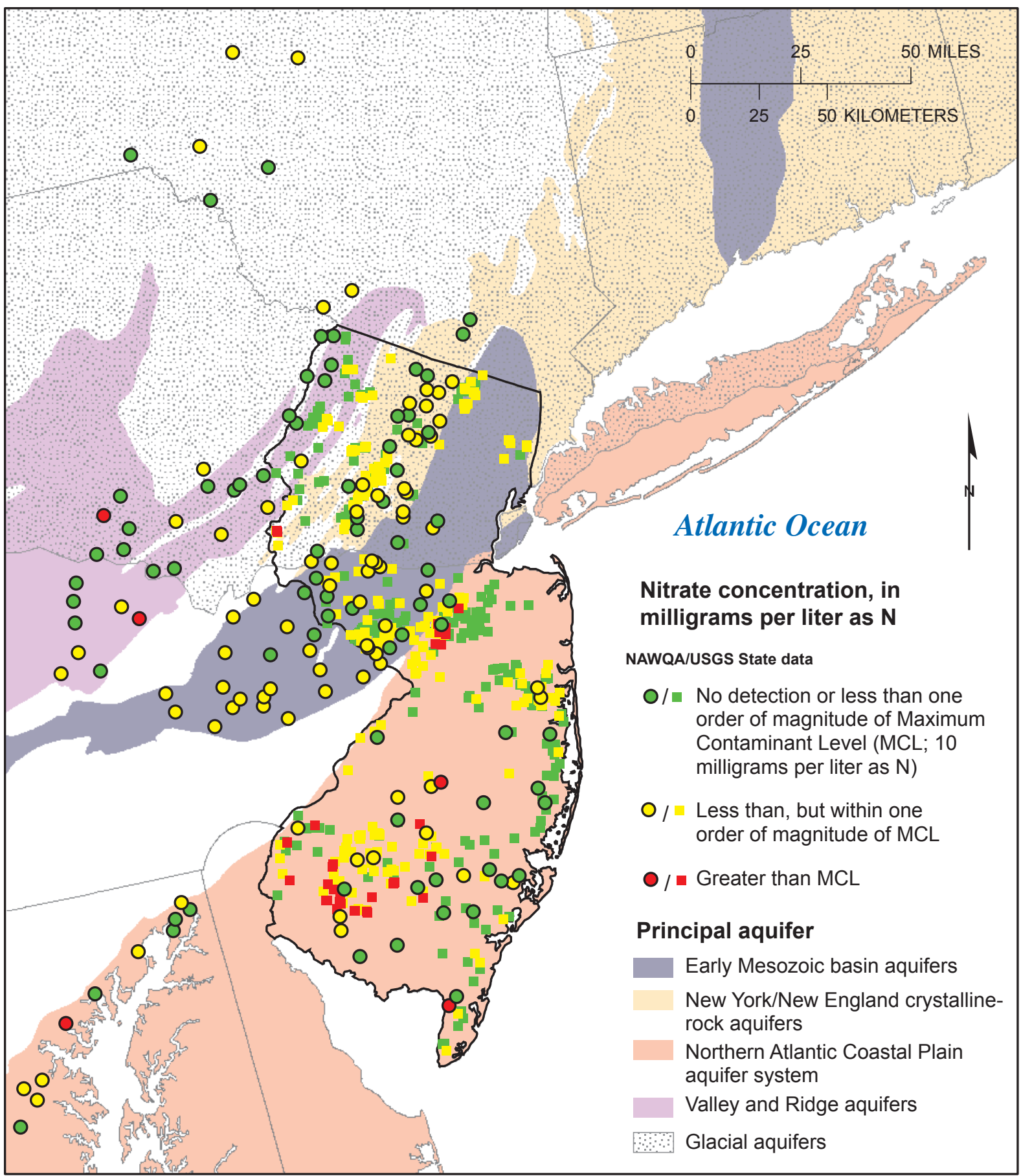

Base information from U.S. Geological Survey digital data, 1:2,000,000 Albers Equal-Area projection

Standard Parallels $29^{\circ} 30^{\prime}$ and $45^{\circ} 30^{\prime}$, central meridian $-96^{\circ}$

Figure 11. Concentration of nitrate in samples from domestic-water supply wells in New Jersey and nearby States (from National Water-Quality Assessment (NAWQA) studies and U.S. Geological Survey (USGS) State data in the National Water Information System (NWIS)). 


\section{State Summaries}

State summaries for the 16 grantee States (California, Connecticut, Florida, Maine, Maryland, Massachusetts, Missouri, New Hampshire, New Jersey, New Mexico, New York, Oregon, Pennsylvania, Utah, Washington, and Wisconsin) are provided in this section of the report. Spreadsheets containing the water-quality and water-use data for the individual States are provided in Appendixes 6-9. The individual State summaries and associated figures can be obtained by clicking on the following links:

California: CAstatesum.pdf
Connecticut: CTstatesum.pdf
Florida: FLstatesum.pdf
Maine: MEstatesum.pdf
Maryland: MDstatesum.pdf
Massachusetts: MAstatesum.pdf
Missouri: MOstatesum.pdf
New Hampshire: NHstatesum.pdf
New Jersey: NJstatesum.pdf
New Mexico: NMstatesum.pdf
New York: NYstatesum.pdf
Oregon: ORstatesum.pdf
Pennsylvania: PAstatesum.pdf
Utah: UTstatesum.pdf
Washington: WAstatesum.pdf
Wisconsin: WIstatesum.pdf

\section{Summary}

About 10 to 30 percent of the population in most States uses domestic (private) water supply. In many States, the total number of people served by domestic supplies can be in the millions. The water quality of domestic supplies is inconsistently regulated and generally not well characterized. The U.S. Geological Survey (USGS) has two water-quality data sets in the National Water Information System (NWIS) database that can be used to help define the water quality of domestic-water supplies: (1) data from the National WaterQuality Assessment (NAWQA) Program, and (2) USGS State data. Data from domestic wells from the NAWQA Program were collected to meet one of the Program's objectives, which was to define the water quality of major aquifers in the United States. These domestic wells were located primarily in rural areas. Water-quality conditions in these major aquifers as defined by the NAWQA data can be compared because of the consistency of the NAWQA sampling design, sampling protocols, and water-quality analyses. The NWIS database is a repository of USGS water data collected for a variety of projects; consequently, project objectives and analytical methods vary. This variability can bias statistical summaries of contaminant occurrence and concentrations; nevertheless, these data can be used to define the geographic distribution of contaminants. Maps created using NAWQA and USGS State data in NWIS can show geographic areas where contaminant concentrations may be of potential human-health concern by showing concentrations relative to human-health water-quality benchmarks.

On the basis of national summaries of detection frequencies and concentrations relative to U.S. Environmental Protection Agency (USEPA) human-health benchmarks for trace elements, pesticides, and volatile organic compounds, 28 water-quality constituents were identified as contaminants of potential human-health concern. From this list,

11 contaminants were selected for summarization of waterquality data in 16 States (grantee States) that were funded by the Environmental Public Health Tracking (EPHT) Program of the Centers for Disease Control and Prevention (CDC). Only data from domestic-water supplies were used in this summary because samples from these wells are most relevant to human exposure for the targeted population. Using NAWQA data, the concentrations of the 11 contaminants were compared to USEPA human-health benchmarks. Using NAWQA and USGS State data in NWIS, the geographic distribution of the contaminants were plotted for the 16 grantee States. Radon, arsenic, manganese, nitrate, strontium, and uranium had the largest percentages of samples with concentrations greater than their human-health benchmarks. In contrast, organic compounds (pesticides and volatile organic compounds) had the lowest percentages of samples with concentrations greater than human-health benchmarks.

Results of data retrievals and spatial analysis were compiled for each of the 16 States and are presented in State summaries for each State. Example summary tables, graphs, and maps based on USGS data for New Jersey are presented to illustrate how USGS water quality and associated ancillary geospatial data can be used by the CDC to address goals and objectives of the EPHT Program.

NAWQA data can be used to make statistical comparisons among aquifers and provide some information on the geographic distribution of concentrations. NAWQA data can be used to make comparisons among aquifers because of the nationally consistent design, sampling protocols, and analytical methods. USGS State data in NWIS can be helpful to identify the geographic distribution of contaminants. Ancillary information on land use/land cover and population density can be used to help explain the concentrations and distributions of contaminants in aquifers. These kinds of ancillary information can be used in statistical models to interpolate and extrapolate water-quality data. USGS wateruse information can be used to help link the contaminant concentration at a particular location with human exposure. 


\section{Selected References}

Agency for Toxic Substances and Disease Registry (ATSDR), 2001, Toxicological profile for asbestos: Atlanta, Ga., U.S. Department of Health and Human Services, Public Health Service.

Ator, S.W., Blomquist, J.D., Brakebill, J.W., Denis, J.M., Ferrari, M.J., Miller, C.V., and Zappia, Humbert, 1998, Water quality in the Potomac River Basin, Maryland, Pennsylvania, Virginia, West Virginia, and the District of Columbia, 1992-96: U.S. Geological Survey Circular 1166, 38 p., accessed March 1, 2007, at http://pubs.water.usgs. gov/circ1166/.

Ayers, M.A., Kennen, J.G., and Stackelberg, P.E., 2000, Water quality in the Long Island-New Jersey coastal drainages New Jersey and New York, 1996-98: U.S. Geological Survey Circular 1201, 40 p., accessed March 1, 2007, at http://pubs.water.usgs.gov/circ1201/.

Colborn T., Vom Saal F.S., Soto, A.M., 1993, Developmental effects of endocrine-disrupting chemicals in wildlife and humans: Environmental Health Perspectives, v. 101, p. 378-384.

Fischer, J.M., Riva-Murray, Karen, Hickman, R.E., Chichester, D.C., Brightbill, R.A., Romanok, K.M., and Bilger, M.D., 2004, Water quality in the Delaware River Basin, Pennsylvania, New Jersey, New York, and Delaware, 1998-2001: U.S. Geological Survey Circular 1227, 48 p., accessed March 1, 2007, at http://pubs.water.usgs.gov/ circ1227/.

Gilliom, R.J., Alley, W.M., and Gurtz, M.E., 1995, Design of the National Water-Quality Assessment ProgramOccurrence and distribution of water-quality conditions: U.S. Geological Survey Circular 1112, accessed May 18, 2007, at http://pubs.usgs.gov/circ/circ1112/.

Hitt, K.J., 2003, 2000 population density by block group for the conterminous United States, accessed June 14, 2007, at http://water.usgs.gov/lookup/getspatial?uspopd00x10g

Hutson, S.S., Barber, N.L., Kenny, J.F., Linsey, K.S., Lumia, D.S., and Maupin, M.A., 2004, Estimated use of water in the United States in 2000: U.S. Geological Survey Circular 1268, 46 p., accessed May 18, 2007, at http://pubs.usgs.gov/circ/2004/circ1268/.

Kettles, M.A., Browning, S.R., Prince, T.S., Horstman, S.W., 1997, Triazine herbicide exposure and breast cancer incidence-An ecologic study of Kentucky counties: Environmental Health Perspectives, v. 105, no. 11, p. $1,222-1,227$.
Morris, R.D., 1995, Drinking water and cancer: Environmental Health Perspectives, v. 103, supplement 8, p. 225-231.

National Center for Environmental Health, 2005, Third national report on human exposure to environmental chemicals: Atlanta, Ga., National Center for Environmental Health Publication No. 05-0570, 467 p.

Neuberger, J.S., 1991, Residential radon exposure and lung cancer-An overview of published studies: Cancer Detection and Prevention, v. 15, p. 435-443.

Price, C.V., Nakagaki, Naomi, Hitt, K.J., and Clawges, R.M., 2003, Mining GIRAS - Improving on a national treasure of land use data in Proceedings of the 23rd ESRI International Users Conference, July 7-11, 2003, Redlands, Calif., accessed September 13, 2007, at http://gis.esri.com/library/ userconf/proc03/p0904.pdf

Price, C.V., Nakagaki, Naomi, Hitt, K.J., and Clawges, R.M., 2006, Enhanced historical land-use and land-cover data sets of the U.S. Geological Survey: U.S. Geological Survey Data Series 240, accessed August 13, 2007, at http://pubs.usgs. gov/ds/2006/240/.

Sumpter, J.P., and Johnson, A.C., 2005, Lessons from endocrine disruption and their application to other issues concerning trace organics in the aquatic environment: Environmental Science and Technology, v. 103, p. 173-187.

Tao, X.G., Zhu, H.G., Yu, S.Z., Zhao, Q.Y., Wang, J.R., Wu, G.D., You, X.F., Li, C., Zhi, W.L., Bao, J.P., Sun, Z.Q., 1991, Pilot study on the relationship between male stomach and liver cancer death and the mutagenicity of drinkingwater in the Huangpu River area: Public Health Review, v. 19, p. 219-227.

Trapp, Henry, Jr., and Horn, M.A., 1997, Ground water atlas of the United States-Delaware, Maryland, New Jersey, North Carolina, Pennsylvania, Virginia, and West Virginia: U.S. Geological Survey Hydrologic Atlas HA 730-L, accessed May 30, 2007, at http://capp.water.usgs.gov/gwa/ ch_l/index.html

U.S. Bureau of the Census, 1992, Census of population and housing, 1990 - Summary tape file 3A on CD-ROM (machine-readable data file): Washington, D.C., The Bureau (producer and distributor).

U.S. Environmental Protection Agency, 2003, Revised atrazine IRED in Decision documents for atrazine: Washington, D.C., Office of Prevention, Pesticides and Toxic Substances, accessed May 18, 2007, at http://www.epa.gov/oppsrrdl/ REDs/atrazine_combined_docs.pdf 
U.S. Environmental Protection Agency, 2005, Public Drinking Water Systems Program: accessed November 2, 2005, at http://www.epa.gov/safewater/pws/index.html

U.S. Environmental Protection Agency, 2006, 2006 Edition of the drinking water standards and health advisories: Washington, D.C., Office of Water, EPA 822-R-06-013, accessed February 20, 2007, at http://www.epa.gov/ waterscience/criteria/drinking/dwstandards.pdf

U.S. Geological Survey, 1992, National Land Cover Dataset 1992 (NLCD 1992), accessed February 20, 2007, at http://landcover.usgs.gov/natllandcover.php

U.S. Geological Survey, 1998, National Water Information System (NWIS): U.S. Geological Survey Fact Sheet FS-027-98, accessed February 20, 2007, at http://pubs.usgs.gov/fs/FS-027-98/.

U.S. Geological Survey, 2003, Principal aquifers of the 48 conterminous United States, Hawaii, Puerto Rico, and the U.S. Virgin Islands, accessed March 1, 2007, at http://www.nationalatlas.gov/mld/aquifrp.html

Van Leeuwen, J.A., Waltner-Toews, D., Abernathy, T., Smit, B., and Shoukri, M., 1999, Association between stomach cancer incidence and drinking water contamination with atrazine and nitrate in Ontario (Canada) agroecosystems, 1987-1991: International Journal of Epidemiology, v. 28, no. 5, p. 836-840.

Vogelmann, J.E., Howard, S.M., Yang, L., Larson, C.R., Wylie, B.K., and Van Driel, N., 2001, Completion of the 1990s National Land Cover Data Set for the conterminous United States from Landsat Thematic Mapper data and ancillary data sources: Photogrammetric Engineering \& Remote Sensing, v. 67, p. 650-662.

Wasserman, G.A., Liu, Xinhua, Parvez, Faruque, Ahsan, Habibul, Levy, Diane, Factor-Lityak, Pam, Kline, Jennie, van Geen, Alexander, Slavkovich, Vesna, Lolacono, N.J., Cheng, Zhongqi, Zheng, Yan, and Graziano, J.H., 2006, Water manganese exposure and children's intellectual function in Araihazar, Bangladesh: Environmental Health Perspectives, v. 114, no. 1, p. 124-129.

Zogorski, J.S., Carter, J.M., Ivahnenko, Tamara, Lapham, W.W., Moran, M.J., Rowe, B.L., Squillace, P.J., and Toccalino, P.L., 2006, The quality of our Nation's waters-Volatile organic compounds in the Nation's ground water and drinking-water supply wells, U.S. Geological Survey Circular 1292, 101 p., accessed March 1, 2007, at http://pubs.usgs.gov/circ/circ1292/. 


\section{Appendixes}

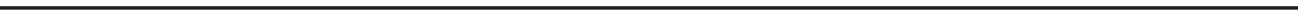




\section{Appendix 1. Description of Selected U.S. Geological Survey Databases.}

The U.S. Geological Survey (USGS) has several water-related databases that store a variety of information. This section provides information about the following USGS databases: (1) National Water-Quality Assessment (NAWQA), (2) water use, (3) National Water Information System (NWIS), (4) National Stream Quality Accounting Network (NASQAN), (5) National Atmospheric Deposition Program/National Trends Network (NADP/NTN), and (6) Health-Based Screening Levels (HBSLs). NAWQA, water-use, and NASQAN data are included in the NWIS database. Selected NAWQA, water-use, and NWIS data are included and summarized in this report. Table 7 defines the fields used in the tables to describe each database included in this section. 
Table 7. Definition of fields used to describe selected U.S. Geological Survey databases.

[EPHTN, Environmental Public Health Tracking Network; QA/QC, quality assurance/quality control; URL, Uniform Resource Locator; USGS, U.S. Geological Survey; WWW, World Wide Web]

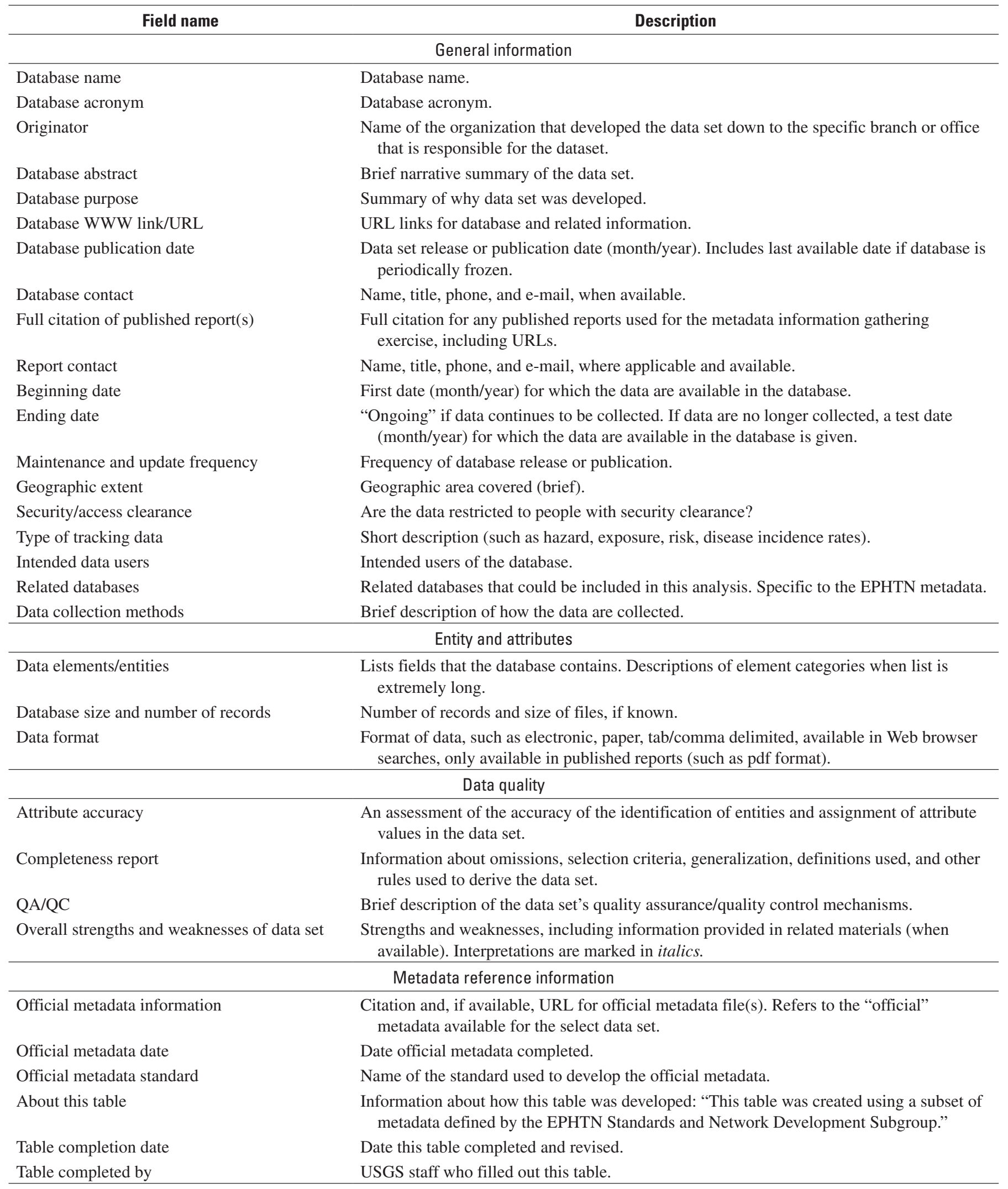




\section{National Water-Quality Assessment Database}

The USGS's NAWQA Program has collected information on the quality of streams, ground water, and aquatic ecosystems since 1991. Information for the NAWQA database is presented in table 8. 
Table 8. Selected information for the National Water-Quality Assessment database.

[Interpretations within the "Overall strengths and weaknesses of data set" are in italics. EPHTN, Environmental Public Health Tracking Network; NAWQA, National Water-Quality Assessment; QA/QC, quality assurance/quality control; URL, Uniform Resource Locator; USGS, U.S. Geological Survey; VOC, volatile organic compound; WWW, World Wide Web]

\begin{tabular}{|c|c|}
\hline Field name & Description for National Water-Quality Assessment database \\
\hline \multicolumn{2}{|r|}{ General information } \\
\hline Originator & U.S. Geological Survey (USGS). \\
\hline
\end{tabular}

Database WWW link/URL

Database publication date

Beginning date

Ending date

Maintenance and update frequency

Geographic extent

Database contact

Security/access clearance

Full citation of published report(s)

Report contact

Type of tracking data

Intended data users http://water.usgs.gov/nawqa/data

Information not provided.

1999 (http://infotrek.er.usgs.gov/docs/nawqa_www/DATA_WAREHOUSE_ABSTRACT.HTM).

Ongoing.

Weekly.

National scale with emphasis in selected river basins and major aquifers. See map at http://water.usgs.gov/pubs/fs/fs-071-01/images/cycle2mod.gif

U.S. Department of the Interior, U.S. Geological Survey

Contact for NAWQA: nawqa_whq@usgs.gov

Maintainer: James Ulrich-julrich@usgs.gov

Open source and has an online query system.

There are hundreds of published reports. A partial list of summary reports is located at http://water.usgs.gov/nawqa/nawqa_sumr.html

Email: infoservices@usgs.gov Telephone: 303-202-4700.

Hazard.

Local, State, regional, national decision makers, and researchers. Because each Study-Unit assessment adheres to a national design and nationally consistent sampling and analytical methods, water-quality conditions in a specific locality or watershed can be compared to those in other geographic regions and at different periods of time. Collectively, the assessments advance an understanding of the quality of our Nation's waters and whether water quality is getting better or worse over time. Information at different scales helps to bridge local, State, regional, and national efforts to manage the Nation's water resources. (http://pubs.usgs.gov/fs/fs-071-01/pdf/fs07101.pdf). 
Table 8. Selected information for the National Water-Quality Assessment database.—Continued

[Interpretations within the "Overall strengths and weaknesses of data set" are in italics. EPHTN, Environmental Public Health Tracking Network; NAWQA, National Water-Quality Assessment; QA/QC, quality assurance/quality control; URL, Uniform Resource Locator; USGS, U.S. Geological Survey; VOC, volatile organic compound; WWW, World Wide Web]

\begin{tabular}{ll}
\hline \multicolumn{1}{c}{ Field name } & \multicolumn{1}{c}{ Description for National Water-Quality Assessment database } \\
\hline Related databases & General information-Continued \\
Data collection methods & See the following list: http://water.usgs.gov/nawqa/links.html \\
Method, sampling, and analytical protocols are found at \\
http://water.usgs.gov/nawqa/protocols/methodprotocols.html \\
Biological sampling, habitat, and laboratory protocols documents are found at \\
http://water.usgs.gov/nawqa/protocols/bioprotocols.html \\
Ground-water quality is assessed by three primary study components: \\
1. Study-Unit Surveys assess the water quality of the major aquifer systems of the Study Unit by sampling \\
primarily existing wells. \\
2. Land-Use Studies use observation wells and selected existing wells to assess the quality of recently \\
recharged shallow ground water associated with regionally extensive combinations of land use and \\
hydrogeologic conditions. \\
3. Flow-path studies use transects and groups of clustered, multilevel observation wells to examine \\
specific relations among land-use practices, ground-water flow, contaminant occurrence and transport, \\
and surface- and ground-water interaction. (http://pubs.usgs.gov/circ/circll12/images/tab10.gif)
\end{tabular}

Entity and attributes

Data elements/ entities

Volatile organic compounds (VOCs) are listed at http://sd.water.usgs.gov/nawqa/vocns/2020.qw.std.fy02.rdb

Dibromomethane; bromodichloromethane; tetrachloromethane, 1,2-dichloroethane; tribromomethane; dibromochloromethane; trichloromethane; methylbenzene; benzene; 2-propenal; 2-propenenitrile; chlorobenzene; chloroethane; ethylbenzene; 1,1,1,2,2,2-hexachloroethane; bromomethane; chloromethane; dichloromethane; tetrachloroethene; trichlorofluoromethane; 1,1-dichloroethane; 1,1-dichloroethene; 1,1,1-trichloroethane; 1,1,2-trichloroethane; 1,1,2,2-tetrachloroethane; 1,2-dichlorobenzene; 1,2-dichloropropane; trans-1,2-dichloroethene; 1,2,4-trichlorobenzene; 1,3-dichlorobenzene; 1,4-dichlorobenzene; dichlorodifluoromethane; naphthalene; trans-1,3dichloropropene; cis-1,3-dichloropropene; chloroethene; trichloroethene; 1,1,2,3,4,4-hexachloro1,3-butadiene; methyl-2-propenoate; 1,2,3,4-tetramethylbenzene; 1,2,3,5-tetramethylbenzene; bromoethene; ethyl tert-butyl ether; tert-amyl methyl ether; trans-1,4-dichloro-2-butene; ethyl methacrylate; carbon disulfide; vinyl acetate; cis-1,2-dichloroethene; 2-hexanone; ethenylbenzene; 1,2-dimethylbenzene; 1,1-dichloropropene; 2,2-dichloropropane; 1,3-dichloropropane; 2-ethyltoluene; 1,2,3-trimethylbenzene; 1,2,4-trimethylbenzene; (1-methylethyl)benzene; n-propylbenzene; 1,3,5trimethylbenzene; 1-chloro-2-methylbenzene; 1-chloro-4-methylbenzene; bromochloromethane; n-butylbenzene; (1-methylpropyl)benzene; (1,1-dimethylethyl)benzene; 1-isopropyl-4-methylbenzene; iodomethane; 1,2,3-trichloropropane; 1,1,1,2-tetrachloroethane; 1,2,3-trichlorobenzene; 1,2dibromoethane; 1,1,2-trichloro-1,2,2-trifluoroethane; methyl tert-butyl ether; 3-chloro-1-propene; 4-methyl-2-pentanone; dimethylbenzenes; acetone; bromobenzene; diethyl ether; diisopropyl ether; methyl acrylonitrile; 2-butanone; methyl methacrylate; tetrahydrofuran; 1,2-dibromo-3-chloropropane; 1,3- and 1,4-dimethylbenzene.

Pesticides are listed at http://ca.water.usgs.gov/pnsp/anstrat/ 2,4,5-T (triclopyr); 2,4,5-TP (silvex); 2,4-D; 2,4-DB; 2,6-diethylaniline; 3-hydroxycarbofuran; acetochlor; acifluorfen; alachlor; aldicarb; aldicarb sulfone; aldicarb sulfoxide; atrazine; atrazine, deethyl; azinphos-methyl; benfluralin; bentazon; bromacil; bromoxynil; butylate; carbaryl; carbofuran; chloramben; chlorothalonil; chlorpyrifos; clopyralid; cyanazine; dacthal (DCPA); dacthal, mono acid; DDE, p,p'; diazinon; dicamba; dichlobenil; dichlorprop; dieldrin; dinoseb; disulfoton; diuron; DNOC; EPTC; ethalfluralin; ethoprop; fenuron; fluometuron; fonofos; $\mathrm{HCH}$, alpha; $\mathrm{HCH}$, gamma (lindane); linuron; malathion; MCPA; MCPB; methiocarb; methomyl; methyl parathion; metolachlor; metribuzin; molinate; napropamide; neburon; norflurazon; oryzalin; oxamyl; parathion; pebulate; pendimethalin; permethrin, cis; phorate; picloram; prometon; pronamide; propachlor; propanil; propargite; propham; propoxur; simazine; tebuthiuron; terbacil; terbufos; thiobencarb; triallate; triclopyr; trifluralin.

Trace elements are listed at http://water.usgs.gov/nawqa/trace/analytes.html

- Ground water: aluminum; antimony; arsenic; barium; beryllium; boron; cadmium; chromium; cobalt; copper; iron; lead; lithium; manganese; mercury; molybdenum; nickel; radium-224; radium-226; 
Table 8. Selected information for the National Water-Quality Assessment database.-Continued

[Interpretations within the "Overall strengths and weaknesses of data set" are in italics. EPHTN, Environmental Public Health Tracking Network; NAWQA, National Water-Quality Assessment; QA/QC, quality assurance/quality control; URL, Uniform Resource Locator; USGS, U.S. Geological Survey; VOC, volatile organic compound; WWW, World Wide Web]

\begin{tabular}{|c|c|}
\hline Field name & Description for National Water-Quality Assessment database \\
\hline \multicolumn{2}{|r|}{ Entity and attributes-Continued } \\
\hline $\begin{array}{l}\text { Data elements/ entities-con- } \\
\text { tinued }\end{array}$ & $\begin{array}{l}\text { radium-228; radon-222; selenium; silver; strontium; thallium; uranium; vanadium; zinc; gross alpha- } \\
\text { radioactivity; gross beta-radioactivity. } \\
\text { - Streambed sediments: aluminum; antimony; arsenic; barium; beryllium; cadmium; chromium; cobalt; } \\
\text { copper; iron; lead; manganese; mercury; molybdenum; nickel; selenium; silver; strontium; titanium; } \\
\text { uranium; vanadium; zinc. } \\
\text { - Fish and clam tissue: aluminum; antimony; arsenic; barium; beryllium; boron; cadmium; chromium; } \\
\text { cobalt; copper; iron; lead; manganese; mercury; molybdenum; nickel; selenium; silver; strontium; } \\
\text { uranium; vanadium; zinc. } \\
\text { The NAWQA database also includes other types of water-quality data, such as major ions and physical } \\
\text { properties. }\end{array}$ \\
\hline $\begin{array}{l}\text { Database size and number of } \\
\text { records }\end{array}$ & 11 million in 2004 (http://water.usgs.gov/nawqa/sumr/04nr/dataWarehouse.pdf). \\
\hline Completeness report & Information not provided. \\
\hline QA/QC & $\begin{array}{l}\text { Several guidance documents listed at } h t t p: / / w a t e r . u s g s . g o v / \text { nawqa/protocols/methodprotocols.html have } \\
\text { been published to promote consistent data collection, sampling, analysis, and reporting. }\end{array}$ \\
\hline $\begin{array}{l}\text { Overall strengths and } \\
\text { weaknesses of data set }\end{array}$ & $\begin{array}{l}\text { NAWQA has a balanced representation between ground-water studies, surface-water studies, and } \\
\text { ecological studies with data collected throughout the Nation (see map). The data are varied and } \\
\text { relevant to determining overall quality of surface water and ground water, as well as ecological health. } \\
\text { Data are available online. NAWQA aquifer studies (also called Study-Unit Surveys or Major Aquifer } \\
\text { Studies) are probably most relevant to human health for rural areas of the nation where untreated } \\
\text { ground water is used as a source of domestic water. The purpose of these studies is to define the quality } \\
\text { of the ground-water resource. Each aquifer study generally contained } 30 \text { samples collected from } \\
\text { existing wells. These studies have three unique characteristics. First, samples were collected before any } \\
\text { treatment to define the quality of water in the aquifer. Second, sampled wells were spatially distributed } \\
\text { and randomly selected among existing wells within the targeted aquifer. Third, most of the samples were } \\
\text { collected from domestic wells (one well that provides water to one home) in rural areas of the nation. } \\
\text { Almost all water samples have reported concentrations for VOCs, pesticides, and trace elements. } \\
\text { Statistical summaries of NAWQA aquifer studies provide a description of the overall water quality of the } \\
\text { study area. Comparisons can be made between aquifer studies based on these summaries. Subdividing } \\
\text { an aquifer study into smaller homogeneous areas is not possible unless additional data or information } \\
\text { are available. For example, if the detection of a particular pesticide in ground water is associated with } \\
\text { a certain type of crop, then land-use activity could be used to identify ground water more likely to have } \\
\text { this particular pesticide. } \\
\text { NAWQA data are not directly measuring exposure or human health, but NAWQA data provide a } \\
\text { foundation or framework for comparing and defining ground-water quality across the Nation. }\end{array}$ \\
\hline
\end{tabular}

\section{Metadata reference information}

Official metadata information

Official metadata date

Official metadata standard

About this table

Table completion date

Table completed by
Information not provided.

Information not provided.

Information not provided.

This table was created using a subset of metadata defined by the EPHTN Standards and Network Development Subgroup.

February 2006.

Paul Squillace. 


\section{Water-Use Data by County}

The USGS has compiled and published national-scale and State-scale water-use estimates every 5 years since 1950. Information for the USGS water-use database is presented in table 9. 
Table 9. Selected information for the water-use database.

[Interpretations within the "Overall strengths and weaknesses of data set" are in italics. EPHTN, Environmental Public Health Tracking Network; NAWQA, National Water-Quality Assessment Program; QA/QC, quality assurance/quality control; SDWIS, Safe Drinking Water Information System; URL, Uniform Resource Locator; USDA, U.S. Department of Agriculture; USDOE-EIA, U.S. Department of Energy-Energy Information Administration; USEPA, U.S. Environmental Protection Agency; USGS, U.S. Geological Survey; WWW, World Wide Web]

\begin{tabular}{ll}
\hline Field name & Description for water-use database \\
\hline & General information
\end{tabular}

Originator

Database abstract

Database purpose

Database WWW link/URL

Database publication date

Beginning date

Ending date

Maintenance and update frequency

Geographic extent

Database contact

Security/access clearance

Full citation of published report(s)

Report contact

Type of tracking data

Intended data users

Intended data uses

Related databases

Data collection methods
U.S. Geological Survey (USGS).

The USGS has compiled and published national water-use estimates, at the State level, every 5 years since 1950. The series of water-use reports serves as one of the few sources of information about regional or national trends in water withdrawals (Circular 1268). Data files for the most recent compilation present water-use estimates for 2000 by county for the United States, the District of Columbia, Puerto Rico, and the U.S. Virgin Islands, which support the State-level water-use estimates (http://water.usgs.gov/watuse/data/2000/index.html and Circular 1268). Circular 1268 provides information on eight categories of water use-public supply, domestic, irrigation, livestock, aquaculture, industrial, mining, and thermoelectric power. County data files for 1985 and 1990 and for 1995 also are available for download. For each of the county-level 5-year compilations since 1985, data collection, types and characteristics differ. No water-use estimates were compiled by water-resources cataloging unit or by water-resources region for 2000. Although not collected at the county level, the 2000 USGS Water-use compilation effort included assigning state-wide ground-water withdrawals for public-supply, irrigation and industrial uses to principal aquifers (Circular 1279: http://pubs.usgs.gov/circ/2005/1279/).

Presents consistent and current water-use estimates by source, category of use and State (Circular 1268). Companion report of water-use estimates for three major uses (public supply, irrigation, and industry) by principal aquifer (Circular 1279: http://pubs.usgs.gov/circ/2005/1279/).

http://water.usgs.gov/watuse/data/2000/index.html

Published in 2004 for 2000 water-use data.

1985.

Ongoing.

State totals completed every 5 years starting in 1950. County data reported from 1985-2005.

National, 50 States plus Puerto Rico and the Virgin Islands.

wu-web@usgs.gov for national database. Water use point of contact for each state are listed at http://water.usgs.gov/watuse/wupersonnel.html

No restrictions.

Released March 2004, revised April 2004, May 2004, February 2005. Report: http://water.usgs.gov/pubs/circ/2004/circ1268/.

http://pubs.usgs.gov/circ/2004/circ1268/listed:

U.S. Geological Survey

Information Services

Box 25286

Denver, CO 80225

phone: 1-888-ASK-USGS, e-mail: infoservices@usgs.gov

None (tracking water sources and water uses-indirectly related to exposure).

Local, State, regional, national decision makers, and researchers.

Appropriate for use by community/State/local and basin planning committees for resource management, investigations and research purposes.

None.

National http://water.usgs.gov/pubs/chapter11/. 
Table 9. Selected information for the water-use database.-Continued

[Interpretations within the "Overall strengths and weaknesses of data set" are in italics. EPHTN, Environmental Public Health Tracking Network; NAWQA, National Water-Quality Assessment Program; QA/QC, quality assurance/quality control; SDWIS, Safe Drinking Water Information System; URL, Uniform Resource Locator; USDA, U.S. Department of Agriculture; USDOE-EIA, U.S. Department of Energy-Energy Information Administration; USEPA, U.S. Environmental Protection Agency; USGS, U.S. Geological Survey; WWW, World Wide Web]

\begin{tabular}{|c|c|}
\hline Field name & Description for water-use database \\
\hline \multicolumn{2}{|r|}{ Entity and attributes } \\
\hline Data elements/ entities & $\begin{array}{l}\text { Data collection (http://water.usgs.gov/watuse/data/2000/index.html): } \\
\text { - All States collected data for public supply, domestic, irrigation, industrial, and thermoelectric power } \\
\text { water use. These categories represented } 97 \text { percent of water use during } 1995 \text {. } \\
\text { - Although all States collected data for domestic water use and for public supply population } \\
\text { served, some States did not report this data at the county level. Those States will have totals in } \\
\text { Circular 1268, but will show blanks for domestic self-supplied population, domestic fresh ground- } \\
\text { water withdrawals, domestic fresh surface-water withdrawals, domestic total fresh withdrawals, } \\
\text { and/or public-supply total population served in the county-level data files. If county-level estimates } \\
\text { for domestic water use are not available, the total water-use data elements also will be blank in the } \\
\text { data files. If totals were calculated without the domestic water-use estimates, they would not agree } \\
\text { with the totals for those States in Circular } 1268 \text {. } \\
\text { - Selected States collected data for } 2000 \text { in the categories of livestock, aquaculture, and mining. These } \\
\text { States include those with the largest uses of water in these categories in } 1995 \text {. The data files show } \\
\text { blanks for States that did not compile data for these categories. } \\
\text { - No consumptive-use data were collected for any of the categories for } 2000 \text {. } \\
\text { - No public-supply delivery data were reported for } 2000 \text {. The data may have been collected but they } \\
\text { didn't require that data to be reported to the national team for inclusion in the report. } \\
\text { Data dictionary: http://water.usgs.gov/watuse/data/2000/datadict.html } \\
\text { County codes for each State are listed at http://www.itl.nist.gov/fipspubs/co-codes/states.htm }\end{array}$ \\
\hline $\begin{array}{l}\text { Database size and number of } \\
\text { records }\end{array}$ & Information not provided. \\
\hline Data format & Excel spreadsheet. \\
\hline
\end{tabular}

Data quality

Attribute accuracy

Completeness report

See guidelines report (http://pubs.usgs.gov/tm/2005/tm4A4/) for information.

QA/QC

Guidelines for 2000 water-use data compilation are found at http://pubs.usgs.gov/tm/2005/tm4A4/.

The following national data were available to each State: U.S. Environmental Protection Agency (USEPA) Safe Drinking Water Information System (SDWIS); U.S. Census Bureau, population; U.S. Department of Agriculture (USDA) Farm and Ranch Irrigation Survey; USDA Census of Agriculture; USDA, national agricultural statistics; and U.S. Department of Energy-Energy Information Administration (USDOE-EIA), steam-electric plant statistics. Each USGS study chief was responsible for determining the most reliable sources of information available for estimating water use for their State.

Each USGS study chief compiled and analyzed information from various sources, made estimates of missing data, and prepared documentation that identified the sources of water-use information and methods used to determine water use for their State. Many States published reports on water use as part of the National Water Use Information Program. A list of these publications is available on the Internet. 
Table 9. Selected information for the water-use database.-Continued

[Interpretations within the "Overall strengths and weaknesses of data set" are in italics. EPHTN, Environmental Public Health Tracking Network; NAWQA, National Water-Quality Assessment Program; QA/QC, quality assurance/quality control; SDWIS, Safe Drinking Water Information System; URL, Uniform Resource Locator; USDA, U.S. Department of Agriculture; USDOE-EIA, U.S. Department of Energy-Energy Information Administration; USEPA, U.S. Environmental Protection Agency; USGS, U.S. Geological Survey; WWW, World Wide Web]

\begin{tabular}{|c|c|}
\hline Field name & Description for water-use database \\
\hline \multicolumn{2}{|r|}{ Data quality-Continued } \\
\hline \multirow[t]{3}{*}{$\begin{array}{l}\text { Overall strengths and weaknesses } \\
\text { of data set }\end{array}$} & $\begin{array}{l}\text { Water use by county provides a basic measurement of how water is used by public, domestic, and a } \\
\text { variety of other consumers in the nation. For each county, the number of people using domestic } \\
\text { self-supplied sources of water and the number of people using public water supplies is listed } \\
\text { (http://water.usgs.gov/watuse/data/2000/datadict.html). These data provide a basic understanding of } \\
\text { the source of potable water. For public water supplies, ground-water and surface-water withdrawals } \\
\text { are estimated separately. For domestic self-supplied sources, water usually is from a well } \\
\text { http://water.usgs.gov/pubs/circ/2004/circ1268/). }\end{array}$ \\
\hline & $\begin{array}{l}\text { These water-use data could be more helpful if water use was estimated in smaller areas (census blocks) } \\
\text { and if the source of surface and ground water was defined. However, if only one aquifer is available } \\
\text { for potable water in a particular county, then water-quality data from NAWQA aquifer studies can } \\
\text { be linked with these water use data to estimate human exposure to those using domestic-water } \\
\text { supplies (assuming potable water is untreated and consumed in the home). In areas with more than } \\
\text { one aquifer, more detailed water-use information is needed to estimate human exposure. These data } \\
\text { may be available from the States, or they could be estimated by comparing the number of deep and } \\
\text { shallow domestic wells if aquifers are stratified. Currently (2007), the NAWQA water-use group is } \\
\text { working to identify the principal aquifers that are sources of water to public supply wells, and have } \\
\text { been approached to identify the aquifers that are sources to domestic wells. }\end{array}$ \\
\hline & $\begin{array}{l}\text { URL http://water.usgs.gov/watuse/wudo.html provides an estimated use of domestic water in the United } \\
\text { States in 1990. Domestic water use includes water for normal household purposes, such as drinking, } \\
\text { food preparation, bathing, washing clothes and dishes, flushing toilets, and watering lawns and } \\
\text { gardens. In 1990, } 42.8 \text { million people, or } 17 \text { percent of the Nation's total population, were served } \\
\text { by their own water-supply systems, compared with } 42.5 \text { million people in 1985. Similar water use } \\
\text { summaries are available for every year that data were compiled. }\end{array}$ \\
\hline
\end{tabular}

Metadata reference information

Official metadata information

Official metadata date

Official metadata standard

About this table

Table completion date

Table completed by
Information not provided.

Information not provided.

Information not provided.

This table was created using a subset of metadata defined by the EPHTN Standards and Network Development Subgroup.

February 2006.

Paul Squillace. 


\section{National Water Information System Database}

The National Water Information System (NWIS) database contains many types of data including site information, timeseries (flow, stage, precipitation, chemical), peak-flow, ground-water, water-quality, and water-use data. Information for the NWIS database is presented in table 10. 
Table 10. Selected information for the National Water Information System database.

[Interpretations within the "Overall strengths and weaknesses of data set" are in italics. ASCII, American Standard Code for Information Interchange; EPHTN, Environmental Public Health Tracking Network; NAWQA, National Water-Quality Assessment; NWIS, National Water Information System; QA/QC, quality assurance/quality control; URL, Uniform Resource Locator; USGS, U.S. Geological Survey; WWW, World Wide Web]

\begin{tabular}{|c|c|}
\hline Field name & Description for National Water Information System database \\
\hline \multicolumn{2}{|r|}{ General information } \\
\hline Originator & U.S. Geological Survey (USGS). \\
\hline
\end{tabular}

Database purpose

As part of the U.S. Geological Survey's (USGS) program of disseminating water data to the public, the USGS maintains a distributed network of computers and fileservers for the storage and retrieval of water data collected through its activities at approximately 1.5 million sites around the country. This system is called the National Water Information System (NWIS). Many types of data are stored in this NWIS network, including site information, time-series (flow, stage, precipitation, chemical), peak flow, ground water, and water quality (http://waterdata.usgs.gov/nwis/help?nwisweb_overview).

The goal of NWISWeb is to provide both internal and external users of USGS water information with an easy to use, geographically seamless interface to the large volume of USGS water data maintained on 48 separate NWIS databases nationwide. NWISWeb provides several output options: real-time streamflow, water-level and water-quality graphs, data tables, and site maps; tabular output in html and ASCII tab-delimited files; lists of selected sites as summaries with reselection for details (http://waterdata.usgs. gov/nwis/help?nwisweb_overview).

Database WWW link/URL

Database publication date

Beginning date

Ending date

Maintenance and update frequency

Geographic extent

Database contact

Security/access clearance

Full citation of published report(s)

\section{http://waterdata.usgs.gov/nwis/qw}

Information not provided.

Information not provided, but data go back more than 100 years (http://pubs.usgs.gov/fs/fs-128-02/).

Ongoing.

Data is updated from the NWIS sites on a regularly scheduled basis; real-time data is transmitted to NWISWeb several times a day (http://waterdata.usgs.gov/nwis/help?nwisweb_overview).

All real-time data are provisional and subject to revision.

Data are collected by USGS personnel in all 50 States, plus Puerto Rico and Guam (http://pubs.usgs.gov/fs/FS-027-98/).

General assistance in the operation and application of NWIS is available from the NWIS office in Reston, Va., (Email: nwis_help@mailnwis.er.usgs.gov).

Water data are available at local Web sites that can be accessed at http://water.usgs.gov/index.html

Contact information for the USGS State Representatives is available at http://water.usgs.gov/staterep.html

The contact's name, address, email address, telephone and facsimile numbers, and open hours are included for each office (http://pubs.usgs.gov/fs/FS-027-98/).

None.

NWISWeb: New Site for the Nation's Water Data (http://pubs.usgs.gov/fs/fs-128-02/).

National Water Information System (NWIS) (http://pubs.usgs.gov/fs/FS-027-98/). 
Table 10. Selected information for the National Water Information System database.-Continued

[Interpretations within the "Overall strengths and weaknesses of data set" are in italics. ASCII, American Standard Code for Information Interchange; EPHTN, Environmental Public Health Tracking Network; NAWQA, National Water-Quality Assessment; NWIS, National Water Information System; QA/QC, quality assurance/quality control; URL, Uniform Resource Locator; USGS, U.S. Geological Survey; WWW, World Wide Web]

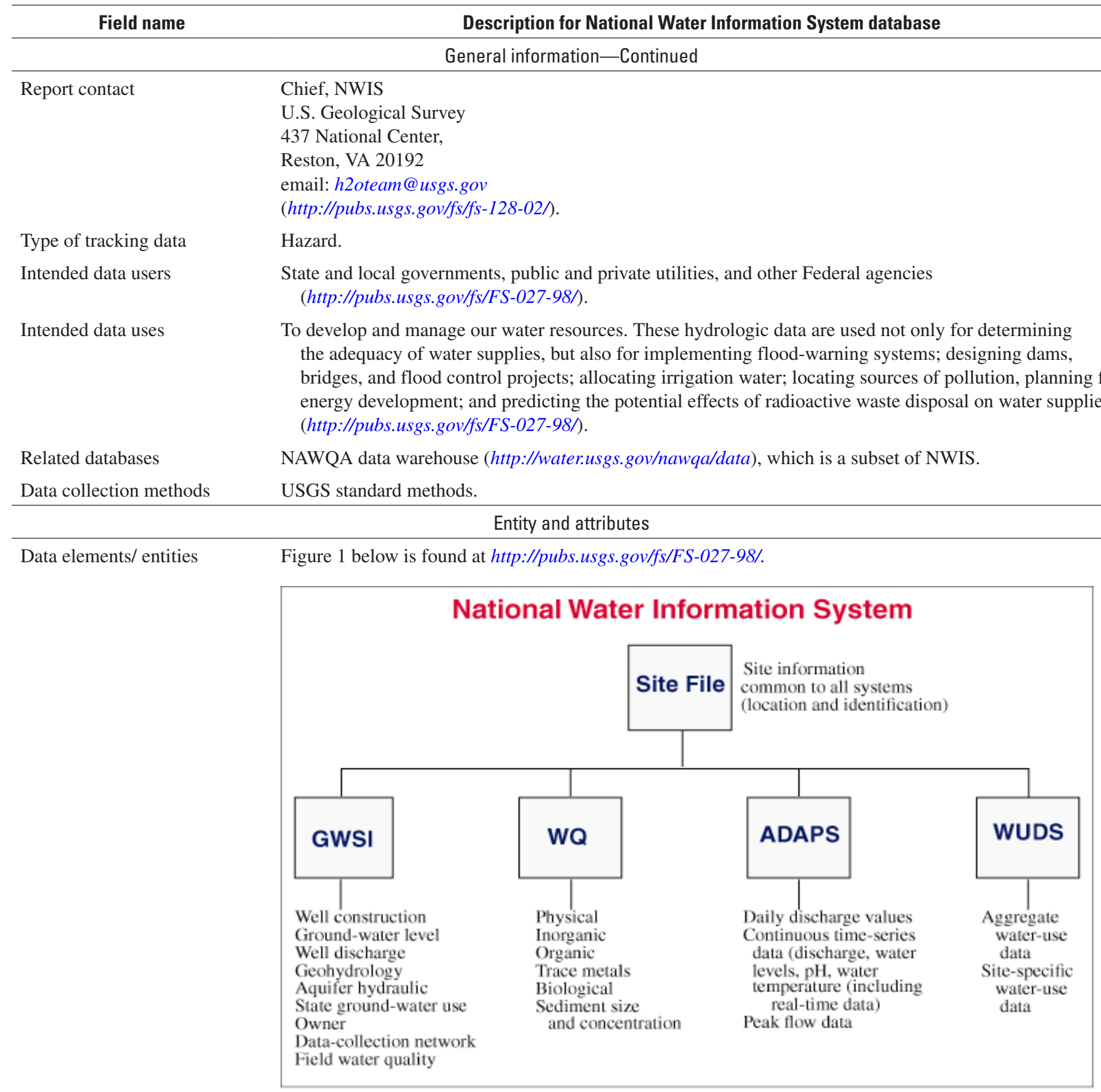

Figure 1. NWIS structure and types of stored hydrologic data 
Table 10. Selected information for the National Water Information System database.-Continued

[Interpretations within the "Overall strengths and weaknesses of data set" are in italics. ASCII, American Standard Code for Information Interchange; EPHTN, Environmental Public Health Tracking Network; NAWQA, National Water-Quality Assessment; NWIS, National Water Information System; QA/QC, quality assurance/quality control; URL, Uniform Resource Locator; USGS, U.S. Geological Survey; WWW, World Wide Web]

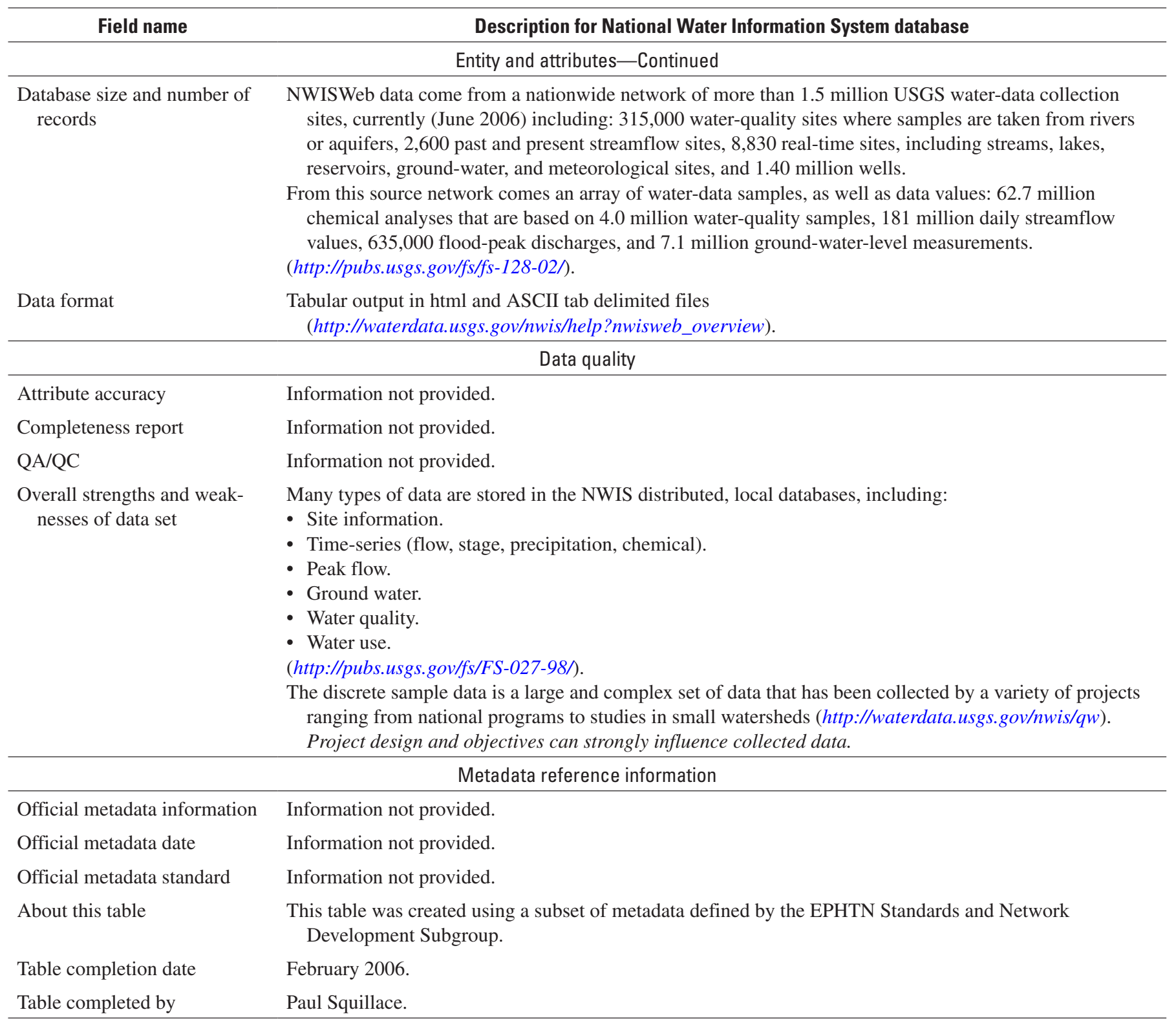




\section{National Stream Quality Accounting Network Database}

The National Stream Quality Accounting Network (NASQAN) program provides ongoing characterization of the concentrations and flux of sediment and chemicals in the Nation's largest rivers. Information for the NASQAN database is presented in table 11 . 
Table 11. Selected information for the National Stream Quality Accounting Network database:

[Interpretations within the "Overall strengths and weaknesses of data set" are in italics. ASCII, American Standard Code for Information Interchange; EPHTN, Environmental Public Health Tracking Network; HBN, Hydrologic Benchmark Network; NASQAN, National Stream Quality Accounting Network; NWQL, National Water Quality Laboratory; QA/QC, quality assurance/quality control; RDB, relational database; URL, Uniform Resource Locator; USGS, U.S. Geological Survey; WWW, World Wide Web]

\begin{tabular}{cc}
\hline Field name & Description for National Stream Quality Accounting Network database \\
\hline General information
\end{tabular}

Originator

Database abstract

Database purpose

Database WWW link/URL

Database publication date

Beginning date

Ending date

Maintenance and update frequency

Geographic extent

\section{U.S. Geological Survey (USGS).}

NASQAN program design has changed since its inception in 1974 (http://water.usgs.gov/nasqan/ progdocs/index.html).

1974-1995

The major impetus for establishing the NASQAN program in 1974 was to develop a baseline waterchemistry data set that was long-term and systematically collected throughout the Nation. The original network consisted of more than 500 stations sampled at monthly intervals. Measured constituents included nutrients, major ions, and suspended sediment. Over time, the program was constrained by budget cuts and corresponding reductions were made in sampling, both in terms of station numbers and sampling frequency. By 1994, the program was limited to quarterly sampling at roughly 275 stations.

Data were collected at uniform time intervals, without concern for the hydrologic patterns of high or low flow, and therefore provide a fairly representative description of conditions on any given day. These data are appropriate for trend detection and can be used for load estimation ONLY if a sufficient number of years are considered together so as to cover a broad range of discharges.

Additional water-quality monitoring was conducted by the Hydrologic Benchmark Network (HBN), which was established in 1963. This program focused on relatively small and minimally disturbed watersheds. It provides data that are used to evaluate trends in water quality over time and serves as a control for distinguishing natural variability in small streams from effects induced by human activity. $\underline{1996-2000}$

After a major redesign in 1995, the NASQAN program focused on monitoring the water quality of the nation's largest rivers-the Mississippi (including the Missouri and Ohio), the Columbia, the Colorado, and the Rio Grande. During this phase of the program, NASQAN operated a network of approximately 41 stations where the concentration of an expanded range of chemicals, including pesticides and trace elements, was measured in tandem with stream discharge. Stations were chosen at major nodes within the river basin network to provide characterization of large subbasins of these rivers.

The sampling strategy was changed to focus on characterizing the variations in chemical and sediment concentrations that occur during a year, particularly the variation that occurs between low and high flows and during different seasons. In this way, NASQAN data can be used to evaluate mass fluxes or loads of constituents to ultimately determine regional source areas for these materials. $\underline{2001-2005}$

In 2001, the NASQAN program entered a 5-year special study phase that included substantially decreasing sampling in two basins, the Colorado and Columbia, and redirecting resources to an intensive sampling program in the Yukon Basin. Sampling continued unchanged in the Mississippi and Rio Grande Basins, but only one or two index stations were sampled in the Columbia and the Colorado Basins. In the Yukon Basin, fixed-station monitoring to determine constituent fluxes was supplemented with a series of synoptic cruises. These synoptic cruises were designed to provide baseline data on organic-carbon dynamics in response to the melting of permafrost in the Arctic.

The NASQAN program provides ongoing characterization of the concentrations and flux of sediment and chemicals in the Nation's largest rivers (http://water.usgs.gov/nasqan/).

http://water.usgs.gov/nasqan/data/index.html

Information not provided.

1996.

Ongoing.

Ongoing.

Current monitoring stations located in Mississippi, Columbia, Colorado and Rio Grande Basins. See map at http://water.usgs.gov/nasqan/images/stations.2001.gif 
Table 11. Selected information for the National Stream Quality Accounting Network database.-Continued

[Interpretations within the "Overall strengths and weaknesses of data set" are in italics. ASCII, American Standard Code for Information Interchange; EPHTN, Environmental Public Health Tracking Network; HBN, Hydrologic Benchmark Network; NASQAN, National Stream Quality Accounting Network; NWQL, National Water Quality Laboratory; QA/QC, quality assurance/quality control; RDB, relational database; URL, Uniform Resource Locator; USGS, U.S. Geological Survey; WWW, World Wide Web]

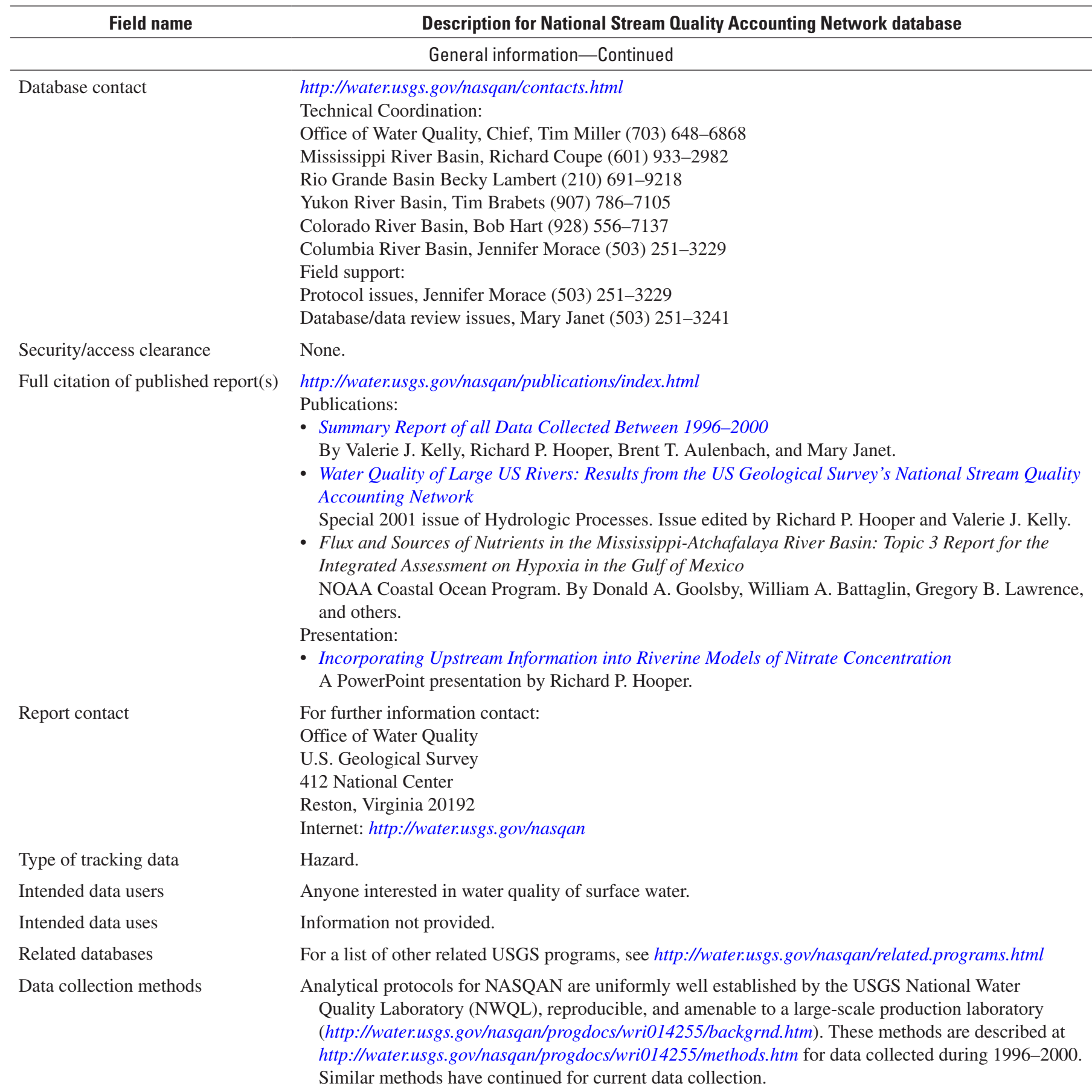


Table 11. Selected information for the National Stream Quality Accounting Network database.—Continued

[Interpretations within the "Overall strengths and weaknesses of data set" are in italics. ASCII, American Standard Code for Information Interchange; EPHTN, Environmental Public Health Tracking Network; HBN, Hydrologic Benchmark Network; NASQAN, National Stream Quality Accounting Network; NWQL, National Water Quality Laboratory; QA/QC, quality assurance/quality control; RDB, relational database; URL, Uniform Resource Locator; USGS, U.S. Geological Survey; WWW, World Wide Web]

\begin{tabular}{|c|c|}
\hline Field name & Description for National Stream Quality Accounting Network database \\
\hline \multicolumn{2}{|r|}{ Entity and attributes } \\
\hline Data elements/ entities & $\begin{array}{l}\text { A broad suite of constituents was measured at all stations, including suspended sediment, major ions, } \\
\text { nutrients, dissolved trace elements, suspended sediment chemistry, selected dissolved pesticides, and } \\
\text { field parameters. }\end{array}$ \\
\hline $\begin{array}{l}\text { Database size and number of } \\
\text { records }\end{array}$ & Information not provided. \\
\hline
\end{tabular}
Data quality

Attribute accuracy

Completeness report

QA/QC

Overall strengths and weaknesses of data set
Information not provided.

Information not provided.

QC data for the 1996-2000 data are provided at http://water.usgs.gov/nasqan/progdocs/wri014255/ results/qc.htm

NASQAN reports discharge and water quality for surface water across the nation. The objectives of NASQAN have changed since its inception making data incomplete for many locations. Large rivers are used as source water for many public water systems. Typical water treatment for public water systems may not remove some contaminants. For these contaminants, NASQAN data may provide an indication of human exposure and how concentrations can vary with season and discharge.

Metadata reference information

Official metadata information

Metadata are available for the 1996-2000 NASQAN sites linked from http://water.usgs.gov/nasqan/ data/index.html at http://water.usgs.gov/GIS/metadata/usgswrd/XML/nasqan2k.xml. An example of the metadata provided from NASQAN is available for a Yukon River Study at http://agdc.usgs. gov/data/usgs/water/metadata/yuk_wat.html

Official metadata date

Various.

FGDC Content Standards for Digital Geospatial Metadata (“CSDGM version 2").

Official metadata standard

This table was created using a subset of metadata defined by the EPHTN Standards and Network Development Subgroup.

Table completion date February 2006.

Table completed by
Paul Squillace. 


\section{National Atmospheric Deposition Program/National Trends Network Database}

The National Atmospheric Deposition Program/National Trends Network (NADP/NTN) provides the only long-term nationwide record of wet deposition in the United States. Information for the NADP/NTN database is presented in table 12. 
Table 12. Selected information for the National Atmospheric Deposition Program/National Trends Network database.

[Interpretations within the "Overall strengths and weaknesses of data set" are in italics. AIRMoN, Atmospheric Integrated Research Monitoring Network; EPHTN, Environmental Public Health Tracking Network; MDN, Mercury Deposition Network; mg/L, milligrams per liter; NADP/NTN, National Atmospheric Deposition Program/National Trends Network; QA/QC, quality assurance/quality control; SVOC, semi-volatile organic compound; URL, Uniform Resource Locator; USGS, U.S. Geological Survey; WWW, World Wide Web]

\begin{tabular}{|c|c|}
\hline Field name & Description for National Atmospheric Deposition Program/National Trends Network database \\
\hline \multicolumn{2}{|r|}{ General information } \\
\hline Originator & $\begin{array}{l}\text { Cooperative research support program involving State Agricultural Experiment Stations, U.S. } \\
\text { Geological Survey (USGS), U.S. Department of Agriculture, other Federal agencies, and numerous } \\
\text { other State, local, and Tribal government agencies and non-governmental organizations (http:// } \\
\text { nadp.sws.uiuc.edu/nadpoverview.asp). For a list, see collaborating agencies page. }\end{array}$ \\
\hline Database abstract & $\begin{array}{l}\text { The National Atmospheric Deposition Program/National Trends Network (NADP/NTN) provides } \\
\text { the only long-term nationwide record of wet deposition in the United States. The NADP/NTN } \\
\text { has grown from } 22 \text { stations at the end of 1978, the first year of operations, to more than } 250 \text { sites } \\
\text { spanning the continental United States, Alaska, Puerto Rico, and the Virgin Islands. Each NADP/ } \\
\text { NTN site collects 1-week precipitation-only samples according to strict clean-handling procedures. } \\
\text { All samples are sent to the NADP Central Analytical Laboratory, which measures free acidity } \\
\text { (hydrogen ion as pH), sulfate, nitrate, ammonium, chloride, and base cations (calcium, magnesium, } \\
\text { potassium and sodium) (http://nadp.sws.uiuc.edu/nadpoverview.asp). } \\
\text { The NADP operates two other networks: } \\
\text { 1. The Mercury Deposition Network (MDN), currently (2007) with more than } 90 \text { sites, joined the } \\
\text { NADP in 1996. The MDN offers the only regional-scale measurements of mercury in North } \\
\text { American precipitation. MDN data are used to quantify the total amount of mercury deposited } \\
\text { by precipitation to lake and stream watersheds, particularly where there are fish or wildlife } \\
\text { consumption advisories due to high levels of this toxic chemical. } \\
\text { 2. The Atmospheric Integrated Research Monitoring Network (AIRMoN), joined the NADP in } 1992 \\
\text { and has eight eastern U.S. sites that collect samples daily. AIRMoN samples are analyzed for the } \\
\text { same constituents as NTN samples. The daily measurements support continued research of airborne } \\
\text { pollutant transport and removal processes, as well as the development of computer simulations of } \\
\text { these processes. }\end{array}$ \\
\hline
\end{tabular}

Database purpose

The purpose of the NADP/NTN is to provide quality-assured data and information in support of research on the exposure of managed and natural ecosystems and cultural resources to acidic compounds, nutrients, and base cations in precipitation. These data support informed decisions on air quality issues related to precipitation chemistry and are used by scientists, policy-makers, and the general public. The network is designed especially for evaluating geographical and temporal long-term trends in chemical deposition.

Database WWW link/URL

Database publication date

Beginning date

Ending date

Maintenance and update frequency

Geographic extent

Database contact http://nadp.sws.uiuc.edu/.

Database updated approximately monthly.

July 1978.

Present.

Online data updated approximately monthly with a 6-month delay (http://nadp.sws.uiuc.edu/ nadpdata/).

Continental United States, Alaska, Puerto Rico, Virgin Islands.

Mailing Address for all Program Office Staff (http://nadp.sws.uiuc.edu/contacts.asp).

NADP Program Office

Illinois State Water Survey

2204 Griffith Drive

Champaign, IL 61820-7495

Program Information, Van C. Bowersox, Coordinator, 217-333-7873

Quality Assurance Information, Chris Lehmann, QA Manager, 217-265-8512

Data/Web Page Information, Bob Larson, Database Manager, 217-333-9008

AIRMoN Program/AIRMoN Data, Van C. Bowersox, Coordinator, 217-333-7873

Technical/Database Information, Bob Larson, Database Manager, 217-333-9008

Mercury Deposition Network, David Gay, NADP Assistant Coordinator for Toxics, 217-244-0462. 
Table 12. Selected information for the National Atmospheric Deposition Program/National Trends Network database.-Continued

[Interpretations within the "Overall strengths and weaknesses of data set" are in italics. AIRMoN, Atmospheric Integrated Research Monitoring Network; EPHTN, Environmental Public Health Tracking Network; MDN, Mercury Deposition Network; mg/L, milligrams per liter; NADP/NTN, National Atmospheric Deposition Program/National Trends Network; QA/QC, quality assurance/quality control; SVOC, semi-volatile organic compound; URL, Uniform Resource Locator; USGS, U.S. Geological Survey; WWW, World Wide Web]

\begin{tabular}{cc}
\hline Field name & Description for National Atmospheric Deposition Program/National Trends Network database \\
\hline General information-Continued \\
\hline
\end{tabular}

Security/access clearance

Full citation of published report(s)

Report contact

Type of tracking data

Intended data users

Intended data uses

Related databases

Data collection methods
None.

See the URL http://nadp.sws.uiuc.edu/lib/ for detailed information.

Requests for Publications, Kathy E. Douglas, 217-333-7873, 217-333-0249 (FAX).

Hazard.

Scientists, policy-makers, educators, and the public.

http://nadp.sws.uiuc.edu/lib/program/SAES422-2004.pdf

To investigate the impacts of atmospheric deposition on the productivity of managed and natural ecosystems; on the chemistry of estuarine, surface and ground waters; and on biodiversity in forests, shrubs, grasslands, deserts, and alpine vegetation. Researchers also use NADP MDN data to examine the role of atmospheric deposition in affecting the mercury content of fish, and better understand the link between environmental and dietary mercury and human health.

There are two additional networks-Mercury Deposition Network $(M D N)$, and Atmospheric Integrated Research Monitoring Network (AIRMoN).

(http://nadp.sws.uiuc.edu/QA/)

The concentrations of dissolved substances in precipitation are generally quite low (less than 1 percent of NADP precipitation samples have total dissolved chemical concentrations greater than $20 \mathrm{mg} / \mathrm{L}$ ). Chemical measurements of precipitation samples require thorough quality assurance (QA) and quality control (QC) procedures to assure that meaningful data are obtained. Biases can result from: sample handling contamination; losses to sample container walls; chemical, physical, and biological changes; and variations in collection and analytical procedures. Stringent QA and QC procedures are essential for obtaining unbiased, precise, and representative atmospheric deposition measurements and for maintaining the integrity of the sample during collection, handling, and analysis. Equally stringent procedures must be applied to data management to assure that the accuracy of the data is maintained.

QA is stressed in all aspects of NADP operations. Sites are required to meet minimum siting standards, use approved instruments, and follow standard procedures. The NADP analytical laboratories operate under well-defined QA programs with well-defined QC criteria. QA continues for processing, coding, and reporting data to the Program Office. QA procedures, however, are not static sets of rules. They are modified to accommodate program changes and in response to the experience accumulated from past practices.

NADP QA programs are aimed toward providing representative data of documented bias, precision, and completeness to assist data users in evaluating the appropriateness of the data for a particular application. Specifically, it is the NADP quality management policy to accomplish the following:

- Develop scientifically based methodologies for data collection and assessment to provide continued quality improvement.

- Provide quality assessments of network operations to assist network management and cooperating agencies in improving network monitoring strategies.

- Provide estimates of completeness, precision, bias, and representativeness for all spatial and temporal data values reported.

- Provide complete and concise records of NADP policies, procedures and quality assessments.

- Permanently associate network quality assurance documentation with reported data. 
Table 12. Selected information for the National Atmospheric Deposition Program/National Trends Network database.-Continued

[Interpretations within the "Overall strengths and weaknesses of data set" are in italics. AIRMoN, Atmospheric Integrated Research Monitoring Network; EPHTN, Environmental Public Health Tracking Network; MDN, Mercury Deposition Network; mg/L, milligrams per liter; NADP/NTN, National Atmospheric Deposition Program/National Trends Network; QA/QC, quality assurance/quality control; SVOC, semi-volatile organic compound; URL, Uniform Resource Locator; USGS, U.S. Geological Survey; WWW, World Wide Web]

\begin{tabular}{|c|c|}
\hline Field name & Description for National Atmospheric Deposition Program/National Trends Network database \\
\hline \multicolumn{2}{|r|}{ Entity and attributes } \\
\hline Data elements/ entities & $\begin{array}{l}\text { Format description for NADP/NTN data at http://nadp.sws.uiuc.edu/documentation/notes-wk.html } \\
\text { Format description for MDN data at http://nadp.sws.uiuc.edu/dl/mdn/mdndata.pdf } \\
\text { Format description for AIRMoN data at http://nadp.sws.uiuc.edu/documentation/format_am.html }\end{array}$ \\
\hline $\begin{array}{l}\text { Database size and number of } \\
\text { records }\end{array}$ & $\begin{array}{l}\text { As of April 4, 2006: } \\
\text { - NTN: 255,886 weekly records. } \\
\text { - MDN: 24,166 weekly records. } \\
\text { - AIRMoN: } 16,056 \text { daily records. } \\
\text { Seasonal and annual aggregates are also available. }\end{array}$ \\
\hline Data format & Data are available in a variety of tabular formats, including comma-delimited and tab-delimited. \\
\hline \multicolumn{2}{|r|}{ Data quality } \\
\hline Attribute accuracy & $\begin{array}{l}\text { Estimating bias within the National Atmospheric Deposition Program and the National Trends } \\
\text { Network is discussed at http://nadp.sws.uiuc.edu/QA/bias.html. Also, see the USGS Branch of } \\
\text { Quality Systems Precipitation Chemistry Quality Assurance Project at http://bqs.usgs.gov/precip/ } \\
\text { new/frontpage_home.htm }\end{array}$ \\
\hline Completeness report & Information not provided. \\
\hline QA/QC & $\begin{array}{l}\text { Quality assurance plans, manuals, external programs, and other information are listed at } \\
\text { http://nadp.sws.uiuc.edu/QA/ } \\
\text { Several plans are listed: } \\
\text { - NADP Quality Management Plan - (PDF, } 614 \mathrm{~KB}) \text {. } \\
\text { - NTN QA Plan - (available upon request). } \\
\text { - MDN QA Plan - (PDF, 0.2 MB). } \\
\text { - AIRMoN QA Plan - (available upon request). } \\
\text { - Central Analytical Laboratory QA Plan - (PDF, } 2.77 \mathrm{MB}) \text {. } \\
\text { - Mercury (Hydrargyrum) Analytical Lab QA Plan (PDF, } 2.55 \mathrm{MB}) \text {. }\end{array}$ \\
\hline $\begin{array}{l}\text { Overall strengths and weaknesses } \\
\text { of data set }\end{array}$ & $\begin{array}{l}\text { Collected data are well suited for their intended purposes: to investigate the impacts of atmospheric } \\
\text { deposition on the productivity of managed and natural ecosystems; on the chemistry of estuarine, } \\
\text { surface and ground waters; and on biodiversity in forests, shrubs, grasslands, deserts, and alpine } \\
\text { vegetation. Researchers also use NADP MDN data to examine the role of atmospheric deposition in } \\
\text { affecting the mercury content of fish. There are no direct links between inorganic chemistry of wet } \\
\text { deposition and human health, but data may be helpful in showing how air quality is changing with } \\
\text { time. }\end{array}$ \\
\hline \multicolumn{2}{|r|}{ Metadata reference information } \\
\hline Official metadata information & Information not provided. \\
\hline Official metadata date & Information not provided. \\
\hline Official metadata standard & Information not provided. \\
\hline About this table & $\begin{array}{l}\text { This table was created using a subset of metadata defined by the EPHTN Standards and Network } \\
\text { Development Subgroup. }\end{array}$ \\
\hline Table completion date & February 2006. \\
\hline Table completed by & Paul Squillace. \\
\hline
\end{tabular}




\section{Health-Based Screening Level Database}

Health-Based Screening Levels (HBSLs) were developed for selected contaminants that do not have U.S Environmental Protection Agency (USEPA) Maximum Contaminant Levels. The purpose of the HBSL database is to provide human-health water-quality benchmarks for unregulated contaminants. Selected information for the HBSL database is provided in table 13. 
Table 13. Selected information for the Health-Based Screening Level Database.

[Interpretations within the "Overall strengths and weaknesses of data set" are in italics. ASCII, American Standard Code for Information Interchange; EPHTN, Environmental Public Health Tracking Network; HBSL, Health-Based Screening Level; IRED, Interim Reregistration Eligibility Decision; IRIS, Integrated Risk Information System; MCL, Maximum Contaminant Level; NAWQA, National Water-Quality Assessment; NJDEP, New Jersey Department of Environmental Protection; NWIS, National Water Information System; OHSU, Oregon Health \& Science University; OPP, Office of Pesticide Programs; PCB, polychlorinated biphenyl; QA/QC, quality assurance/quality control; RED, Reregistration Eligibility Decision; TRED, Tolerance Reassessment Progress and [Interim] Risk Management Decisions; URL, Uniform Resource Locator; USEPA, U.S. Environmental Protection Agency; USGS, U.S. Geological Survey; VOC, Volatile organic compound; WWW, World Wide Web]

\begin{tabular}{cc}
\hline Field name & Description for Health-Based Screening Level database \\
\hline & General information
\end{tabular}

Originator

Database abstract

Database purpose

Database WWW link/URL

Database publication date

Database contact

Full citation of published report(s)

Report contact

Beginning date

Ending date

Maintenance and update frequency

Geographic extent

Security/access clearance

Type of tracking data
USGS and Oregon Health \& Science University.

When contaminants are detected in water resources, it is important to describe what the occurrence of these contaminants may mean to human health. The USGS began an interagency pilot effort in 1998 to communicate the potential relevance of the water-quality findings of its National WaterQuality Assessment (NAWQA) Program in a human-health context. Many ground-water resources sampled by USGS are used as drinking-water sources, and water-quality conditions historically have been assessed, where appropriate, by comparing measured contaminant concentrations with drinking-water standards and guidelines. Drinking-water standards and guidelines are not available, however, for about two thirds of the contaminants measured in water by the NAWQA Program and other USGS studies. To supplement existing Federal drinking-water standards and guidelines, USGS began a collaborative project with the U.S. Environmental Protection Agency (USEPA), New Jersey Department of Environmental Protection (NJDEP), and Oregon Health \& Science University $(O H S U)$ to calculate Health-Based Screening Levels (HBSLs). HBSLs were calculated for contaminants that do not have USEPA Maximum Contaminant Levels (MCLs).

The purpose of the Health-Based Screening Level (HBSL) database is to provide human-health waterquality benchmarks for unregulated contaminants (those without USEPA MCLs). The database provides HBSLs and the supporting information used to calculate them.

HBSLs are estimates of benchmark concentrations of contaminants in water that may be of potential concern for human health. HBSLs are nonenforceable guidelines that were calculated using a consensus approach that entailed (1) standard USEPA Office of Water methodologies (equations) for establishing drinking-water guideline values for the protection of human health and (2) the most current, USEPA peer-reviewed, publicly available human-health toxicity information. As such, HBSLs are considered to be protective for humans, including sensitive groups, over a lifetime of exposure to drinking water. HBSLs do not consider all potential human exposure pathways (only drinking water ingestion), nor do they address ecological concerns.

http://water.usgs.gov/nawqa/HBSL

April 2006.

U.S. Department of the Interior, U.S. Geological Survey Patricia Toccalino 916-278-3090

ptocca@usgs.gov

A list of reports is located at http://infotrek.er.usgs.gov/traverse/f? $p=169: 5: 1694731844271184373: \because N O \because: P 5$ WHICH_SECTION: Reports

Patricia Toccalino

916-278-3090

ptocca@usgs.gov

Database originally created in 2001, but first made publicly available in April 2006.

Ongoing.

Quarterly.

National.

Open.

May be used to help prioritize contaminants considered for tracking. 
Table 13. Selected information for the Health-Based Screening Level Database.—Continued

[Interpretations within the "Overall strengths and weaknesses of data set" are in italics. ASCII, American Standard Code for Information Interchange; EPHTN, Environmental Public Health Tracking Network; HBSL, Health-Based Screening Level; IRED, Interim Reregistration Eligibility Decision; IRIS, Integrated Risk Information System; MCL, Maximum Contaminant Level; NAWQA, National Water-Quality Assessment; NJDEP, New Jersey Department of Environmental Protection; NWIS, National Water Information System; OHSU, Oregon Health \& Science University; OPP, Office of Pesticide Programs; PCB, polychlorinated biphenyl; QA/QC, quality assurance/quality control; RED, Reregistration Eligibility Decision; TRED, Tolerance Reassessment Progress and [Interim] Risk Management Decisions; URL, Uniform Resource Locator; USEPA, U.S. Environmental Protection Agency; USGS, U.S. Geological Survey; VOC, Volatile organic compound; WWW, World Wide Web]

\begin{aligned} & \hline Field name Description for Health-Based Screening Level database \\ & \hline General information-Continued \\ & \hline\end{aligned}

Intended data users

Intended data uses

Related databases

Data collection methods
Local, State, and Federal water-resource managers and others charged with protecting and managing drinking-water resources.

Concentrations of contaminants in water are compared with human-health benchmarks in screening-level assessments to provide an initial perspective on the potential relevance of detected contaminants to human health and to help prioritize further investigations. Two humanhealth benchmarks are used in USGS screening-level assessments: USEPA MCLs and HBSLs. Concentrations of regulated VOCs (those with MCLs) are compared with their MCLs and concentrations of unregulated VOCs (those without MCLs) are compared with their HBSLs, when available. These comparisons can indicate when measured concentrations may be of potential human-health concern and can provide an early indication of when contaminant concentrations in ambient water resources may warrant further study or monitoring. (http://infotrek.er.usgs.gov/

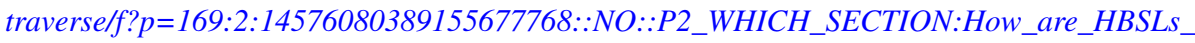
Used)

Information not provided.

Toxicity information is collected from five sources that meet four criteria: (1) data are from USEPA; (2) internally (such as USEPA) or externally peer reviewed; (3) publicly available (so anyone has access to the information); and (4) most recently available. The most recent data from the following USEPA sources are used to calculate HBSLs:

- Integrated Risk Information System (IRIS) database; Office of Research and Development (www.epa.gov/iris).

- 2004 Edition of the Drinking Water Standards and Health Advisories; Office of Water (http://www.epa.gov/waterscience/drinking/standards/dwstandards.pdf).

- Reference Dose Tracking Report; Office of Pesticide Programs (OPP) (http://npic.orst.edu/ tracking.htm). Data from this source are verified by OPP's Science Information Management Branch, Health Effects Division before using to calculate HBSLs because the report has not been updated since 1997. Other available data take precedence.

- Chemicals Evaluated for Carcinogenic Potential (2004); OPP (a copy of this report may be requested from http://www.epa.gov/pesticides/carlist/).

- Pesticide Tolerance Reassessment and Reregistration Program; OPP (http://www.epa.gov/ pesticides/reregistration/status.htm). Toxicity information are available in Reregistration Eligibility Decision (RED) documents, Interim Reregistration Eligibility Decision (IRED) documents, Reports on FQPA Tolerance Reassessment Progress and [Interim] Risk Management Decisions (TRED), and Risk Assessments in support of RED, IRED, or TRED documents.

\section{Entity and attributes}

Data elements/entities
HBSL values are available for 436 unregulated contaminants (those without USEPA MCLs) analyzed by the NAWQA Program. The database also contains supporting information about the basis upon which HBSLs were calculated and the toxicity data used for calculation. http://infotrek.er.usgs. gov/traverse/f? $p=169: 30: 14576080389155677768:: N O: R P: P 30 \_R E P O R T \_T Y P E: N O N E$ 
Table 13. Selected information for the Health-Based Screening Level Database.-Continued

[Interpretations within the "Overall strengths and weaknesses of data set" are in italics. ASCII, American Standard Code for Information Interchange; EPHTN, Environmental Public Health Tracking Network; HBSL, Health-Based Screening Level; IRED, Interim Reregistration Eligibility Decision; IRIS, Integrated Risk Information System; MCL, Maximum Contaminant Level; NAWQA, National Water-Quality Assessment; NJDEP, New Jersey Department of Environmental Protection; NWIS, National Water Information System; OHSU, Oregon Health \& Science University; OPP, Office of Pesticide Programs; PCB, polychlorinated biphenyl; QA/QC, quality assurance/quality control; RED, Reregistration Eligibility Decision; TRED, Tolerance Reassessment Progress and [Interim] Risk Management Decisions; URL, Uniform Resource Locator; USEPA, U.S. Environmental Protection Agency; USGS, U.S. Geological Survey; VOC, Volatile organic compound; WWW, World Wide Web]

\begin{tabular}{|c|c|}
\hline Field name & Description for Health-Based Screening Level database \\
\hline \multicolumn{2}{|r|}{ Entity and attributes-Continued } \\
\hline Data elements/entities-Continued & 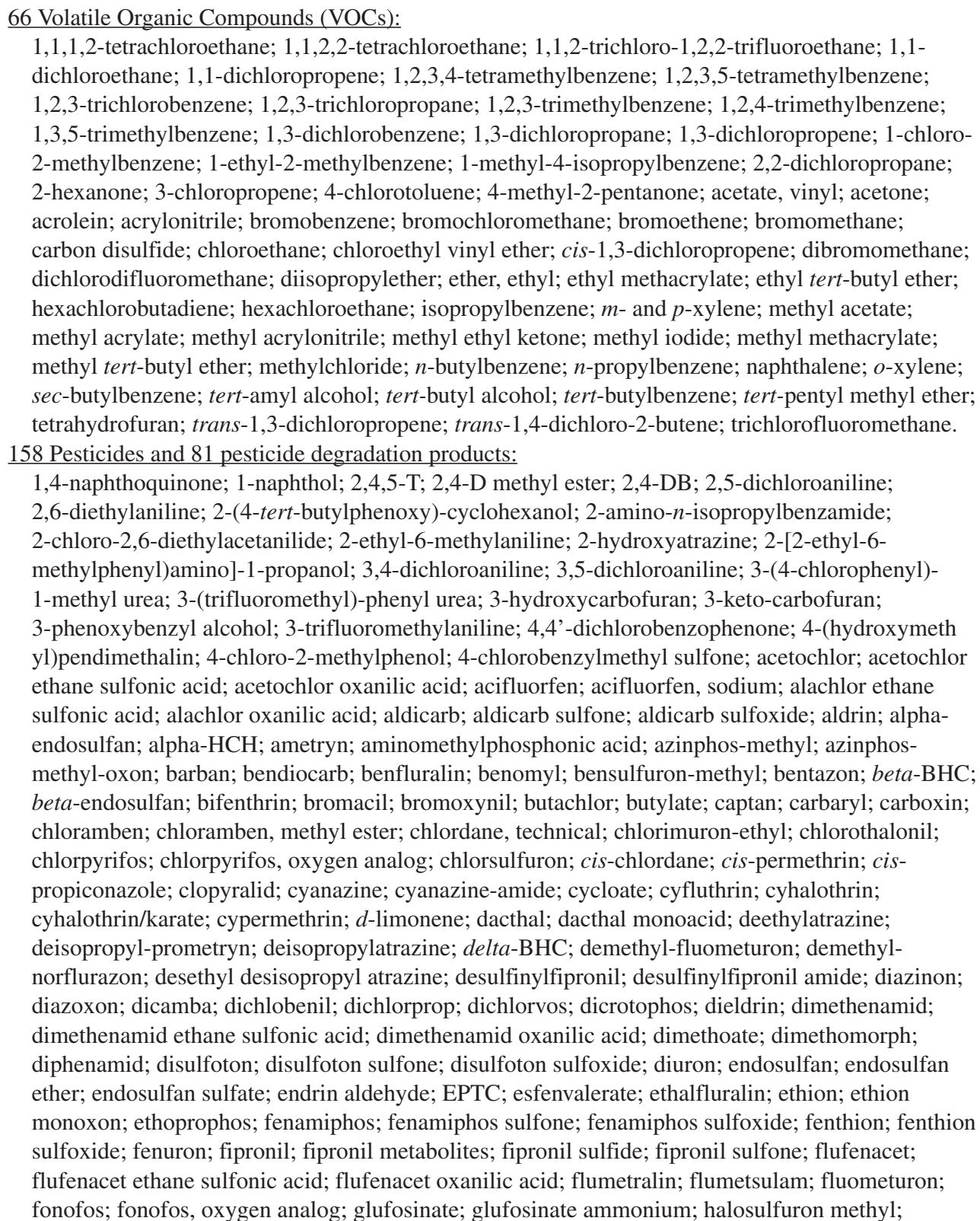 \\
\hline
\end{tabular}


Table 13. Selected information for the Health-Based Screening Level Database.-Continued

[Interpretations within the "Overall strengths and weaknesses of data set" are in italics. ASCII, American Standard Code for Information Interchange; EPHTN, Environmental Public Health Tracking Network; HBSL, Health-Based Screening Level; IRED, Interim Reregistration Eligibility Decision; IRIS, Integrated Risk Information System; MCL, Maximum Contaminant Level; NAWQA, National Water-Quality Assessment; NJDEP, New Jersey Department of Environmental Protection; NWIS, National Water Information System; OHSU, Oregon Health \& Science University; OPP, Office of Pesticide Programs; PCB, polychlorinated biphenyl; QA/QC, quality assurance/quality control; RED, Reregistration Eligibility Decision; TRED, Tolerance Reassessment Progress and [Interim] Risk Management Decisions; URL, Uniform Resource Locator; USEPA, U.S. Environmental Protection Agency; USGS, U.S. Geological Survey; VOC, Volatile organic compound; WWW, World Wide Web]

\begin{tabular}{|c|c|}
\hline Field name & Description for Health-Based Screening Level database \\
\hline & Entity and attributes-Continued \\
\hline Data elements/entities —Continued & 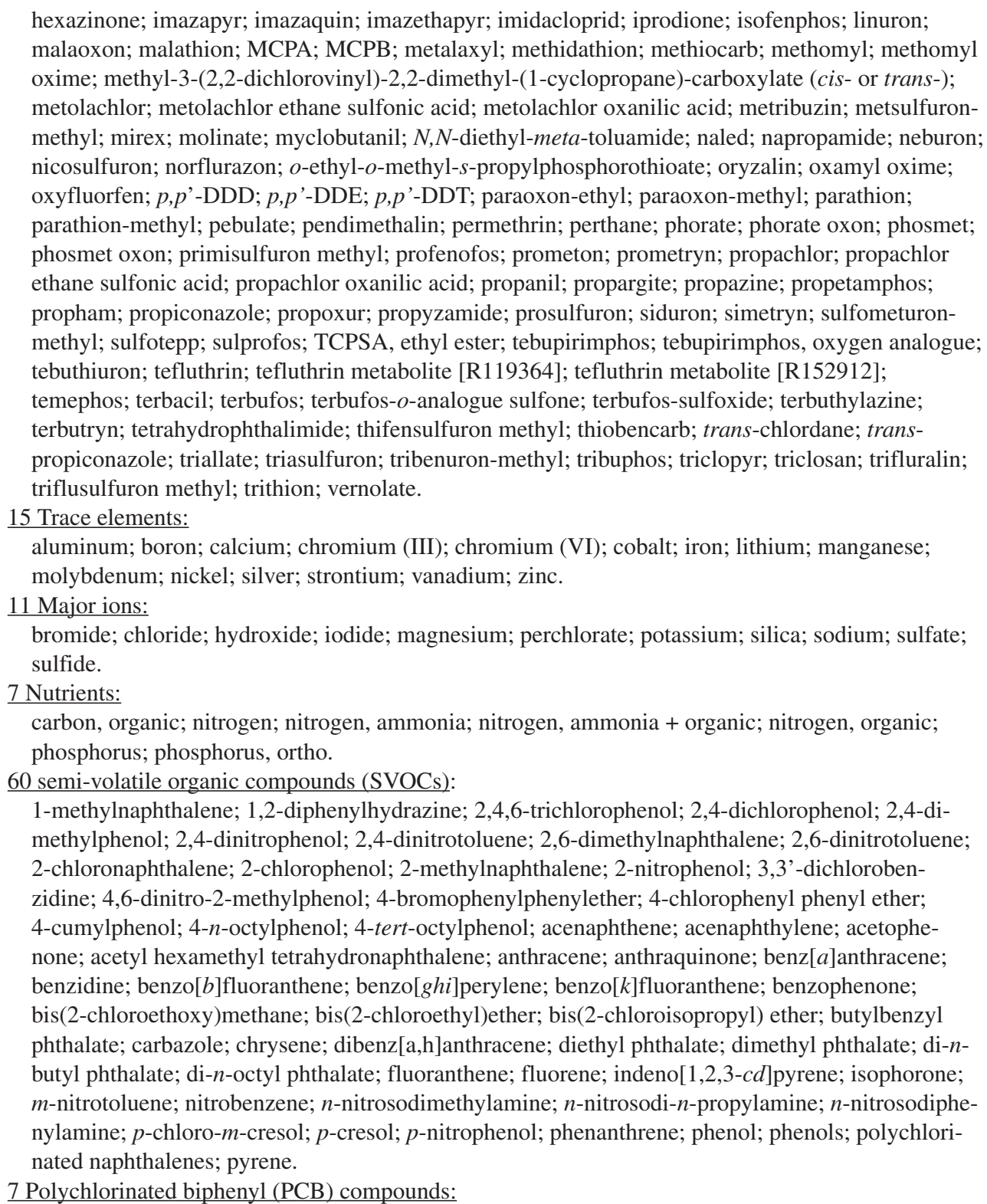 \\
\hline
\end{tabular}


Table 13. Selected information for the Health-Based Screening Level Database._Continued

[Interpretations within the "Overall strengths and weaknesses of data set" are in italics. ASCII, American Standard Code for Information Interchange; EPHTN, Environmental Public Health Tracking Network; HBSL, Health-Based Screening Level; IRED, Interim Reregistration Eligibility Decision; IRIS, Integrated Risk Information System; MCL, Maximum Contaminant Level; NAWQA, National Water-Quality Assessment; NJDEP, New Jersey Department of Environmental Protection; NWIS, National Water Information System; OHSU, Oregon Health \& Science University; OPP, Office of Pesticide Programs; PCB, polychlorinated biphenyl; QA/QC, quality assurance/quality control; RED, Reregistration Eligibility Decision; TRED, Tolerance Reassessment Progress and [Interim] Risk Management Decisions; URL, Uniform Resource Locator; USEPA, U.S. Environmental Protection Agency; USGS, U.S. Geological Survey; VOC, Volatile organic compound; WWW, World Wide Web]

\begin{tabular}{|c|c|}
\hline Field name & Description for Health-Based Screening Level database \\
\hline \multicolumn{2}{|r|}{ Entity and attributes-Continued } \\
\hline Data elements/entities - Continued & $\begin{array}{l}31 \text { Emerging contaminants such as manufacturing additives, personal care \& domestic use products, } \\
\text { and plant- or animal-derived biochemicals: } \\
\text { 17-beta-estradiol; 3-beta-coprostanol; 3-methyl-1(h)-indole; 3-tert-butyl-4-hydroxy } \\
\text { anisole; 5-methyl-1H-benzotriazole; beta-sitosterol; beta-stigmastanol; bisphenol } \\
\text { A; caffeine; camphor; cholesterol; cotinine; equilenin; estrone; ethynyl estradiol; } \\
\text { hexadydrohexamethylcyclopentabenzopyran; indole; isoborneol; isoquinoline; menthol; methyl } \\
\text { salicylate; nonylphenol, diethoxy-; octylphenol, diethoxy-; octylphenol, monoethoxy-; para- } \\
\text { nonylphenol; tri(2-butoxyethyl)phosphate; tri(2-chloroethyl)phosphate; tributyl phosphate; triethyl } \\
\text { citrate; triphenyl phosphate; tris(dichlorisopropyl)phosphate. }\end{array}$ \\
\hline $\begin{array}{l}\text { Database size and number of } \\
\text { records }\end{array}$ & About $11 \mathrm{MB}$. Information on number of records not provided. \\
\hline Data format & $\begin{array}{l}\text { Available from Web browser search; files also can be downloaded as comma separated values. } \\
\text { http://infotrek.er.usgs.gov/traverse/f? } p=169: 30: 14576080389155677768:: N O: R P: P 30 \_R E P O R T_{-} \\
\text {TYPE:NONE }\end{array}$ \\
\hline Attribute accuracy & Information not provided. \\
\hline Completeness report & Information not provided. \\
\hline QA/QC & $\begin{array}{l}\text { Two types of data quality-control procedures were performed for data in the HBSL database: (1) } \\
\text { verification of toxicity information collected from USEPA data sources and (2) verification of } \\
\text { HBSL values and the methodology and information used to calculate them. These two procedures } \\
\text { are described below. } \\
\text { 1. Toxicity information collected from USEPA data sources was entered into the HBSL database. } \\
\text { After data entry, each record was manually re-checked against its original USEPA data source. Any } \\
\text { incorrect values were corrected in the database with the correction date noted. The process was } \\
\text { then repeated to ensure that the corrections made were accurate. This quality-control procedure is } \\
\text { followed each time updates are made to the database (approximately monthly) and it is given a high } \\
\text { priority to minimize data entry errors. } \\
\text { 2. Using toxicity information collected from USEPA data sources, HBSL values were independently } \\
\text { calculated by individuals from USGS and the Oregon Health \& Science University. The proto- } \\
\text { cols (link to "How are HBSLs calculated?") and toxicity information (link to "What hierarchy of } \\
\text { toxicity information is used to calculate HBSLs?") used to calculate HBSLs are outlined in the } \\
\text { HBSL development methodology report (2003) and the revisions to the methodology (2006). The } \\
\text { independently calculated HBSL values were compared with each other and discrepancies were iter- } \\
\text { ated and resolved before the values were entered into the database. When an HBSL differs from an } \\
\text { existing USEPA Lifetime Health Advisory value and the reason for the difference is not apparent } \\
\text { (such as the same USEPA Office of Water toxicity value and calculation method are used for the } \\
\text { HBSL and Lifetime Health Advisory), USGS consults with USEPA's Office of Water to identify } \\
\text { the reason for the discrepancy. This procedure is followed each time updates to toxicity information } \\
\text { result in an update to an HBSL value. } \\
\text { See "Database maintenance and updates to information" and "Database quality-control procedures" } \\
\text { sections on this page: } h t t p: / / i n f o t r e k . e r . u s g s . g o v / t r a v e r s e / f ? p=169: 4: 14576080389155677768:: \\
N O \because: P 4 \text { WHICH_SECTION:ALL }\end{array}$ \\
\hline
\end{tabular}




\section{Summary of Selected U.S. Geological Survey Data on Domestic Well Water Quality}

Table 13. Selected information for the Health-Based Screening Level Database.-Continued

[Interpretations within the "Overall strengths and weaknesses of data set" are in italics. ASCII, American Standard Code for Information Interchange; EPHTN, Environmental Public Health Tracking Network; HBSL, Health-Based Screening Level; IRED, Interim Reregistration Eligibility Decision; IRIS, Integrated Risk Information System; MCL, Maximum Contaminant Level; NAWQA, National Water-Quality Assessment; NJDEP, New Jersey Department of Environmental Protection; NWIS, National Water Information System; OHSU, Oregon Health \& Science University; OPP, Office of Pesticide Programs; PCB, polychlorinated biphenyl; QA/QC, quality assurance/quality control; RED, Reregistration Eligibility Decision; TRED, Tolerance Reassessment Progress and [Interim] Risk Management Decisions; URL, Uniform Resource Locator; USEPA, U.S. Environmental Protection Agency; USGS, U.S. Geological Survey; VOC, Volatile organic compound; WWW, World Wide Web]

\begin{tabular}{|c|c|}
\hline Field name & Description for Health-Based Screening Level database \\
\hline \multicolumn{2}{|r|}{ Data quality-Continued } \\
\hline $\begin{array}{l}\text { Overall strengths and weaknesses of } \\
\text { data set }\end{array}$ & $\begin{array}{l}\text { - HBSLs approximately double the number of human-health benchmarks available for unregulated } \\
\text { compounds measured by NAWQA, increasing the number of compounds with benchmarks by } \\
24 \text { percent. } \\
\text { - The most recent USEPA toxicity information is used to calculate HBSLs, therefore, HBSLs provide } \\
\text { a mechanism for the timely incorporation of updated toxicity information in the interpretation of } \\
\text { water-quality data. } \\
\text { - HBSLs can be used as planning tools to help prioritize contaminants that may merit further study } \\
\text { or monitoring and to provide an early indication of contaminant concentrations of potential hu- } \\
\text { man-health concern in water resources. } \\
\text { - Because HBSLs supplement existing USEPA drinking-water standards and guidelines, they provide } \\
\text { a basis for a more comprehensive evaluation of contaminant-occurrence data in a human-health } \\
\text { context than by using USEPA benchmarks alone. Prior to the calculation of HBSLs for unregulated } \\
\text { contaminants without existing drinking-water guideline values, the ability to evaluate the human- } \\
\text { health context of their occurrence on a basis consistent with USEPA benchmarks was limited. } \\
\text { http://infotrek.er.usgs.gov/traverse/f?p=169:2:14576080389155677768::NO::P2_WHICH_ } \\
\text { SECTION:What_benefits } \\
\text { HBSLs cannot be calculated for } 241 \text { of the } 436 \text { unregulated NAWQA analytes in the database } \\
\text { because USEPA human-health toxicity information is not available. }\end{array}$ \\
\hline \multicolumn{2}{|r|}{ Metadata reference information } \\
\hline Official metadata information & http://infotrek.er.usgs.gov/docs/nawqa_www/HBSL/index_files/HBSL_metadata.txt \\
\hline Official metadata date & April 2006, updated as needed. \\
\hline Official metadata standard & Information not provided. \\
\hline About this table & Information not provided. \\
\hline Table completion date & April 2006. \\
\hline Table completed by & Patty Toccalino and Julia Norman. \\
\hline
\end{tabular}




\section{Appendix 2. Selected References for Additional Information.}

There are thousands of USGS publications online at http://water.usgs.gov/pubs/; however, the following list of references can be used as a starting point for additional information. This list of references is divided into four sections:

1. Ground-Water Flow (Aquifer Characteristics) / Surface-Water Flow

2. Water Chemistry Water-Quality Summaries for States and Nation

3. Contaminant Models (Surface Water and Ground Water)

4. Water use. 


\section{References for Ground-Water Flow (Aquifer Characteristics) / Surface-Water Flow}

Basic ground-water hydrology, by R.C. Heath (http://pubs. water.usgs.gov/wsp2220).

Bibliography of Regional Aquifer-System Analysis Program of the U. S. Geological Survey, 1978-96 (http://water.usgs. gov/ogw/rasa/html/introduction.html).

Effect of seasonal and long-term changes in stress on sources of water to wells, by T.E. Reilly and D.W. Pollock (http://pubs.usgs.gov/wsp/wsp_2445/).

Estimating areas contributing recharge to wells-Lessons from previous studies, by O.L. Franke, T.E. Reilly, D.W. Pollock, and J.W. LaBaugh (http://water.usgs.gov/ogw/pubs/ Circ1174/circ1174.pdf).

Factors affecting areas contributing recharge to wells in shallow aquifers, by T.E. Reilly and D.W. Pollack (http://pubs.usgs.gov/wsp/wsp_2412/).

Flow and storage in groundwater systems, by W.M. Alley, R.W. Healy, J.W. LaBaugh, and T.E. Reilly (http://pubs. usgs.gov/article/science/2002/vol296.html).

Ground water and surface water-A single resource, by T.C. Winter, J.W. Harvey, O.L. Franke, and W.M. Alley (http://pubs.usgs.gov/circ/circ1139/).

Ground Water Atlas of the United States (http://capp.water. usgs.gov/gwa/gwa.html).

\section{References for Water Chemistry}

Arsenic in ground water of the United States, many USGS links at http://water.usgs.gov/nawqa/trace/arsenic/index. html

A complete National Water-Quality Assessment (NAWQA) bibliography (updated April 30, 2006) is available at http://water.usgs.gov/nawqa/bib.html

Distribution of major herbicides in ground water of the United States, by J.E. Barbash, G.P. Thelin, D.W. Kolpin, and R.J. Gilliom (http://ca.water.usgs.gov/pnsp/rep/ wrir984245/).

Fifty-one Study Unit summary reports of NAWQA data for ground-water and surface-water quality collected in specific areas of the Nation (1991-2001) are available at http://water.usgs.gov/nawqa/nawqasum/.

Method, sampling, and analytical protocols for NAWQA are available at http://water.usgs.gov/nawqa/protocols/ methodprotocols.html
Occurrence of selected radionuclides in ground water used for drinking water in the United States-A targeted reconnaissance survey, 1998, by M.J. Focazio, Zoltan Szabo, T.F. Kraemer, A.H. Mullin, T.H. Barringer, and V.T. DePaul at (http://pubs.usgs.gov/wri/wri004273/).

The quality of our Nation's waters-Nutrients and pesticides (http://pubs.usgs.gov/circ/circ1225/).

The quality of our Nation's waters-Pesticides in the Nation's streams and ground water, 1992-2001, by R.J. Gilliom, J.E. Barbash, C.G. Crawford, P.A. Hamilton, J.D. Martin, N. Nakagaki, L.H. Nowell, J.C. Scott, P.E. Stackelberg, G.P. Thelin, and D.M. Wolock (http://pubs.usgs.gov/ circ/2005/1291/).

The quality of our Nation's waters-Volatile organic compounds in the Nation's ground water and drinkingwater supply wells, by J.S. Zogorski, J.M. Carter, Tamara Ivahnenko, W.W. Lapham, M.J. Moran, B.L. Rowe, P.J. Squillace, and P.L. Toccalino (http://pubs.usgs.gov/circ/ circ1292/).

A retrospective analysis on the occurrence of arsenic in ground-water resources of the United States and limitations in drinking-water-supply characterizations, by M.J. Focazio, A.H. Welch, S.A. Watkins, D.R. Helsel, and M.A. Horn (http://water.usgs.gov/nawqa/trace/pubs/wrir-99-4279/).

Study and interpretation of the chemical characteristics of natural water, by J.D. Hem (http://pubs.usgs.gov/wsp/ wsp2254/).

Trace-element concentrations in streambed sediment across the conterminous United States, by K.C. Rice, Environmental Science and Technology, v. 33 no. 15, p. 2,499-2,504.

Water quality in the Nation's streams and aquifers-Overview of selected findings, 1991-2001, by P.A. Hamilton, T.L. Miller, and D.N. Myers (http://pubs.usgs.gov/ circ/2004/1265/).

\section{References for Contaminant Models (Surface Water and Ground Water)}

Development and application of watershed regressions for pesticides (WARP) for estimating atrazine concentration distributions in streams, by S.J. Larson, C.G. Crawford, and R.J. Gilliom (http://pubs.usgs.gov/wri/wri034047/ wrir034047.pdf).

Mapping arsenic in groundwater, by Sarah Ryker (http://www. agiweb.org/geotimes/nov01/feature_Asmap.html). 
Modeling of surface-water quality using the SPARROW approach is available at http://water.usgs.gov/nawqa/ sparrow/.

A national model for assessing the susceptibility of surfacewater supplies to source-area contamination, by M.J. Focazio, R.A. Smith, R.B. Alexander, and G.E. Schwarz (http://water.usgs.gov/nawqa/sparrow/drink/dwater.html).

Probability of nitrate contamination of recently recharged groundwaters in the conterminous United States, by B.T. Nolan, K.J. Hitt, and B.C. Ruddy, Environmental Science and Technology, v. 36, no. 10, p. 2,138-2,145 (http://water.usgs.gov/nawqa/nutrients/pubs/est_v36_nol0/ est_v36_no10.pdf). This article supersedes Environmental Science and Technology, v. 31, no. 8; Water Conditioning and Purification, v. 39, no. 12; and USGS Fact Sheet FS-092-96.

Summary of selected computer programs produced by the U.S. Geological Survey for simulation of ground-water flow and quality - 1994, by C.A. Appel and T.E. Reilly (http:// water.usgs.gov/ogw/pubs/Circ1104/).

\section{References for Water Use}

Estimated use of water in the United States in 2000, by S.S. Hutson, N.L. Barber, J.F. Kenny, K.S. Linsey, D.S. Lumia, and M.A. Maupin (http://pubs.usgs.gov/ circ/2004/circ1268/).

Estimated withdrawals from principal aquifers in the United States, 2000, by M.A. Maupin and N.L. Barber (http://pubs. usgs.gov/circ/2005/1279/).

Water availability for the western United States-Key scientific challenges, by M.T. Anderson and L.H. Woosley, Jr. (http://pubs.usgs.gov/circ/2005/circ1261/). 
Manuscript approved for publication, September 18, 2007.

Prepared by the Helena Publishing Service Center.

For more information concerning the research in this report, contact: U.S. Geological Survey

Director, South Dakota Water Science Center 1608 Mountain View Road

Rapid City, SD 57702

http://sd.water.usgs.gov/ 
